PNL-3060

UC-70

\title{
Annual Report on the Development and Characterization of Solidified Forms for High-Level Wastes: 1978
}

W. A. Ross

J. E. Mendel

December 1979

Prepared for the U.S. Department of Energy under Contract EY-76-C-06-1830

Pacific Northwest Laboratory Operated for the U.S. Department of Energy by Battelle Memorial Institute 


\title{
NOTICE
}

This report was prepared as an account of work sponsored by the United States Government. Neither the United States nor the Department of Energy, nor any of their employees, nor any of their contractors, subcontractors, or their employees, makes any warranty, express or implied, or assumes any legal liability or responsibility for the accuracy, completeness or usefulness of any information, apparatus, product or process disclosed, or represents that its use would not infringe privately owned rights.

The views, opinions and conclusions contained in this report are those of the contractor and do not necessarily represent those of the United States Government or the United States Department of Energy.

\author{
PACIFIC NORTHWEST LABORATORY \\ operated by \\ BATTELLE \\ for the \\ UNITED STATES DEPARTMENT OF ENERGY \\ Under Contract EY-76-C-06-1830
}

\begin{tabular}{|c|c|}
\hline \multicolumn{2}{|c|}{$\begin{array}{l}\text { Printed in the United States of America } \\
\text { Available from } \\
\text { National Technical Information Service } \\
\text { United States Department of Commerce } \\
5285 \text { Port Royal Road } \\
\text { Springfield, Virginia } 22151\end{array}$} \\
\hline e: Printed Cop! & $\because$ Microfiche $\$ 3 . \alpha$ \\
\hline -Pages & $\begin{array}{c}\text { NTIS } \\
\text { Selling Price }\end{array}$ \\
\hline $001-025$ & $\$ 4.00$ \\
\hline $026-050$ & $\$ 4.50$ \\
\hline $051-075$ & $\$ 5.25$ \\
\hline $076-100$ & $\$ 6.00$ \\
\hline $101-125$ & $\$ 6.50$ \\
\hline $126-150$ & 57.25 \\
\hline $151-175$ & $\$ 8.00$ \\
\hline $176-200$ & $\$ 9.00$ \\
\hline $201-225$ & 59.25 \\
\hline $226-250$ & $\$ 9.50$ \\
\hline $251-275$ & $\$ 10.75$ \\
\hline $276-300$ & $\$ 11.00$ \\
\hline
\end{tabular}


ANNUAL REPORT ON THE DEVELOPMENT AND CHARACTERIZATION OF SOLIDIFIED FORMS FOR HIGH-LEVEL WASTES: 1978

W. A. Ross and J. E. Mendel, Editors

December 1979

Prepared for the U.S. Department of Energy under Contract EY-76-C-06-1830

Pacific Northwest Laboratory Richland, Washington 99352

DOE. Fichland, WA 


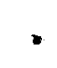

$\checkmark$ 
SUMMARY

J. E. Mende 1

Development and characterization of solidified high-level waste forms--a major program at the Pacific Northwest Laboratory (PNL) for several years-- is continuing. These efforts are directed at determining both process properties and long-term behaviors of various solidified high-level waste forms in aqueous, thermal, and radiation environments. Glass waste forms for defense wastes were emphasized in 1978, and investigations of the long-term behavior of powerreactor waste glasses were continued. The characterization of alternative waste forms, including crystalline forms, coated particles and metal matrices, is being done by the same techniques that are being used for waste glasses.

Waste form specifications are not yet defined. The goal of waste form characterization is to measure the important properties and potential reactions of candidate waste forms. Judgments on the acceptability of the values obtained in measurements on the different candidate waste forms will come from analyses of the tulal multibarrier waste management system. Such an analysis is included as the Appendix, which compares the leaching behavior of waste forms with the known behavior of natural ores. The results to date indicate that the isolation achieved in a geologic repository is relatively insensitive to leach rate over a wide range.

A new and promising computer-based approach to waste glass development was initiated at PNL this year. The objective is to develop a model of glass properties over broad compositional ranges so that, given a particular waste for vitrification, the most promising compositional field can be immediately identified. Two studies exploring the new technique were completed and a third was started. The waste glass properties that were measured as a function of composition were melt viscosity, melt electrical conductivity, devitrification, and chemical durability. The alkali metals were found to have the greatest effect upon glass properties. When expressed as a function of mole-percent, no difference could be found in the effects of sodium, potassium and lithium. Titanium caused a slight decrease in viscosity and a significant increase in chemical durability in acidic solutions (pH-4). Aluminum, nickel and iron were all found to increase the formation of nickel-ferrite spinel crystals in the glass.

The development of glass waste forms is nearing completion, although characterization of long-term behaviors continues. Laboratory development and characterization of alternative or advanced waste forms that can potentially offer further incremental improvements in safety are receiving increased emphasis. Four multibarrier advanced waste forms were produced on a oneliter scale with simulated waste and were then characterized. Glass marbles encapsulated in a vacuum-cast lead alloy provided improved inertness with a minimal increase in technological complexity. Supercalcine spheres exhibited excellent inertness when coated with pyrolytic carbon and alumina and put in a metal matrix, but the processing requirements are quite complex.

Canister development efforts emphasized confirmation of computer codes by means of experimental data. The computer codes predict stress in the canister wall and in the contained glass. Heat transfer codes applied to canisters of waste glass also correlated well with empirical data. 
During 1978 the scope of the leaching studies at PNL continued to broaden. We are now attempting to not only define initial leach rates for various waste forms in realistic environments, but also to project what they are likely to be well beyond experimentally verifiable times. We are also attempting to define what a given leach rate means in terms of geologic isolation.

The results of tests on simulated and actual high-level waste glasses continue to suggest that thermal devitrification has a relatively small effect upon mechanical and chemical durabilities. Although the identity of the individual crystalline phases appearing upon devitrification of waste glasses is highly dependent upon the glass composition, there is a general similarity in devitrification kinetics because all the waste glasses have been formulated to have a viscosity of less than 200 poise at $1050^{\circ} \mathrm{C}$. Formation of large crystals has been observed to cause microcracking, but this can be avoided in all of the glasses by maintaining storage temperatures at below $650^{\circ} \mathrm{C}$.

Tests on the effects radiation has upon waste forms also continue to show changes to be relatively insignificant. The effects caused by decay of actinides can be estimated to saturate at near $10^{19}$ alpha-events $/ \mathrm{cm}^{3}$ in homogeneous solids. Actually, in solidified waste forms the effects are usually observed to saturate in the range 2 to $5 \times 10^{18}$ alpha-events $/ \mathrm{cm}^{3}$. Microcracking has been observed around certain crystals as radiation causes amorphization and swelling of the crystals. However, no deleterious macro-effects on the waste forms containing the crystals have been observed.

A significant portion of the characterization measurements are now being made on glass containing simulated nonradioactive waste that is made in engineering-scale equipment. Certain homogeneity problems will be difficult to detect until fully radioactive runs are made. In particular, insolubles such as $\mathrm{CeO}_{2}$ or spinel crystals can form viscous sludges in the bottom of continuous glass melters. Samples of such sludges were characterized; formulations for their elimination are being developed.

As other waste forms are developed to the point that they can be produced in engineeringscale equipment, characterization of those products will also become an important part of the program. 


\section{ACKNOWLEDGEMENTS}

The authors wish to acknowledge the substantial editing and production assistance provided by M. H. Henry throughout this publication effort. We also gratefully acknowledge the text processing services of K. L. Feuerbacher. 


\section{-}

-

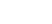




\section{CONTENTS}

SUMMARY

ACKNOWLEDGEMENTS

I. INTRODUCTION .

II. WASTE COMPOSITIONS .

III. WASTE FORM SPECIFICATIONS

THE ENGINEERED BARRIER SYSTEM

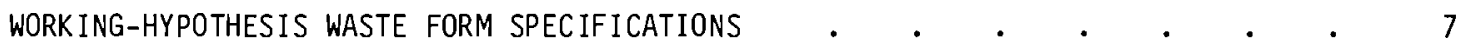

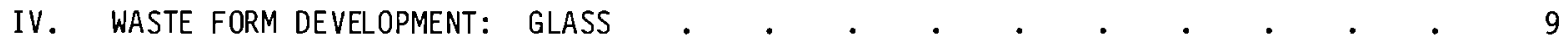

ONE-AT-A-TIME VARIATION STUDY ON DEFENSE WASTE GLASSES $\quad$ • $\quad$ • $\quad$ • $\quad$ • 9

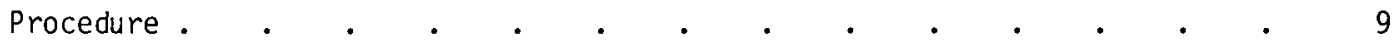

Results . . . . . . . . . . . . . . . . . . . . . 9

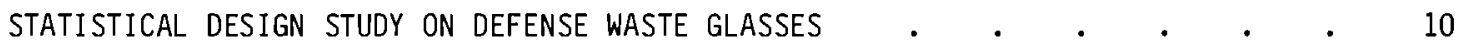

ELEVEN-COMPONENT MIXTURE DESIGN STUDY ON GENERIC WASTE GLASSES • • • • • 16

FULL GENERIC STUDY •

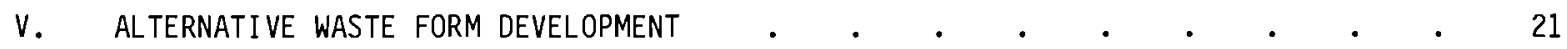

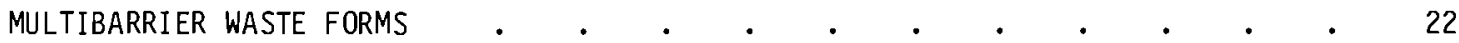

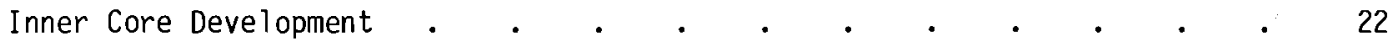

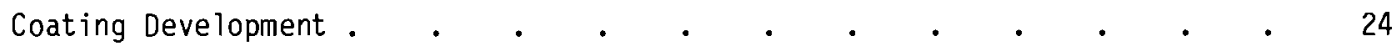

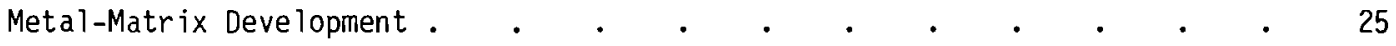

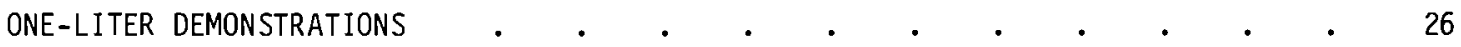

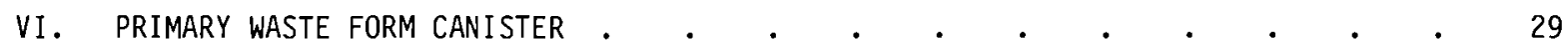

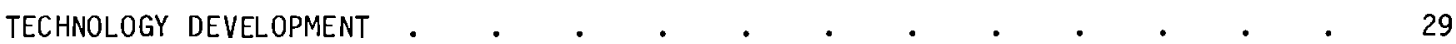

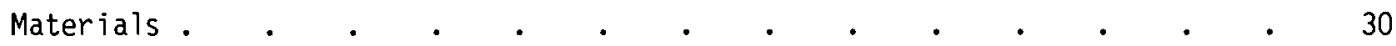

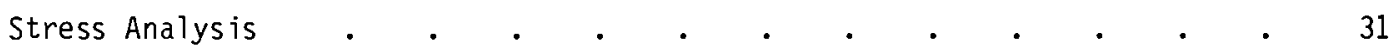

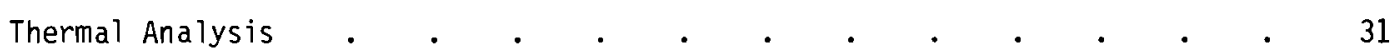

FULL-SCALE TESTING •

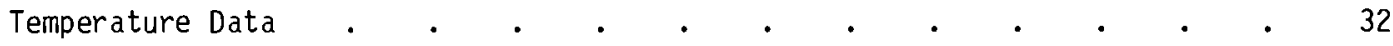

Canister Corrosion and Deformation .

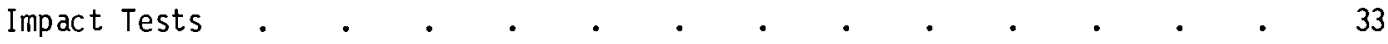

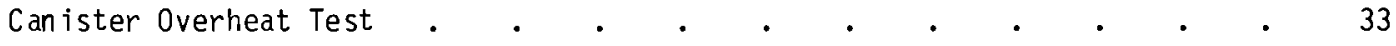




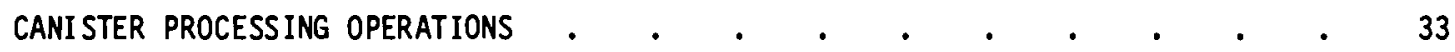

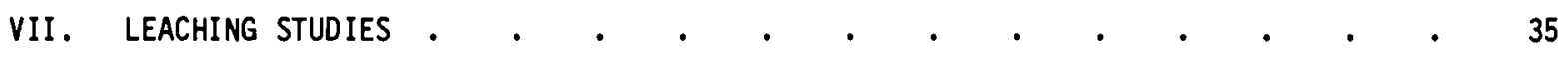

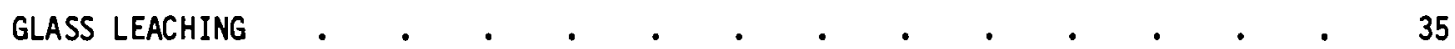

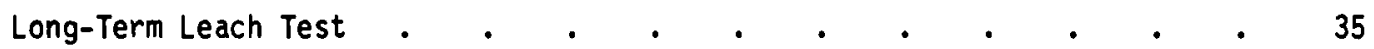

Hydrothermal Studies . . . . . . . . . . . . 37

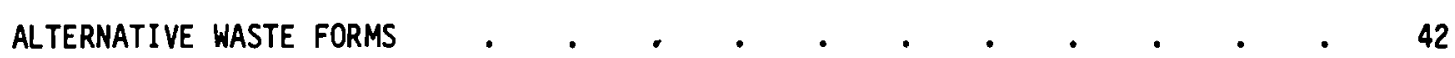

Supercalcine . . . . . . . . . . . . . . 42

Oak Ridge National Laboratory Cermet . . . . . . . . . 43

SPENT FUEL

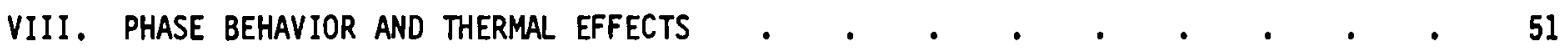

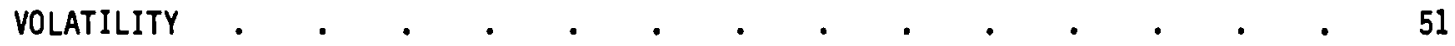

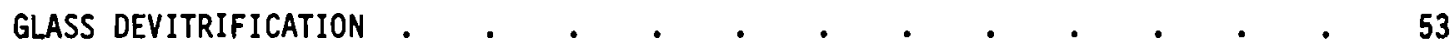

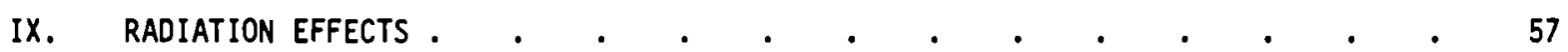

GLASSES • • • • •

CRYSTALLINE WASTE SOLIDS $. \quad . \quad . \quad . \quad . \quad . \quad . \quad . \quad . \quad . \quad .60$

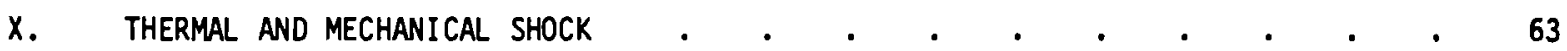

XI. QUALITY VERIFICATION

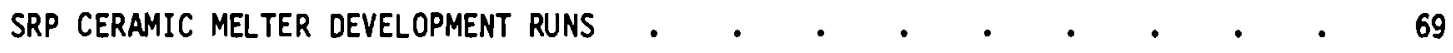

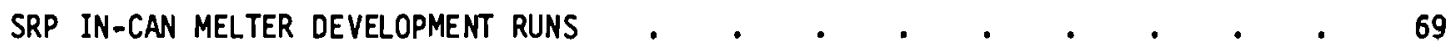

WSEP GLASS CHARACTERIZATION .

REFERENCES • • •

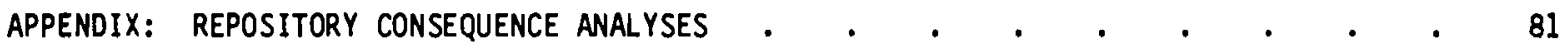




\section{FIGURES}

III.1 Engineered Barrier Concept for Waste Isolation . . . . . . . . . 6

IV.1 Effects of Components on Soxhlet Leach Rate $\quad . \quad$. $\quad . \quad$. $\quad . \quad$ - $\quad 12$

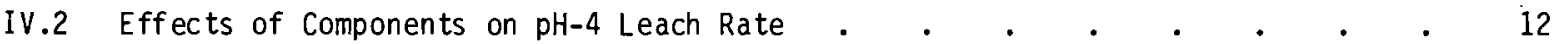

IV.3 Effects of Components on Temperature at Which Viscosity $=100$ Poise $. \quad . \quad . \quad . \quad . \quad . \quad . \quad . \quad . \quad . \quad . \quad . \quad 13$

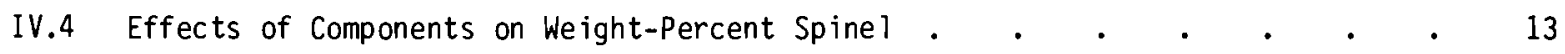

IV.5 Effect of SRP/TDS Study Components on Predicted Weight-Percent Spinel

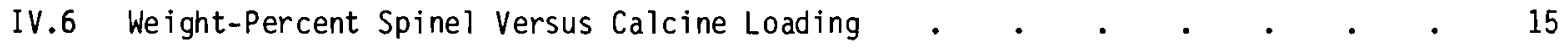

IV.7 Log Viscosity Versus Calcine Loading • • • • • • • • • • • • $\quad$ • 15

IV.8 Soxhlet Leach Rate Versus Change in Component
from Centroid

IV.9 Log Viscosity Versus Change in Component from Centroid • • • • • $\quad$ • 17

IV.10 Log Conductivity Versus Change in Component from Centroid • • • • • 18

IV.11 Log Volatility Versus Change in Component from Centroid . $\quad$ • $\quad$ - $\quad$ • 18

V.1 Multibarrier Concept for Isolating High-Level Waste . • . • . • . $\quad$ - 21

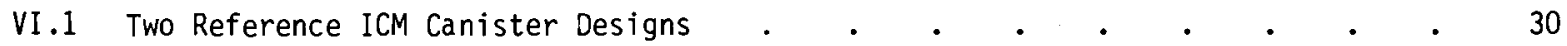

VI.2 Radial Temperature Profiles of a $30-\mathrm{cm}-\mathrm{dia}$ Ceramic

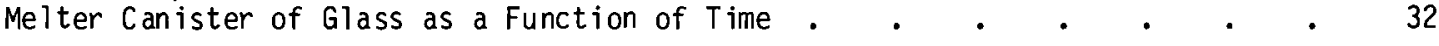

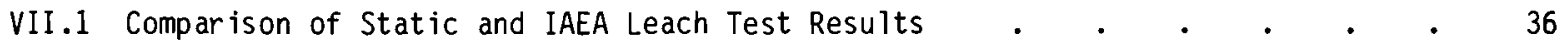

VII.2 Leach Rates of 76-68 Glass Based on Cesium as a Function

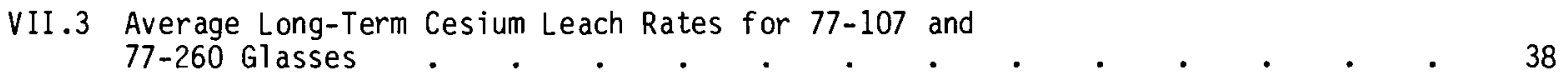

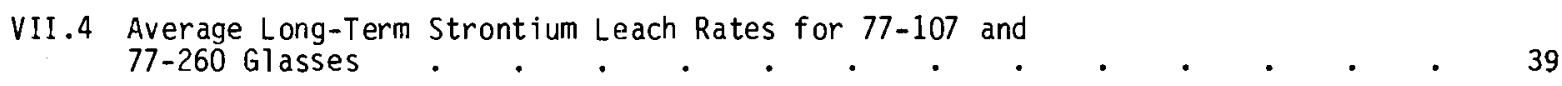

VII.5 Long-Term Leach Test Results in Brine, Bicarbonate and
Deionized Waters . $. \quad . \quad . \quad . \quad . \quad . \quad . \quad . \quad . \quad . \quad 40$

VII.6 Long-Term Leach Rates in $\mathrm{CaCl}_{2}$ and $\mathrm{NaCl}$ Solutions $\quad . \quad$. $\quad . \quad$. $\quad . \quad 41$

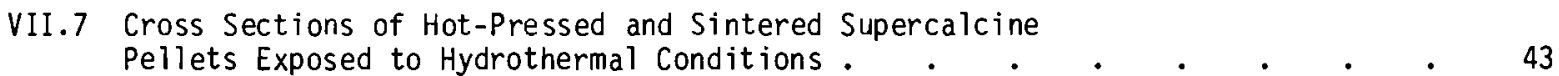

VII.8 Leach Rate of Spent Fuels Based on Release of ${ }^{137} \mathrm{Cs}$ in Deionized Water at $25^{\circ} \mathrm{C}$ with Burnups of $9.0,28.0$ and $54.5 \mathrm{MWd} / \mathrm{kgU}$. $. \quad . \quad . \quad . \quad . \quad$.

VII.9 Leach Rate of Spent Fuels Based on Release of $2398240 \mathrm{Pu}$ in Deionized Water at $25^{\circ} \mathrm{C}$ with Burnups of $9.0,28.0$ and 54.5 $\mathrm{MWd} / \mathrm{kgU}$. 
VII.10 Leach Rate of Spent Fuels Based on the Release of Uranium in Deionized Water at $250 \mathrm{C}$

VII.11 Leach Rate of Spent LWR Fuels Based on the Release of $244 \mathrm{Cm}$ in Deionized Water at $25^{\circ} \mathrm{C}$ with Burnups of $9.0,28.0$ and $54.5 \mathrm{MWd} / \mathrm{kgU}$.

VII.12 Leach Rate of 54.5-MWd/kgU Spent LWR Fuel in Deionized Water at $25^{\circ} \mathrm{C}$

VIII.1 Fraction of Cesium Lost after $4 \mathrm{~h}$ at Respective Temperatures from a Thin $(\sim 1-\mathrm{cm})$ Sample of Material

VIII.2 Percent-Crystallinity Curves as a Function of Temperature

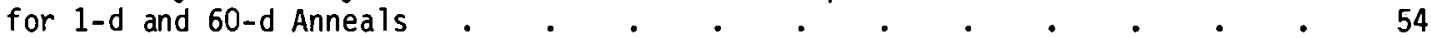

VIII.3 Time-Temperature Transformation (5\%) Curves for Waste Glasses $72-68$ and $76-68$

IX.1 Change in Density of Waste Materials as a Function of Alpha-Radiation Dose

IX.2 Alpha-Radiograph Showing Concentration of Am Dopant

IX.3 Initial Microstructures in the Three Waste Glass Forms Investigated and Alpha-Autoradiograph with Corresponding Optical Images Before and After Micro-Fracturing

IX.4 Volume Changes for Crystalline Phases as a Function of

Accumulated $\alpha$-Damage

X.1 Canister CM-1, with Sector Removed from Side

X.2 Sieve Analys is Data for Two 0.61-m Canisters--0ne As-Poured and One After Impact Testing

XI.1 Process and Product Variables for Canister \#52, Which Was

Filled in Runs SRP-4 through SRP-7

XI.2 Micrograph of Glass Sample from Canister \#52

$15 \mathrm{~cm}$ Above Bottom

XI.3 Micrograph of Glass Sample from Canister \#52

$61 \mathrm{~cm}$ Above Bottom

XI.4 Micrograph of Glass Sample from Canister \#52

XI.5 Micrograph of Glass Sample from Canister \#52 $152 \mathrm{~cm}$ Above Bottom

XI.6 Leach Rate Based on ${ }^{137}$ Cs Release of Borosilicate Glass Vitrified During WSEP Run SS-12 After Storage Periods Indicated

A.1 Potential Maximum Dose Rate Versus Delay in Release Initiation for Generic Site

A.2 Potential Maximum Dose Rate Versus Release Rate

for Generic Site.

A.3 Potential Maximum Dose Rate Versus Release Rate for a Reference Salt Site 
II.1 Analys is of Washed Waste Sludges at Savannah River . . . . . . . 3

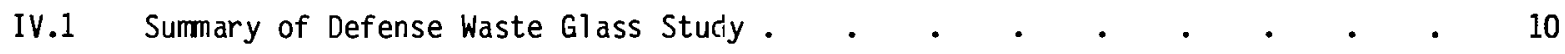

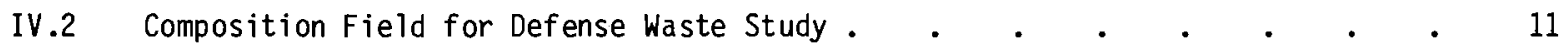

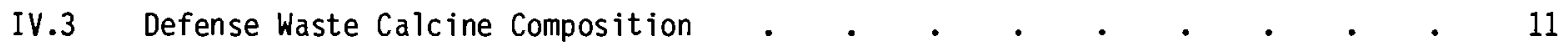

IV.4 Composition Field for Eleven-Component Generic Study . . . . . 16

V.1 Crystal Chemical Roles of Waste Ions . . . . . . . . . . . . . 22

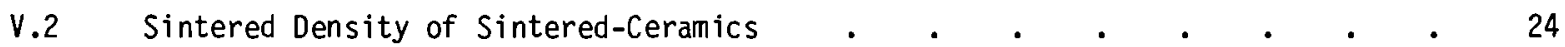

VII.1 Latest Long-Term Leach Rates of Four Simulated HLW Glasses • • . 35

VII.2 Soxhlet Leach Data for Standard Glasses After One-Year

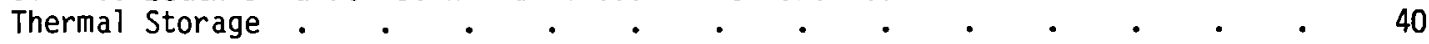

VII.3 Hydrothermal Leach Test Results for 76-68 Glass . . . . . . . . 41

VII.4 Leachability Results of Supercalcine Autoclave Tests _ . . . . . . 42

VII.5 Results of Leach Tests on ORNL Cermet . . . . . . . . . . . . 44

VIII.1 Principal Crystalline Phases Observed in Devritrified Waste Glasses 72-68, 76-68 and 77-260 $\cdot$ •

X.1 Sizing Data $(+44 \mu \mathrm{m})$ for As-Filled Canisters . . . . . . . . . . 65

XI.1 Product Characterization for SRP-ICM Run with 61-cm Can . . . . . 73

XI.2 Chemical Analyses for SRP-ICM Run with 61-cm Can . . . . . . . . 73

A.1 Nuclide Inventories for Ore Bodies and Reference Repository . . . . . 86

A.2 System Parameters for Ore Bodies and Reference Repository . . . . 86 
. 


\section{INTRODUCTION}

W. A. Ross

In conjunction with the Department of Energy (DOE), the Pacific Northwest Laboratory (PNL), operated by Battelle Memorial Institute, continues to develop technology for solidification and disposal of high-level radioactive wastes (HLW). This is the third annual report prepared to summarize PNL research and development activities on waste forms.

The first and second annual reports (Mendel et al. 1977, Ross et al. 1978) were prepared as a result of the Program $\mathrm{Plan}$ for the Comprehensive Characterization of Solidified High-Level Wastes issued in late 1975 (Mendel et al. 1975). These first two reports were focused primarily upon the characterization of commercial waste glasses; data from them and from this report have been compiled in a comprehensive report (Mendel 1978).

This year's annual report has been expanded to include all waste materials, including defense waste glasses, spent fuel, and alternative waste forms-- in addition to HLW glasses; the report includes developmental as well as characterization results. The annual's primary source of information is the High-Level Waste Immobilization Program (HLWIP). In addition to laboratory-scale waste form development and characterization, the HLWIP includes engineering-scale development (on both a nonradioactive and radioactive basis) of processes for producing solidified radioactive waste forms. Progress in the HLWIP is reported in quarterly reports. The most recent report, which includes a listing of all previous reports, is PNL-3050-2 (MCElroy et al. 1979e).

A large amount of leaching work on waste forms in geologic environments is being done at PNL in a related program--the Waste Isolation Safety Assessment Program (WISAP)--which is sponsored by DOE's Office of Nuclear Waste Isolation (ONWI). Since the leaching work in the HLWIP is coordinated closely with that in the WISAP, the latter leaching program is also described briefly in this report. Progress in the WISAP is also reported quarterly, with the most recent report being PNL-2885-3 (Brandstetter et al. 1979).

Detailed evaluations have continued to emphasize materials development, leaching behavior, thermal effects, radiation effects, mechanical comparisons, and application to full-scale systems. With the expanded scope of this report and the desire to keep it of readable size (and therefore usable), we have attempted to summarize as much as possible. References are supplied to assist in the location of additional information. Also, each section's authors and contributors are noted accordingly. 
.

. 


\section{WASTE COMPOSITIONS}

J. L. Swanson

Flowsheets are being developed for the final disposal of the defense HLW currently stored in neutralized form at Savannah River and Hanford. Since the volume of these wastes is very 1 arge and since the activity (except for ${ }^{137} \mathrm{Cs}$ ) is concentrated in the sludge that formed after neutralization, the $\mathrm{pl}$ an is to separate the radioactive sludge from the supernate before proceeding with immobilization. This will greatly reduce the volume of radioactive waste that must be immobilized. The supernate can be treated as an extremely low-level waste after the ${ }^{137} \mathrm{Cs}$, residual ${ }^{90} \mathrm{Sr}$ and plutonium ions are removed. These materials are then combined with the washed sludge for immobilization. Final selection of the waste form for immobilization of the defense wastes at Savannah River is scheduled for about 1982.

The waste form that is selected will have to be adaptable enough to accommodate a wide variety of waste compositions. As shown in Table II.1., the sludge from each waste tank has a different composition, though iron and aluminum are always major constituents.

Commercial waste compositions were detailed in last year's annual report, which also contained the glass code explanation (Ross et al. 1978).

TABLE II.1. Analysis of Washed Waste Sludges at Savannah River(a)

\begin{tabular}{|c|c|c|c|c|c|c|c|c|c|c|}
\hline \multirow{2}{*}{$\begin{array}{l}\text { Metal } \\
\text { Ion }\end{array}$} & \multicolumn{10}{|c|}{ Sample Composition, wt\% } \\
\hline & 4,6 & 5 & 5 & 7 & 12 & 13 & 13 & 15 & 15 & 16 \\
\hline $\mathrm{Fe}$ & 33.0 & 29.0 & 28.0 & 8.9 & 4.5 & 26.0 & 28.0 & 5.3 & 3.1 & 14.0 \\
\hline Al & 2.3 & 1.6 & 1.5 & 2.5 & 30.0 & 8.7 & 7.1 & 19.0 & 34.0 & 17.0 \\
\hline $\mathrm{Mn}$ & 2.0 & 5.8 & 11.0 & 2.2 & 1.7 & 7.8 & 8.8 & 2.4 & 2.3 & 2.6 \\
\hline U & 9.2 & 11.0 & 15.0 & 3.3 & (b) & 4.2 & 4.0 & 3.8 & 0.9 & 4.5 \\
\hline $\mathrm{Na}$ & 3.0 & 5.7 & 6.1 & 2.8 & 1.0 & 2.6 & 3.1 & 2.4 & 1.2 & 2.2 \\
\hline $\mathrm{Ca}$ & 2.3 & 0.9 & 0.6 & 0.8 & 2.1 & 1.8 & 2.3 & 0.5 & 0.2 & 2.9 \\
\hline $\mathrm{Hg}$ & 0.6 & 0.1 & 0.1 & 0.06 & 1.1 & 2.3 & 2.1 & 2.5 & 0.9 & 2.8 \\
\hline $\mathrm{Ni}$ & 6.3 & 6.3 & 5.1 & 2.1 & 0.5 & 0.4 & 0.5 & 0.7 & 0.5 & 0.3 \\
\hline C & -- & & & 17.0 & & & & & & \\
\hline Si & -- & & & 3.2 & & & & & & \\
\hline $\mathrm{Bi}$ & -- & & & & & & & & & \\
\hline \multicolumn{11}{|c|}{ Anions } \\
\hline $\mathrm{NO}_{3}$ & 0.1 & 1.2 & 3.0 & 1.2 & 0.4 & 0.3 & 0.5 & 0.2 & 5.0 & 0.3 \\
\hline $\mathrm{SO}_{4}$ & 0.5 & 0.5 & & & 0.5 & 0.5 & & 0.5 & & 0.5 \\
\hline $\mathrm{Cl}^{-}$ & & & & 2.0 & & & 1.0 & & & \\
\hline
\end{tabular}

(a) Ref. DP-1399 and DP-1441

(b) No data 


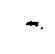




\section{WASTE FORM SPECIFICATIONS}

\section{J. E. Mende 1}

The goal of the HLWIP is to immobilize high-level radioactive wastes in the form of stable, inert solids. Detailed specifications for the properties that the solidified waste forms must possess to qualify as being "stable" and "inert" have not yet fully evolved. The Nuclear Regulatory Commission (NRC) is expected to provide guidance in this area late in 1979.

The solidified waste form is an integral part of much of the waste management system, including: 1) waste immobilization processing, 2) inter im surface storage, 3) transportation, and 4) deep geologic disposal. The requirements of deep geologic isolation are dominant for two major reasons. First, most of the lifetime of the waste forms will be spent in geologic disposal, where both surveillance and remedial action are difficult. Second, waste form requirements may differ depending up on the type of rock in which the geologic repository is located--i.e., certain waste form specifications could be site-specific. Although deep geologic isolation demands much attention, the other parts of the system also place significant requirements upon the properties of the waste form and must also be given their due consideration.

\section{THE ENGINEERED BARRIER SYSTEM}

The deep geologic disposal system utilizes a system of multiple barriers to obtain the highest assurance of reliability. The stable, inert solidified waste form is only one component of the system. All of the components of the system are shown in Figure III.1. A feature of the engineered barrier system is the possibility of adding barriers. For a given repository, fewer or more barriers than those shown here may be used. Briefly, the functions of the engineered barrier system components are as follows:

- Overburden - A repository depth of $600 \mathrm{~m}$ or more assures that any water which might possibly be contaminated by repository contact will have such a lengthy, timeconsuming path to travel before reaching the biosphere that the radionuclides will either be adsorbed on the soil or will decay to harmless levels.

- Near-Field Geology - The repository will be located within a deep geologic formation specially selected for its dryness and impermeability.

- Specially Designed Engineered Barriers (optional) - Additional engineered barriers can be incorporated into the repository design for special purposes. For example, materials that will swell when contacted with water may be used to prevent water from reaching the solidified waste forms, and materials that will adsorb radionuclides from water (should leaching occur) may also be included.

- Overpack (optional) - Another type of engineered barrier--the overpack is usually considered to be a secondary canister. The overpack can be designed to be an absolute barrier for finite periods in the repository. For instance, design lifetimes of $500 \mathrm{yr}$ are feasible and would permit the ${ }^{90} \mathrm{Sr}$ and ${ }^{137} \mathrm{Cs}$ in the waste to decay to harmless levels. 

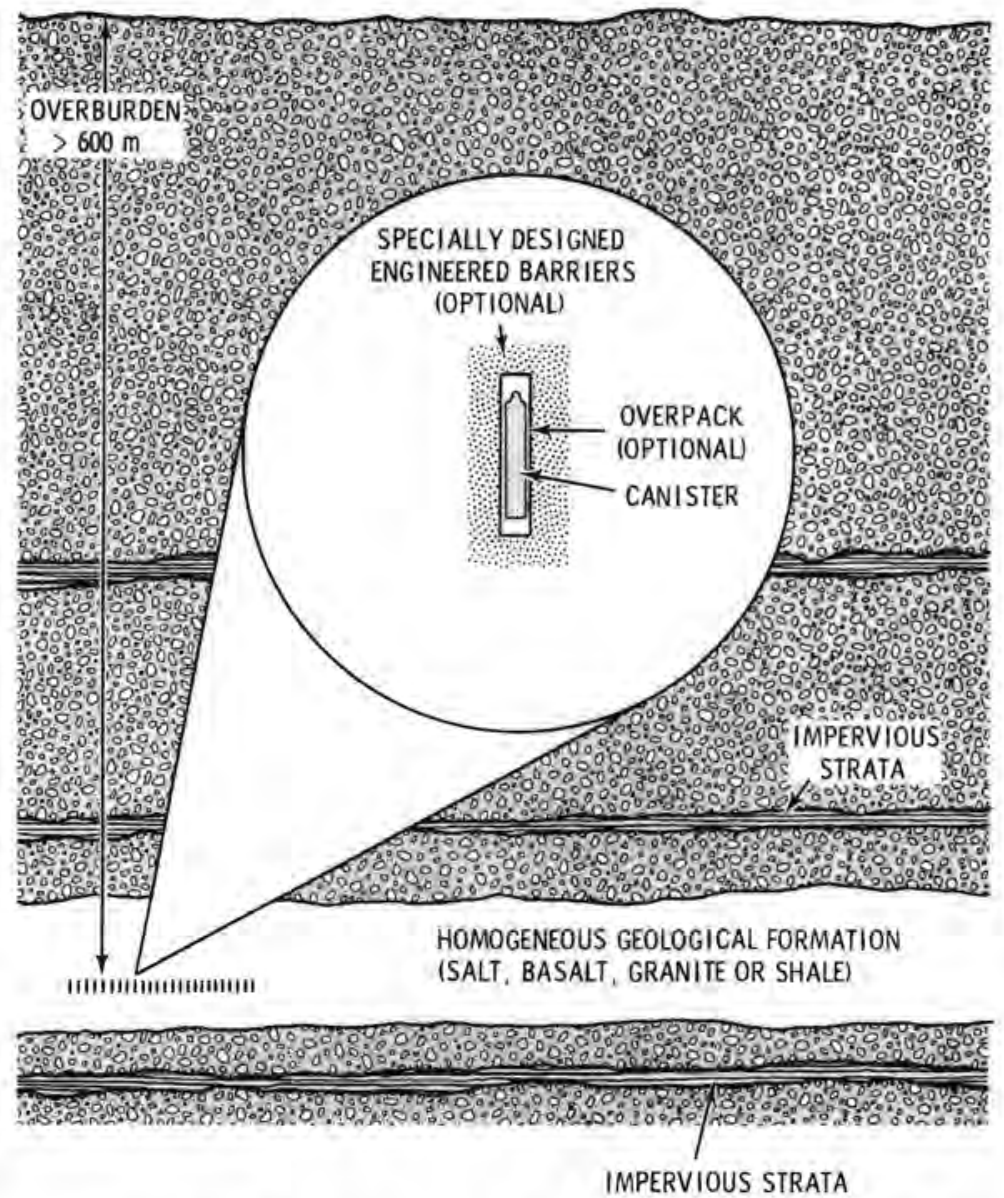

FIGURE III.1. Engineered Barrier Concept for Waste Isolation

- Canister - The sealed metal canister holding the solidified waste constitutes the primary barrier to dispersion of the radioactivity in the waste during handling, interim surface storage and transportation of the waste, but canister lifetime may be 1 imited after the waste is placed in a geologic repository.

- Solidified Waste Form - The function of the solidified waste form is to immobilize the high-level liquid waste in a stable, inert form that is compatible with the storage canister and with deep geologic disposal.

The barriers can be divided into two main types: absolute and rate-limiting. The first is exemplified by the canister, by many of the engineered barriers, and by some near-field geologic formations; the second is represented by the overburden, the solidified waste form, and some engineered barriers. In analyses of long-term behavior, the absolute barriers are step functions: at the end of a finite life their contribution becomes negligible. The rate1 imiting barriers then take over to further suppress the movement of the residual radioactivity. 


\section{WORKING-HYPOTHESIS WASTE FORM SPECIFICATIONS}

During this interim period, while waste form specifications are being defined, certain working hypotheses are being used. Among these are:

- Solidified HLW will be disposed of in deep geologic repositories; thus, the expected long-term behavior of the solidifed wastes in the repositories must be defined.

- Repository design may dictate certain waste form requirements; however, the waste form must still remain compatible with processing, interim storage and transportation.

- Geologic repositories will utilize an engineered barrier system.

Most solidified waste forms behave as rate-limiting barriers to the release of radioactivity. Thus, specifications applied to the waste forms ideally should define the degree of suppression that must be achieved in representative situations--especially in geologic repositories. The properties of the waste form should be predictable at any time in the repository. The major purposes of waste form characterization then become: 1) demonstration of waste form compatibility with absolute containment during its early history; 2) determination of what, if any, long-term effects temperature and radiation may have upon the waste form; and 3) determination of how the waste form will behave in situations (including accidents) in which it may be exposed to the surroundings. Judgments on the acceptability of candidate waste form behavior will come from analyses of the total multibarrier system. 


\section{WASTE FORM DEVELOPMENT: GLASS}

L. A. Chick, G. B. Mellinger

A number of properties are important when evaluating potential waste glass compositions. Among these are viscosity, electrical conductivity, and solids in the molten glass at process-

- ing temperatures. Others, which are important in the final product, are chemical durability and devitrification resistance. The behavior of each different glass is dependent upon its composition.

To date, most waste glass development has proceeded in an iterative manner: a proposed glass was tested, the developer decided which properties needed improvement, and adjustments to the composition were proposed to yield more acceptable properties. The new compositions were then tested and the process was repeated.

This year we have established a new approach to waste glass development at PNL. The objective is to develop an understanding of glass properties over broad compositional ranges so that, given a particular waste for vitrification, we will know better where to begin looking in the compositional field and will consequently find the optimal composition more efficiently.

Two studies exploring the new technique have been completed; a third is undei way. Here we report the highlights of these studies and discuss a more comprehensive study to be begun in the coming year.

\section{ONE-AT-A-TIME VARIATION STUDY ON DEFENSE WASTE GLASSES}

\section{Procedure}

In this study the effects that fifteen oxide glass components have upon glass properties were studied by establishing a base glass composition and changing the concentration of one component at a time while holding the other components at their base-glass proportions. The range of component variation is shown in Table IV.1. The base glass composition shown was a glass being considered for possible vitrification of a defense waste containing high levels of $\mathrm{Al}_{2} \mathrm{O}_{3}, \mathrm{Fe}_{2} \mathrm{O}_{3}$ and $\mathrm{MnO}_{2}$.

Viscosity and electrical conductivity were measured at $1070^{\circ} \mathrm{C}$. The crystallinity present in air-quenched samples was determined from photomicrographs. Chemical durability was tested in buffered pH-4 and pH-9 solutions at room temperature for 19 hours. A third sample was subjected to a Soxhlet $\left(99^{\circ} \mathrm{C}\right.$ distilled water for $\left.24 \mathrm{~h}\right)$. In each case, sample weight loss was measured.

\section{Results}

Table IV.1 summarizes the results. The alkali metals $(\mathrm{Li}, \mathrm{Na}, \mathrm{K})$ were found to have large effects upon nearly all properties measured. When property data were plotted as a function of mole-percent, no difference could be found among the effects of the three alkalis. The alkalis were the only components found to significantly affect electrical conductivity. The alkaline earth oxides ( $\mathrm{Mg}, \mathrm{Ca}, \mathrm{Ba}$ ) caused the same types of behavior as did the alkali oxides, except 
TABLE IV.1. Summary of Defense Waste Glass Study(a)

\begin{tabular}{|c|c|c|c|c|c|c|c|c|c|}
\hline $\begin{array}{c}\text { Oxide } \\
\text { Components } \\
\end{array}$ & $\begin{array}{c}\text { Base } \\
\text { Glass, } \\
\text { wt\% } \\
\end{array}$ & $\begin{array}{c}\text { Variation, } \\
\text { wt\% }\end{array}$ & Viscosity & $\begin{array}{c}\text { Electrical } \\
\text { Conductivity }\end{array}$ & $\begin{array}{c}\text { Crystal- } \\
\text { linity } \\
\end{array}$ & $\begin{array}{c}99^{\circ} \mathrm{C} \\
\text { Dist illed } \\
\text { Water } \\
\end{array}$ & $\mathrm{pH}-4^{(\mathrm{b})}$ & $\mathrm{pH}-9$ & $\begin{array}{l}\text { Devitri- } \\
\text { fication }\end{array}$ \\
\hline $\mathrm{Li}_{2} \mathrm{O}$ & 3.0 & $0-6.0$ & -- & + & -- & ++ & ++ & 0 & 0 \\
\hline $\mathrm{Na}_{2} \mathrm{O}$ & 13.9 & $5.0-15.0$ & -- & ++ & -- & ++ & ++ & 0 & 0 \\
\hline $\mathrm{K}_{2} \mathrm{O}$ & 0 & $0-6.0$ & -- & ++ & -- & + & ++ & 0 & 0 \\
\hline MgO & 0 & $0-3.0$ & 0 & 0 & 0 & + & H+ & 0 & 0 \\
\hline $\mathrm{CaO}$ & 4.53 & $0-6.0$ & -- & 0 & - & 0 & + & 0 & 0 \\
\hline $\mathrm{BaO}$ & 0 & $0-3.0$ & 0 & 0 & 0 & + & + & 0 & - \\
\hline $\mathrm{U}_{3} \mathrm{O}_{8}$ & 1.53 & $0-4.0$ & 0 & - & - & - & 0 & 0 & 0 \\
\hline $\mathrm{TiO}_{2}^{\circ}$ & 7.5 & $0-10.0$ & - & 0 & 0 & - & -- & 0 & + \\
\hline $\mathrm{MnO}_{2}$ & 2.58 & $1.16-4.0$ & 0 & 0 & + & - & + & 0 & 0 \\
\hline $\mathrm{Fe}_{2} \mathrm{O}_{3}$ & 7.9 & $0.39-15.41$ & - & 0 & + & 0 & + & 0 & + \\
\hline $\mathrm{NiO}$ & 0.53 & $0-3.0$ & + & 0 & + & 0 & 0 & 0 & 0 \\
\hline $\mathrm{ZnO}$ & 0 & $0-7.0$ & 0 & 0 & + & + & t+ & 0 & 0 \\
\hline $\mathrm{B}_{2} \mathrm{O}_{3}$ & 7.50 & $5.0-15.0$ & -- & - & - & 0 & + & 0 & - \\
\hline $\mathrm{Al}_{2} \mathrm{O}_{3}$ & 11.60 & $1.56-21.64$ & + & - & + & - & + & 0 & + \\
\hline $\mathrm{SiO}_{2}$ & 39.4 & --- & & & & & & 0 & \\
\hline
\end{tabular}

(a) 0 indicates negligible change with increase in this component, + and - indicate increases or decreases; ++ and -- indicate large increases and decreases with component increase.

(b) + indicates an increase in leachability.

that they didn't greatly affect electrical conductivity. On a per-mole basis, the influence of alkaline earth oxides on the other proprties was not as great and there was less uniformity in the effects they had upon on the glass.

Titanium dioxide was the only component found to cause a large increase in pH-4 durability. It is of interest that it also caused a slight decrease in viscosity, since oxides that increase durability generally increase viscosity as well.

Aluminum, nickel and iron were all found to increase the formation of nickel-ferrite spinel crystals in the glass. The action of the aluminum is not well understood, as it is not found in the crystals. It may act by occupying sites in the glass structure that would otherwise be held by iron atoms. This could cause the iron to precipitate out of the glass structure to form the crystals. Crystallite formation was found to be more sensitive to concentrations of nickel than to those of iron. Additional details of the experiments and the results were previously presented (Mellinger and Chick 1979).

\section{STATISTICAL DESIGN STUDY ON DEFENSE WASTE GLASSES}

Attaining an understanding of glass properties in the compositional field shown in Table IV.2 was the objective of this study, which employed computer-aided statistical experimental design. The composition of the defense waste calcine is shown in Table IV.3. A computer program was used to choose 25 widely spaced test compositions lying on the boundaries of the composition field. The centroid and eight other compositions within the interior of the 
TABLE IV.2. Composition Field for Defense Waste Study

\begin{tabular}{|c|c|c|c|}
\hline Component & $\begin{array}{c}\text { Low Value, } \\
\text { mole\% }\end{array}$ & $\begin{array}{c}\text { High Value, } \\
\text { mole\% }\end{array}$ & $\begin{array}{l}\text { Centroid } \\
\text { Value, } \\
\text { mole\% }\end{array}$ \\
\hline $\mathrm{CaO}$ & 0 & 8 & 3.99 \\
\hline $\mathrm{B}_{2} \mathrm{O}_{3}$ & 0 & 13 & 6.41 \\
\hline $\mathrm{SiO}_{2}$ & 36 & 51 & 43.50 \\
\hline $\mathrm{Na}_{2} \mathrm{O}$ & 15 & 35 & 25.60 \\
\hline Calcine & 10 & 30 & 20.50 \\
\hline
\end{tabular}

TABLE IV.3. Defense Waste Calcine Composition

\begin{tabular}{lrrrr}
\cline { 1 - 1 } Component & & Wt\% & & Mole\% \\
\cline { 1 - 1 } $\mathrm{SiO}_{2}$ & & 3.85 & & 8.04 \\
$\mathrm{Na}_{2} \mathrm{CO}_{3}$ & & 1.16 & & 1.37 \\
$\mathrm{CaCO}_{3}$ & & 7.51 & 9.41 \\
$\mathrm{Fe}_{2} \mathrm{O}_{3}$ & & 48.94 & 38.40 \\
$\mathrm{Al}_{2} \mathrm{O}_{3}$ & & 10.02 & & 12.31 \\
$\mathrm{MnO}_{2}$ & & 13.01 & & 18.74 \\
$\mathrm{NiO}_{2}$ & & 6.17 & 10.34 \\
Zeolite & & 8.09 & & 0.29 \\
$\mathrm{Na}_{2} \mathrm{SO}_{4}$ & & 1.25 & & 1.10
\end{tabular}

field were also selected for testing. Among the properties determined were: 1) weight loss after $24 \mathrm{~h}$ in $99^{\circ} \mathrm{C}$ distilled water (Soxhlet) (Mendel et al. 1977); 2) weight loss after $19 \mathrm{~h}$ in buffered $\mathrm{pH}-4$ solution at room temperature ( $\mathrm{pH}-4)$ (Mendel et al. 1977); 3) temperature at which the viscosity was 100 poise; and 4) weight-percent of nickel-manganese-ferrite spinel crystals formed after a heat treatment of $1 \mathrm{~h}$ at $1150^{\circ} \mathrm{C}, 2 \mathrm{~h}$ at $1050^{\circ} \mathrm{C}$, and $2 \mathrm{~h}$ at $900^{\circ} \mathrm{C}$, followed by cooling with the furnace power shut off.

The data were fit to a partial cubic approximation model by least-squares analysis as a function of composition. These fitted models were used to predict the properties of glasses plotted in Figures IV.1 through IV.4. These figures show the predicted effects increasing or decreasing the level of a component from its level in the centroid composition (Table IV.2) has upon properties. The property value plotted at the $0 \%$ change point (where the curves intersect) is the predicted value for the centroid composition. As a component level is changed, the other component levels are adjusted but remain in the same proportions as in the centroid compositions. The magnitudes of the prediction-error standard deviations (error bars) shown demonstrate that curves which lie close together cannot be considered to be significantly different.

These "effects plots" illustrate the compromises necessary to balance acceptable final $\mathrm{glass}$ properties with processing practicality. For instance, reduction of $\mathrm{Na}_{2} \mathrm{O}$ by $10 \mathrm{~mole} \%$ would yield large improvements in chemical durability but would increase the melting temperature by almost $300^{\circ} \mathrm{C}$. 


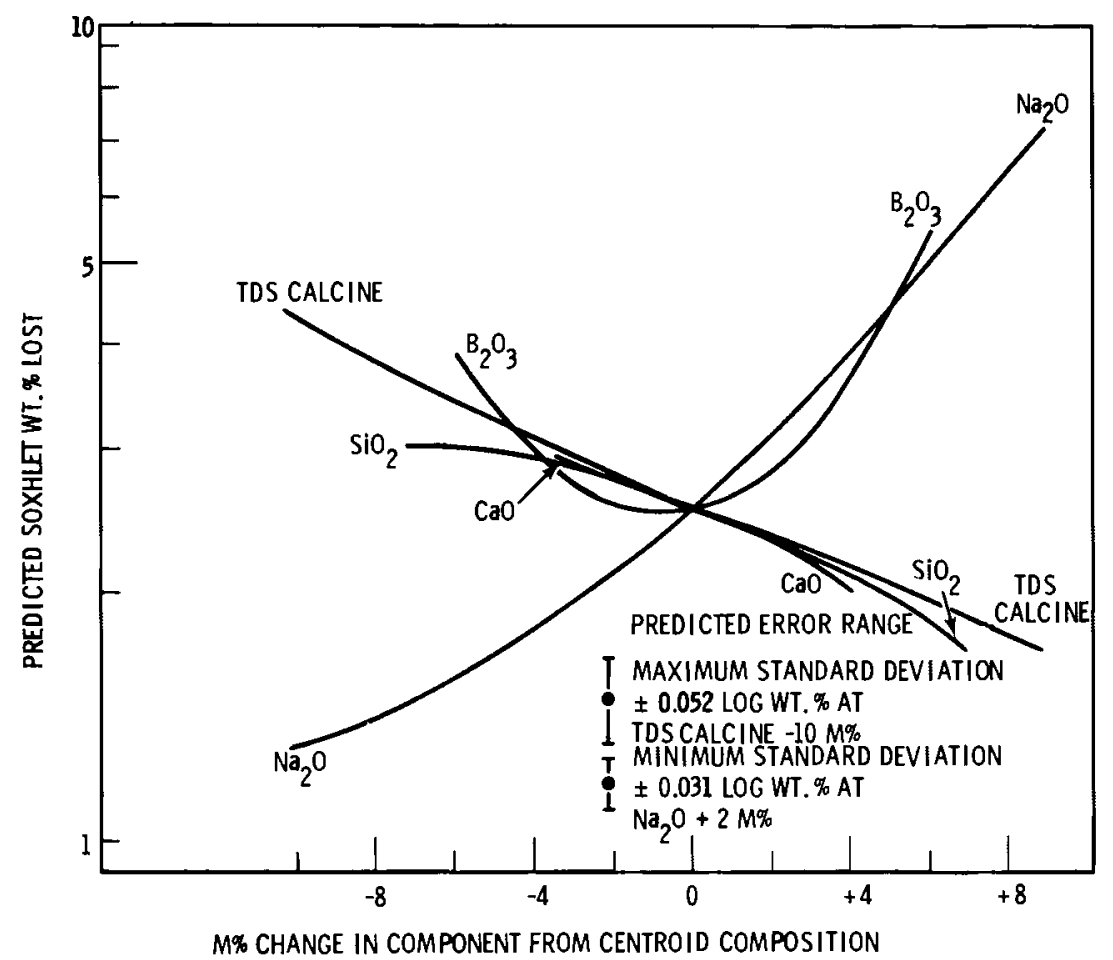

FIGURE IV.1. Effects of Components on Soxhlet Leach Rate

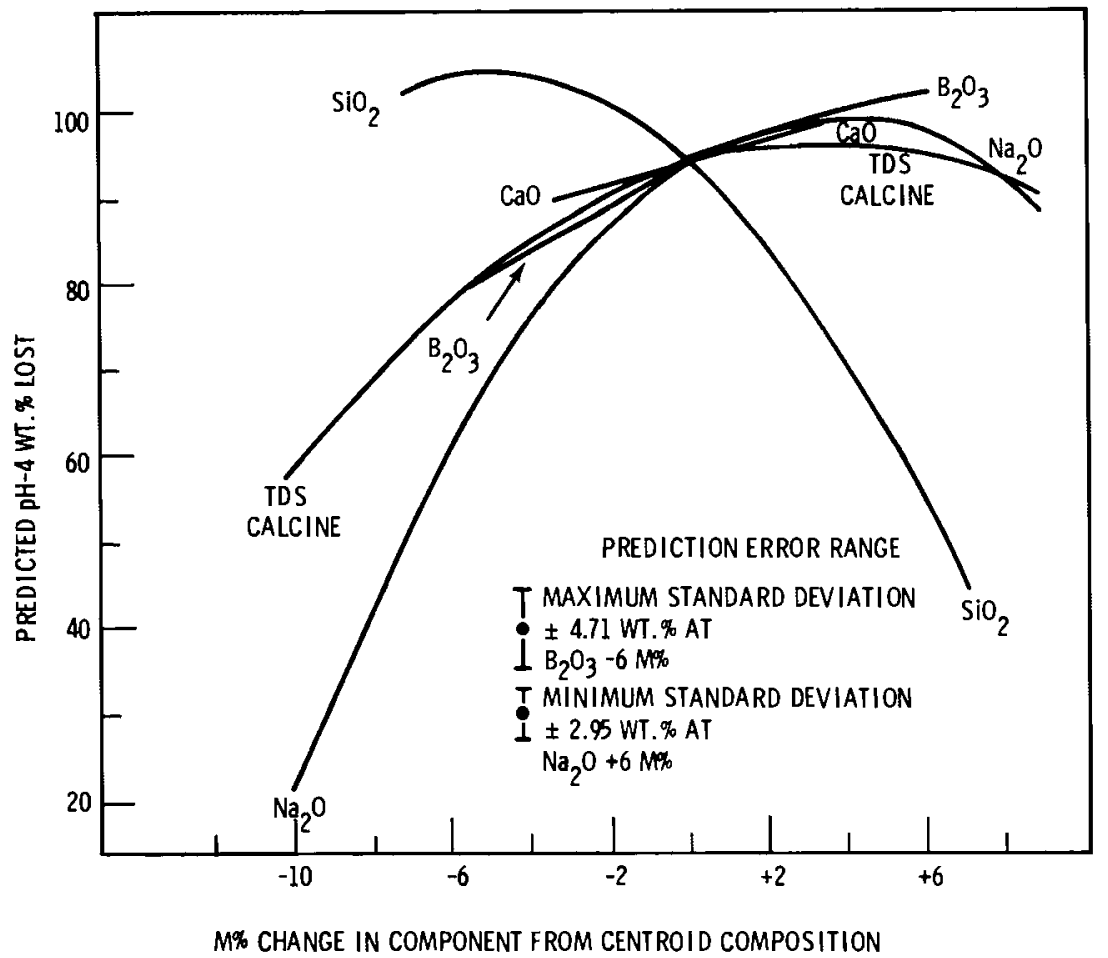

FIGURE IV.2. Effects of Components on pH-4 Leach Rate 


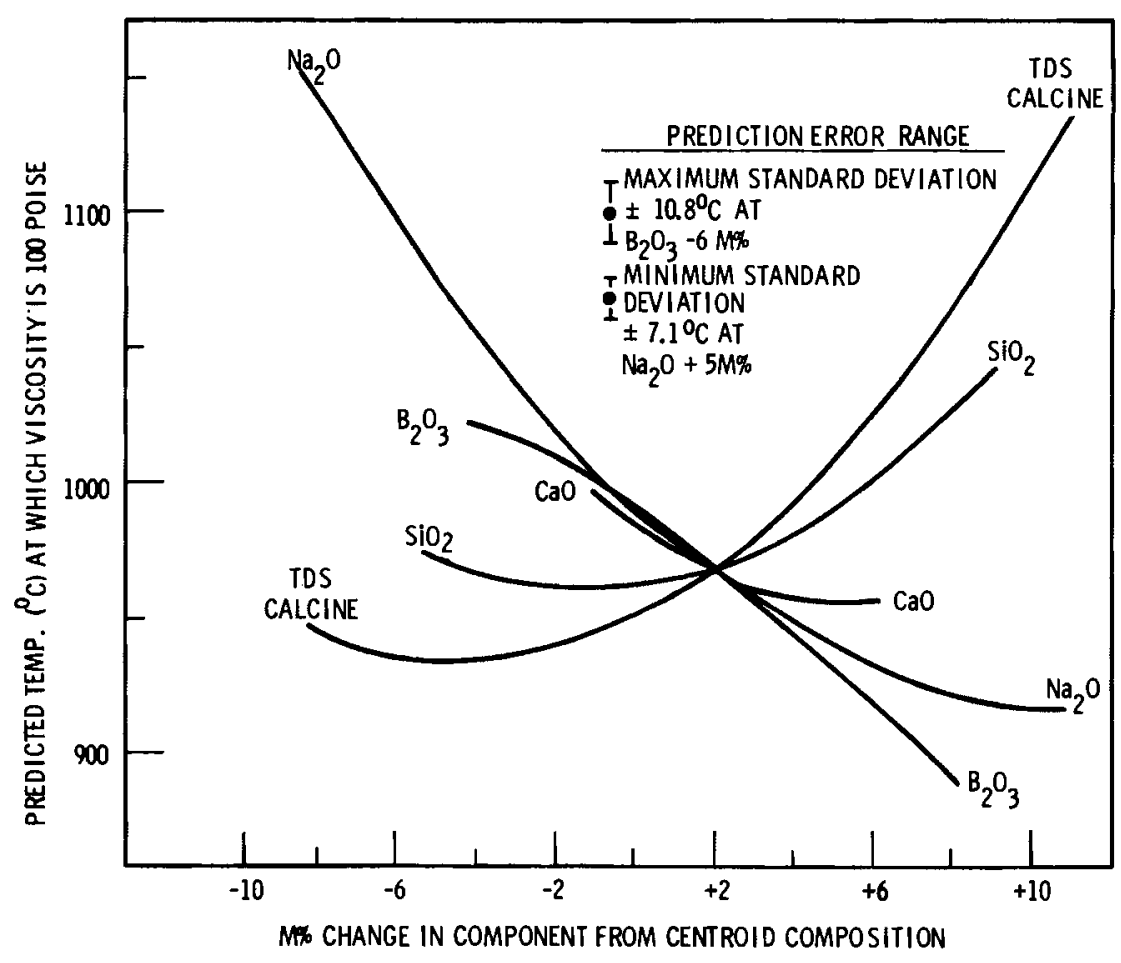

FIGURE IV.3. Effects of Components on Temperature at Which Viscosity $=100$ Poise

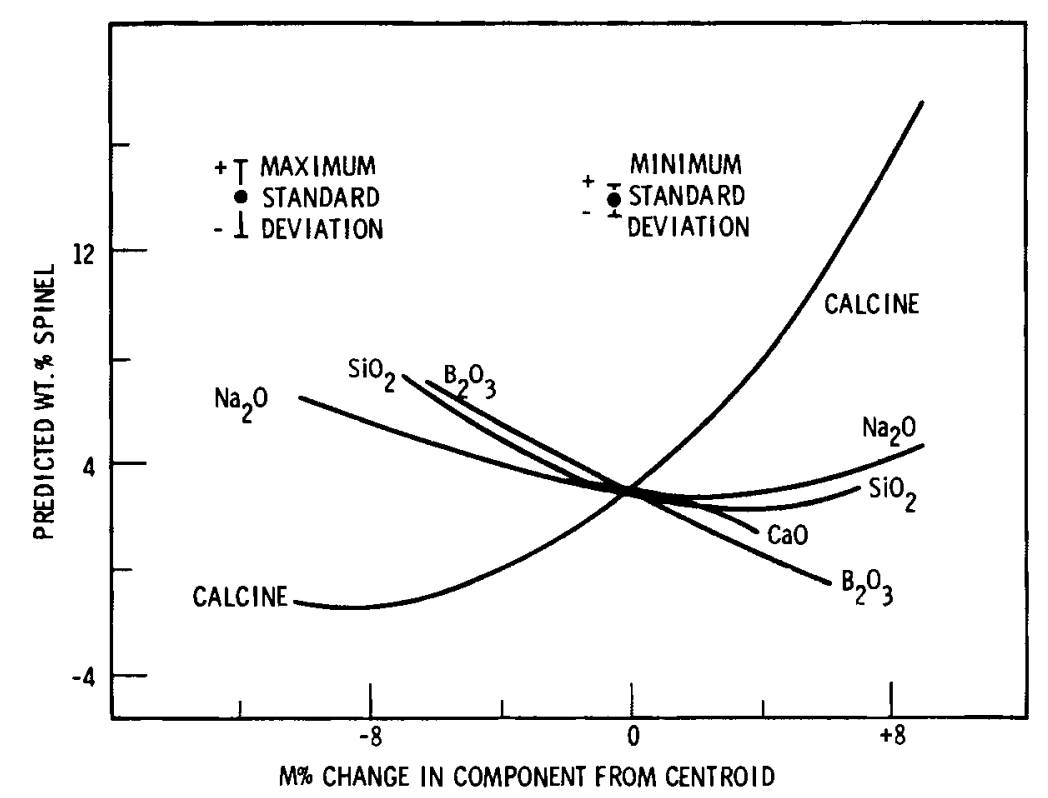

FIGURE IV.4. Effects of Components on Weight-Percent Spinel 
A review of spinel formation further illustrates the flexibility of interpretation that results from the development and use of approximation modeling for glass properties as a function of glass composition. None of the components in the full experimental design except for the waste calcine were found to have 1 arge effects upon the percentage of spinel crystals formed. Later, however, several additional glasses containing various levels of $\mathrm{Li}_{2} \mathrm{O}$ were tested. A model was fitted that included $\mathrm{Li}_{2} \mathrm{O}$ as a component, and $\mathrm{Li}_{2} \mathrm{O}$ was discovered to have the effect of increasing the amount of spinel. Figure IV.5 is the effects plot that includes

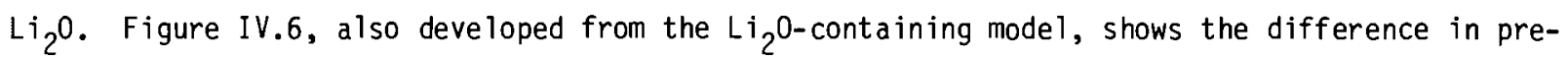
dicted percent spinel versus calcine loading for a frit containing no $\mathrm{Li}_{2} \mathrm{O}$ and for another with half of its $\mathrm{Na}_{2} \mathrm{O}$ replaced by $\mathrm{Li}_{2} \mathrm{O}$. At the usual intended production calcine level of about 15 mole\%, little or no spinel should form in either glass. However, if localized regions of glass containing higher amounts of calcine are formed in the melter as a result of inadequate frit and calcine mixing, significant amounts of spinel will form where the temperature is below the liquidus level. The lithium-containing frit will produce more spinel than will the frit without lithium.

Figure IV.7 is a graph of predicted viscosity at $1000^{\circ} \mathrm{C}$ versus calcine loading for the same two frits. As expected, at low calcine loadings the lithium-containing frit produces lower viscosities than does the frit without lithium. However, presumably as a result of increased spinel production, the lithium frit curve crosses and rises higher than does the curve without lithium at the higher calcine loadings. Comparison of Figures IV.6 and IV.7

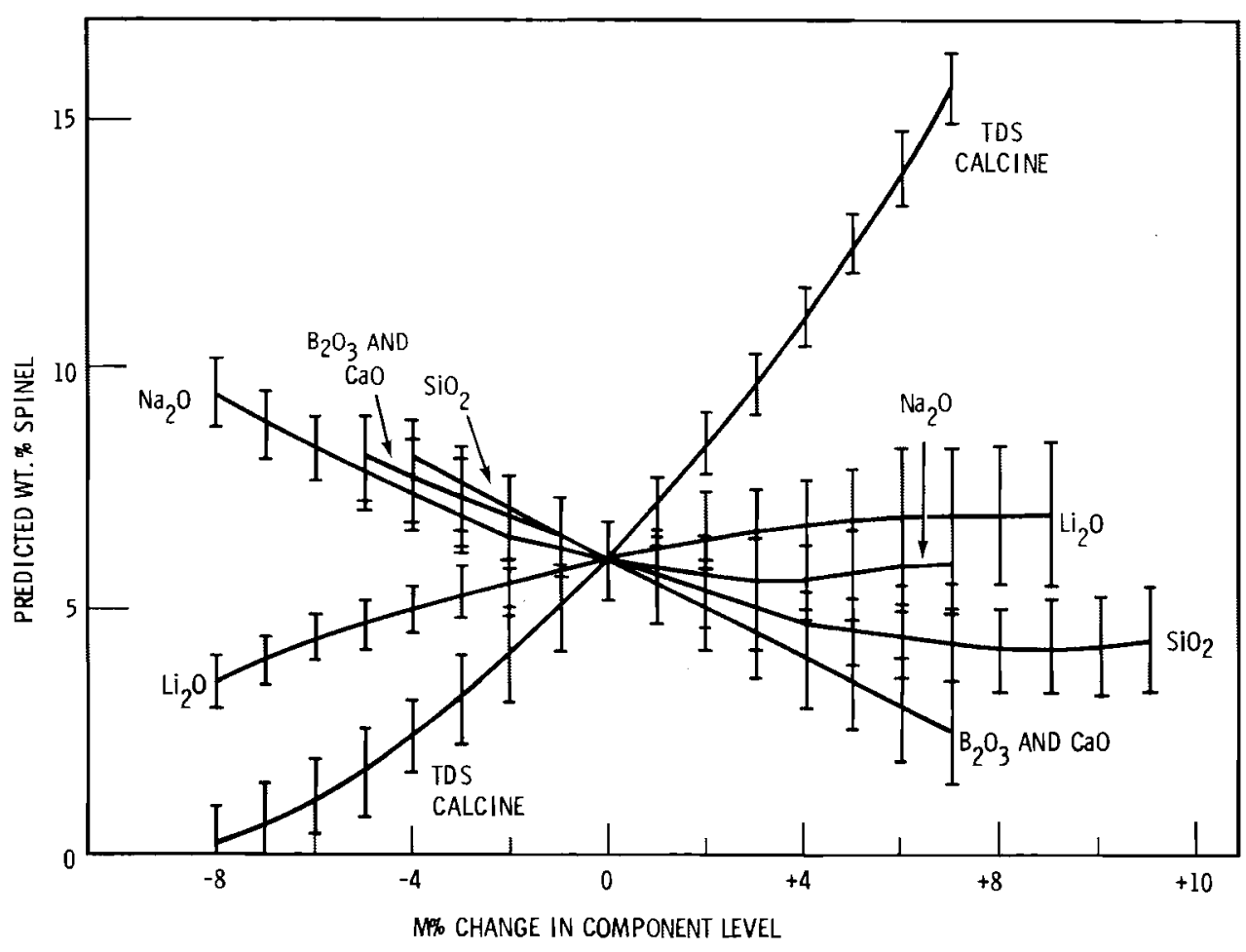

FIGURE IV.5. Effect of SRP/TDS Study Components on Predicted We ight-Percent Spinel 
shows that lithium-containing glasses with 30 mole\% calcine could produce nearly 30 wt\% spinel and have viscosities of roughly 1500 poise at $1000^{\circ} \mathrm{C}$.

After localized agglomerations of spinel form in the melter, they can be expected to persist because of their high viscosities and resulting resistance to dissolution. They can also be expected to sink to the melter bottom because of their high densities.

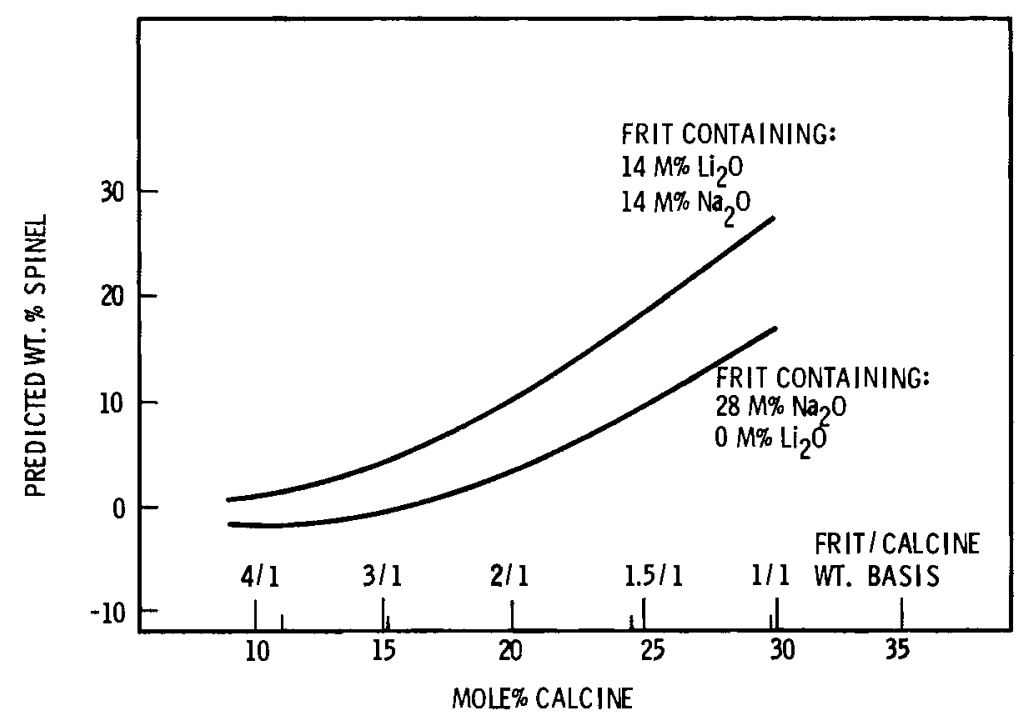

FIGURE IV.6. Weight-Percent Spinel Versus Calcine Loading

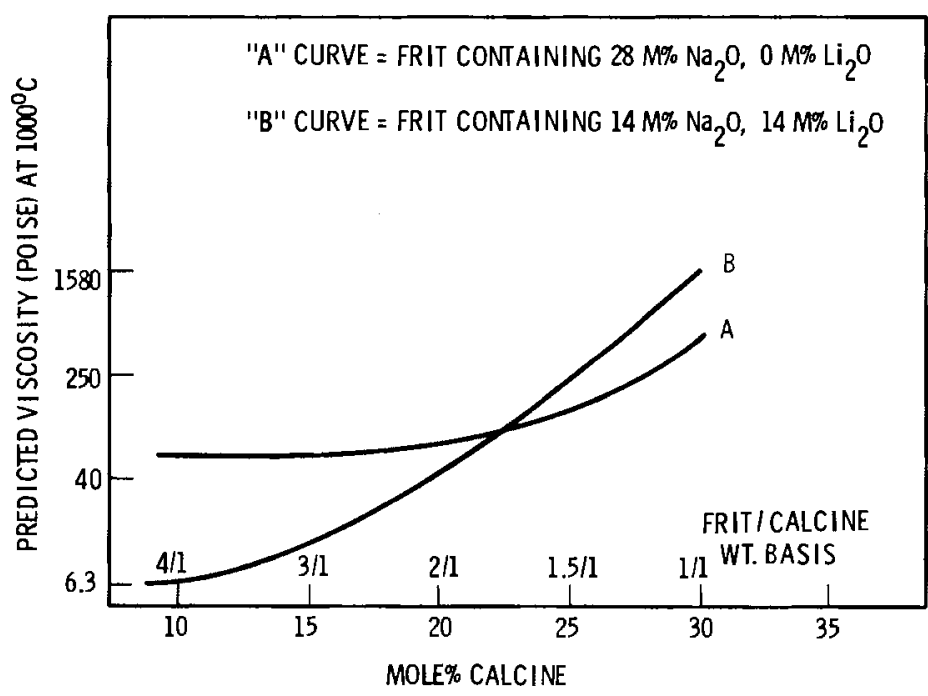

FIGURE IV.7. Log Viscosity Versus Calcine Loading 


\section{ELEVEN-COMPONENT MIXTURE DESIGN STUDY ON GENERIC WASTE GLASSES}

A study of the eleven-component waste glass system shown in Table IV. 4 was begun using the experimental design and modeling methods described in the previous section. The increased number of components would result in the choice of unreasonable-extreme test compositions with properties beyond measurement ranges if the restrictions shown at the bottom of the table were not $\mathrm{placed}$ upon the allowable limits of the sums of glass network formers, modifiers, and intermediates.

Adequate modeling of this system will necessitate testing of approximately 70 compositions. Twenty-one have been tested so $f a r$ and preliminary models of partial quadratic form have been developed. Figures IV.8 through IV.11 are the resulting effects plots. The magnitude of the prediction-error bars at this early stage precludes detailed interpretation. One surprising result is the apparent pronounced effect of chromium on Soxhlet leach rate, viscosity, and volatility.

Properties besides those shown in Figures IV. 8 through IV.11 that will be studied on all or part of the melts will include devitrification and phase separation behavior, mechanical strength, thermal expansion, $\mathrm{pH}-4$ leach rate, leach rate of specific elements, and radiation damage behavior.

TABLE IV.4. Composition Field for Eleven-Component Generic Study (a)

\begin{tabular}{|c|c|c|c|}
\hline Component & $\begin{array}{l}\text { Low } \\
\text { Value, } \\
\text { mole\% } \\
\end{array}$ & $\begin{array}{c}\text { High } \\
\text { Value, } \\
\text { mole\% } \\
\end{array}$ & $\begin{array}{l}\text { Centroid } \\
\text { Value, } \\
\text { mole\% }\end{array}$ \\
\hline \multicolumn{4}{|l|}{ Formers } \\
\hline $\mathrm{SiO}_{2}$ & 42 & 58 & 49.03 \\
\hline $\mathrm{B}_{2} \mathrm{O}_{3}$ & 6 & 12 & 8.82 \\
\hline $\mathrm{Al}_{2} \mathrm{O}_{3}$ & 0 & 15 & 7.35 \\
\hline \multicolumn{4}{|l|}{ Modifiers } \\
\hline $\mathrm{Na}_{2} \mathrm{O}$ & 11 & 16 & 13.24 \\
\hline $\mathrm{Ca} 0$ & 0 & 14 & 6.86 \\
\hline $\mathrm{MgO}$ & 0 & 8 & 3.92 \\
\hline \multicolumn{4}{|c|}{ Intermediates } \\
\hline Zno & 0 & 6 & 2.94 \\
\hline $\mathrm{TiO}_{2}$ & 0 & 7 & 3.43 \\
\hline $\mathrm{Cr}_{2} \mathrm{O}_{3}$ & 0 & 3 & 1.47 \\
\hline $\mathrm{Fe}_{2} \mathrm{O}_{3}$ & 0 & 3 & 1.47 \\
\hline $\mathrm{NiO}$ & 0 & 3 & 1.47 \\
\hline
\end{tabular}




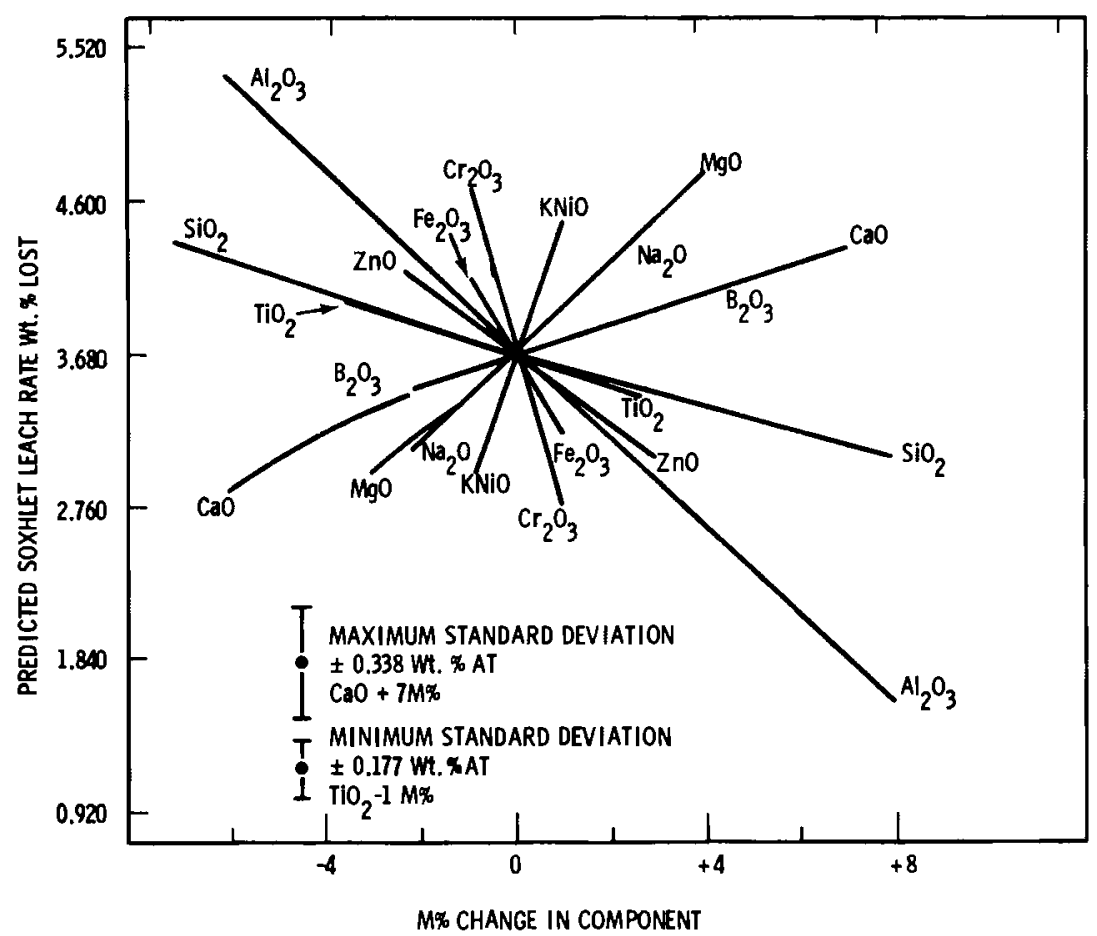

FIGURE IV.8. Soxhlet Leach Rate Versus Change in Component from Centroid

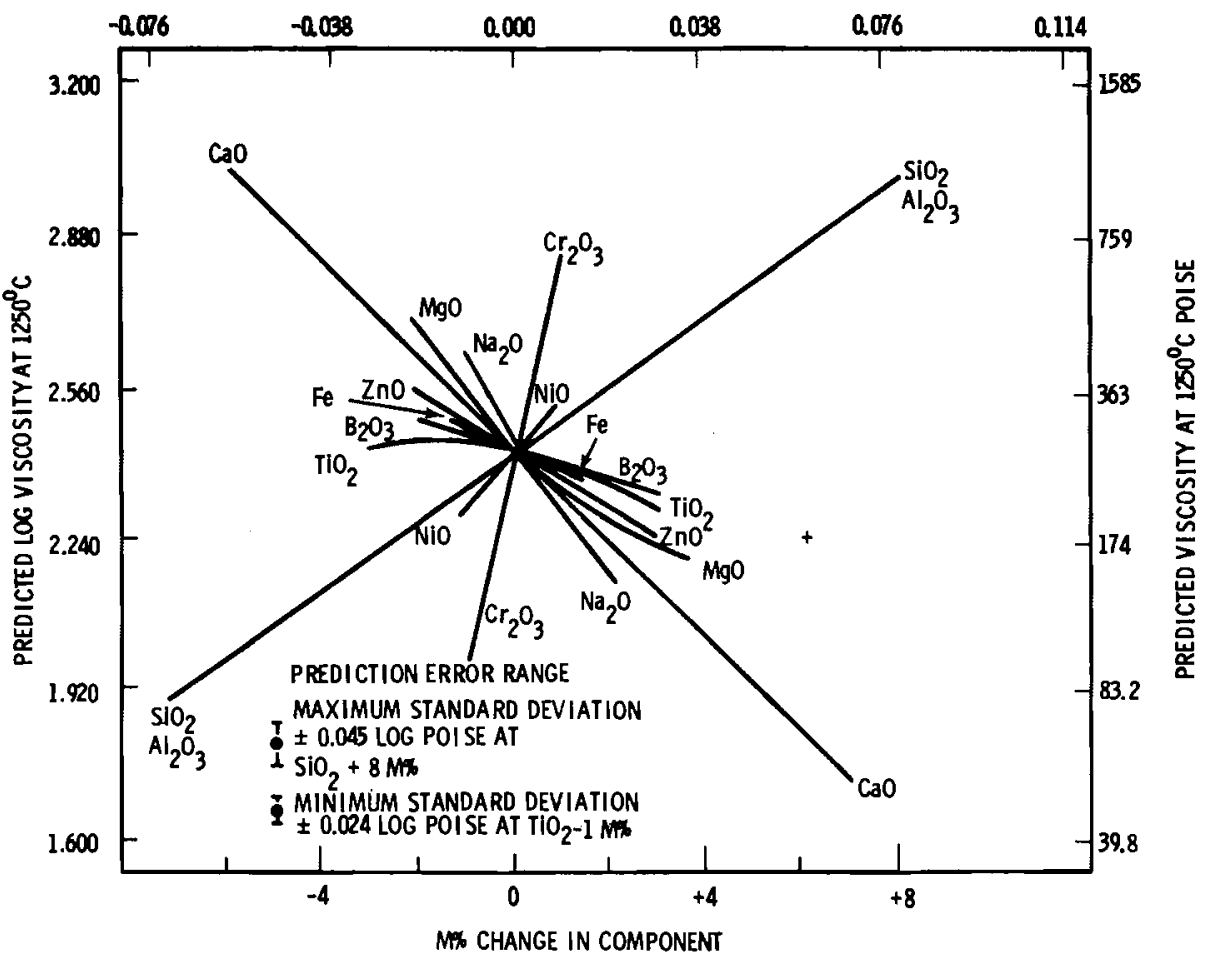

FIGURE IV.9. Log Viscosity Versus Change in Component from Centroid 


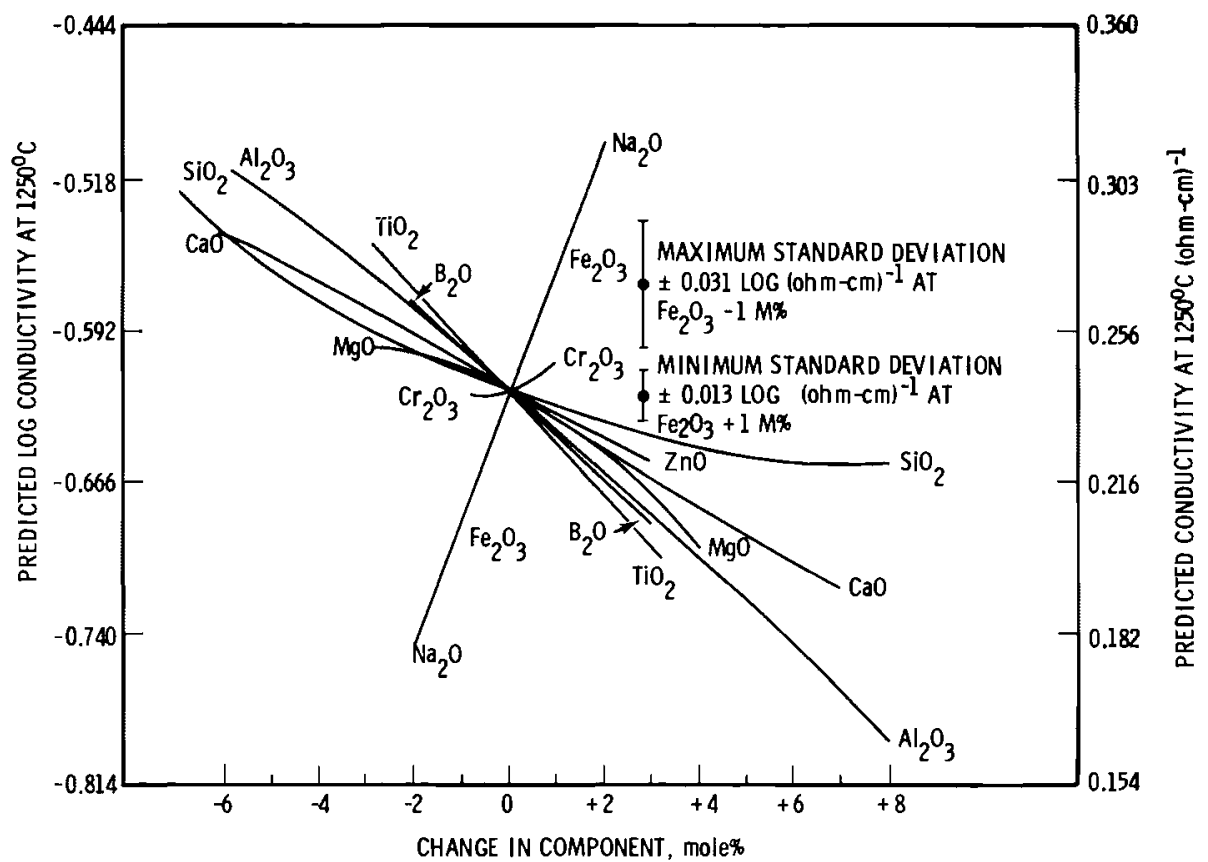

FIGURE IV.10. Log Conductivity Versus Change in Component from Centroid

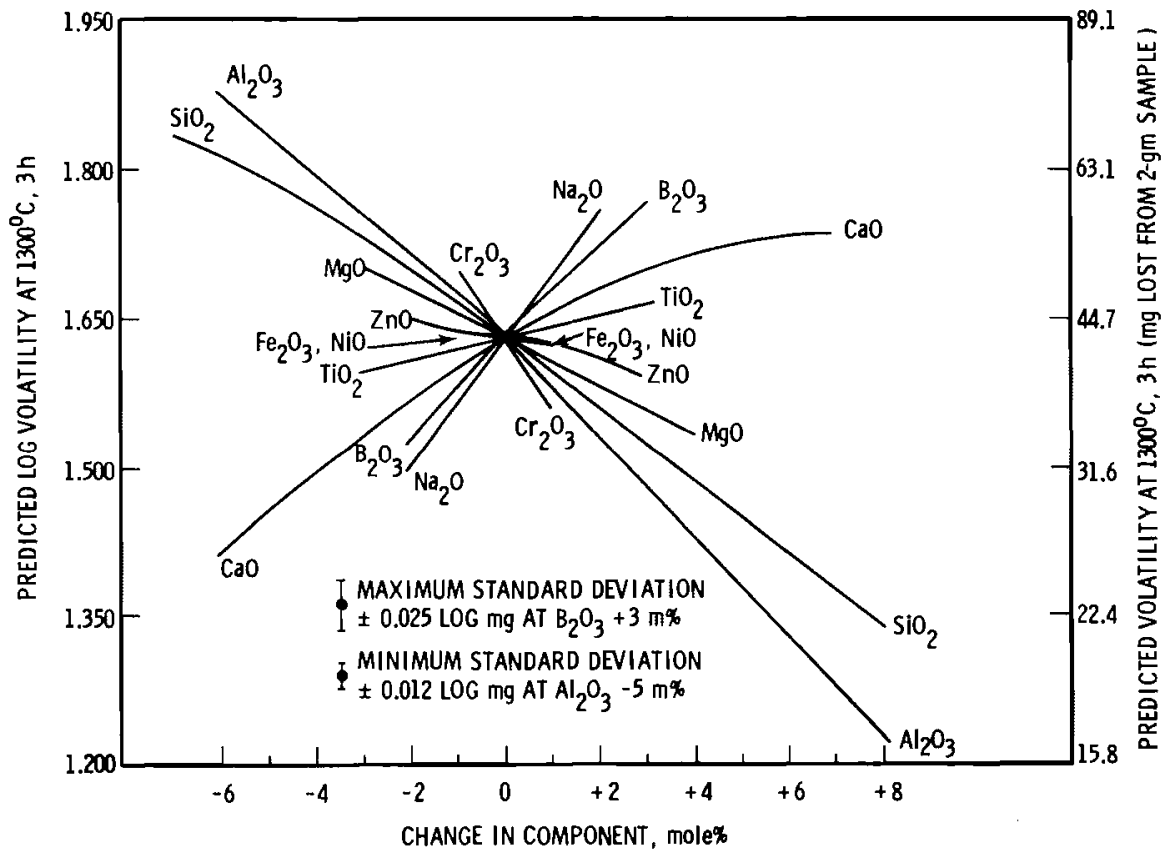

FIGURE IV.Il. Log Volatility Versus Change in Component from Centroid 


\section{FULL GENERIC STUDY}

If the eleven-component study is successful, we plan to attempt a much larger compositional field designed to encompass all nuclear waste glasses. This full study would involve roughly 25 components and several hundred test melts. 
, 


\section{ALTERNATIVE WASTE FORM DEVELOPMENT}

J. M. Rusin, R. 0. Lokken

Development of alternatives to the cast-glass waste form was initiated at PNL in 1973.

The original objectives of this program were:

- to provide a backup or second-generation process;

- to produce a waste form that has improved durability and lower dispersibility;

- to produce inert forms from wastes not readily compatible with vitrification;

- to increase reliability through process simplification;

- to reduce the cost of solidification and/or storage.

It became apparent that the objectives of simplification and cost reduction could not realistically be achieved along with those of increased inertness. Thus, the primary goal of the program became to provide a backup or second-generation waste form of improved inertness.

The major effort from 1973 to 1978 was to develop alternative waste forms based upon a multibarrier concept, as shown in Figure V.1; these waste forms should not be confused with the engineered barriers discussed in Section III. This aspect of the multibarrier concept is designed to separate the radionuclide-containing inner core material from the environment by the use of coatings and metal matrices. The resultant composite waste form exhibits increased inertness due to improved thermal stability and mechanical strength, and the added barriers greatly improve leach resistance. Present development of the multibarrier concept was concluded this year by the production and characterization of four one-liter canisters that demonstrate various multibarrier concepts. The program will now be directed toward the characterization of other alternative waste form products. This will be achieved by a comparative study in which waste forms are characterized by standard tests and are compared to glass as the reference waste form. Reviews of waste processing methods and product characteristics have been published by Ross, Rusin and McElroy (1979); Rusin, Lokken and Wald (1979a); and Ross et al. (1979).

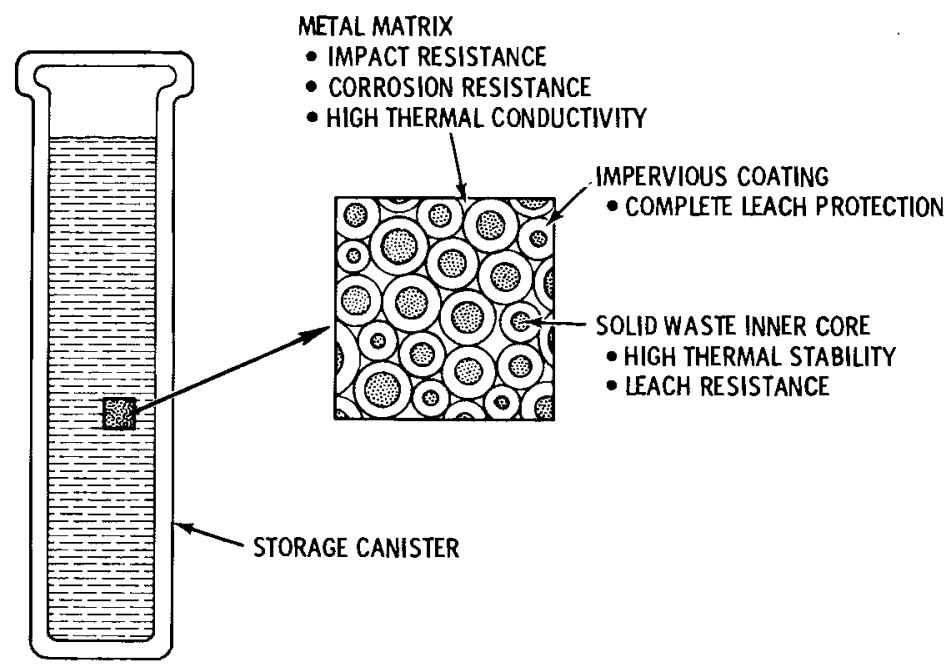

FIGURE V.1. Multibarrier Concept for Isolating High-Level Waste 


\section{MULTIBARRIER WASTE FORMS}

Multibarrier waste forms have three major components: 1) the inner core particles that contain the radioactive waste; 2) an inert nonradioactive coating that is applied to each particle; and 3) a metal matrix around the cores that provides improved thermal conductivity, impact resistance, and in some cases, additional leach resistance.

\section{Inner Core Development}

Two options were developed for the inner core of the multibarrier concept: sinteredceramic pellets and glass marbles.

\section{Sintered-Ceramic Inner Cores}

Sintered-ceramics are crystalline assemblages of mutually compatible, refractory, and leach-resistant solid-solution phases incorporating HLW ions. Supercalcine is one sinteredceramic under investigation at Pennsylvania State University and PNL. Supercalcine powder is produced by spray-calcining liquid waste to which $\mathrm{Al}_{2} \mathrm{O}_{3}, \mathrm{CaO}, \mathrm{SiO}_{2}$, and $\mathrm{Sr}_{0}$ have been added.

Two synthetic mineral models (SPC-2 and SPC-4) have been developed for use as a core material of the multibarrier product (Rusin et al. 1978). The crystal chemical roles of waste ions are given in Table V.1. The formulae in this table are only nominal. Each of the nominal compositions has been synthesized separately and its $x$-ray diffraction pattern matched to the corresponding reflections in the diffractogram of the crystallized sintered-ceramic.

The major phases given in Table V.1 have been determined from more than 200 crystal chemical and compatibility studies (McCarthy 1977), but minor formation and the partitioning of

TABLE V.1. Crystal Chemical Roles of Waste Ions(a)

\begin{tabular}{|c|c|c|}
\hline Ions & $\begin{array}{l}\text { Nominal Composition } \\
\text { Of Synthetic Mineral }\end{array}$ & Structure Type \\
\hline $\begin{array}{l}\mathrm{Sr}, \operatorname{Ln}(\mathrm{b}) \\
\mathrm{Ln},\left[\mathrm{PO}_{4}\right]\end{array}$ & $\left(\frac{\mathrm{Ca}}{\mathrm{nP}}, \frac{\mathrm{Sr}}{4}\right)_{2} \mathrm{Ln}_{8}\left(\mathrm{SiO}_{4}\right)_{6} \mathrm{O}_{2}^{(\mathrm{c})}$ & $\begin{array}{l}\text { Apatite }\left[\mathrm{A}_{S \mathrm{~S}}\right] \\
\text { Monazite }\left[\mathrm{M}_{S \mathrm{~S}}\right]\end{array}$ \\
\hline $\mathrm{Cs}, \mathrm{Rb}, \mathrm{Na}$ & $(\mathrm{Cs}, \mathrm{Rb}, \mathrm{Na}){ }_{\mathrm{AlSi}}{ }_{2} \mathrm{O}_{6}$ & Pollucite $[P]$ \\
\hline $\mathrm{Sr}, \mathrm{Ba}$ & $(\underline{\mathrm{Ca}}, \underline{\mathrm{Sr}}, \mathrm{Ba}) \mathrm{MoO}_{4}$ & Scheelite $\left[\mathrm{S}_{s \mathrm{~s}}\right]$ \\
\hline U,Ce,Zr & $(U, C e, Z r \ldots) 0_{2+x}$ & Fluorite $\left[F_{s s}\right]$ \\
\hline $\mathrm{Zr}, \mathrm{Ce}, \mathrm{U}$ & $(\mathrm{Zr}, \mathrm{Ce}, \mathrm{U} \ldots) 0_{2+\mathrm{x}}$ & $\begin{array}{l}\text { Tetragonal- } \\
\quad \text { Fluorite }\left[\mathrm{T}_{\mathrm{SS}}\right]\end{array}$ \\
\hline \multirow[t]{2}{*}{$\mathrm{Fe}, \mathrm{Ni}, \mathrm{Cr}$} & $\begin{array}{l}(\mathrm{Ni}, \mathrm{Fe})(\mathrm{Fe}, \mathrm{Cr})_{2} \mathrm{O}_{4} \\
\text { and }\end{array}$ & Spinel $\left[\mathrm{Sp}_{\mathrm{ss}}\right]$ \\
\hline & $(\mathrm{Fe}, \mathrm{Cr})_{2} \mathrm{O}_{3}$ & $\begin{array}{l}\text { Corundum } \\
{\left[\mathrm{Fe}_{2} \mathrm{O}_{3}\right]_{\mathrm{sS}}}\end{array}$ \\
\hline Ru & $\mathrm{RuO}_{2}$ & Rutile \\
\hline
\end{tabular}

(a) Te,Pd, Rh, Tc, Pm, Np, Pu, Am, and $\mathrm{Cm}$ were not included in the simulated waste.

(b) $\mathrm{Ln}=\mathrm{La}, \mathrm{Pr}, \mathrm{Nd}, \mathrm{Sm}, \mathrm{Eu}, \mathrm{Gd}, \mathrm{Y}$.

(c) Additive ions are underlined. Strontium is also a waste ion. 
ions among two or more phases is to be expected. For example, the rare earth ions are partitioned between the apatite and monazite phases, and a small amount may also be substituting in the fluorite and tetragonal-zirconia phases. The submicrometer dimensions of most of the crystals disqualify routine electron microprobe elemental characterization, but scanning transmission electron microscopy (STEM) will be utilized for direct characterization of elemental distributions in sintered-ceramic crystals in the near future.

From Table V.1 it can be seen that only four additives may be needed to tailor the liquid waste compositions: $\mathrm{Ca}, \mathrm{Al}, \mathrm{Sr}$ and $\mathrm{Si}$. Nitrates of $\mathrm{Ca}, \mathrm{Sr}$ and $\mathrm{Al}$ and colloidal silica are the liquid sources of these elements. Typically, twice the stoichiometrically required level of additives are specified, because the day-to-day waste stream compositions are expected to vary considerably. The extra $\mathrm{Ca}$ would fix transient excesses of Mo, and the combination of $\mathrm{Al}$ and $\mathrm{Si}$ serves the same purpose for the alkali elements. If the excess additives are not completely combined with waste constituents, they form an inert but generally x-ray-amorphous calcium-aluminosilicate phase.

Process simplicity, advanced stages of process development, demonstrated operating capability, and highly desirable calcine powder characteristics make the spray calciner ideally suited to the production of a reactive amorphous powder. The amorphous spray-calcined powder consists of metal oxides, a trace of moisture and some residual nitrates or carbonates, depending upon feedstock composition. The powder is very fine and typically displays surface areas of 10 to $20 \mathrm{~m}^{2} / \mathrm{g}$.

Consolidated pellets are produced from the amorphous spray calcine powder by disc-pelletizing. Disc-pelletizing is an agglomeration technique that forms spherical pellets from powders (Floyd and Engelleitner 1967). The purpose of pelletizing the spray-calcined powder was to produce consolidated, high-density spheres (pellets) about 1 to $7 \mathrm{~mm}$ in dia that can be sintered and crystallized by subsequent heat treatment.

The sintering behavior of supercalcine was studied to identify parameters to be used in the densification and crystallization of sintered-ceramic pellets and to identify differences in sintering behavior among various preparation techniques and/or formulations. Two methods were used--one incorporating a bulk-vibrated sample with a density typical of disc-pelletizing, and the other a pressed sample representative of standard sintering tests.

For the bulk test, alumina crucibles were filled and vibrated to produce powder samples with densities comparable to that of pelletized supercalcine $\left(0.90\right.$ to $\left.1.15 \mathrm{~g} / \mathrm{cm}^{3}\right)$. The second series of sintered samples was produced by pressing as-prepared calcine powder at 3400 psi in a 0.75-in. steel punch and die. Table V.2 summarizes the sintering information for pressed, vibrated, and disc-pelletized calcine.

The resulting pelletized sintered densities were within experimental error of the values obtained for the vibrated sintered samples. Thus, the vibrated samples were used to determine proper process conditions.

Glass Marble Inner Cores

Glass marbles provide an alternative to the cast glass waste form but do not require the development of a new waste form material. Marble production would provide a separate step 
TABLE V.2. Sintered Density of Sintered-Ceramics

\begin{tabular}{|c|c|c|}
\hline Material and Treatment & $\begin{array}{l}\text { Sintering } \\
\text { Temp., }{ }^{2}\end{array}$ & $\begin{array}{l}\text { Bulk Sintering } \\
\text { Density, } \mathrm{g} / \mathrm{cm}\end{array}$ \\
\hline SPC-2, pressed & 1100 & 3.22 \\
\hline$S P C-4$, pressed & 1200 & 4.21 \\
\hline SPC-2, vibrated & 1170 & 3.84 \\
\hline SPC-4, vibrated & 1230 & 3.68 \\
\hline SPC-2, pelletized & 1175 & 3.84 \\
\hline SPC-4, pelletized & 1230 & 3.60 \\
\hline
\end{tabular}

between the melter and the canister to allow for quality assurance and ease of recycling to the melter if a below-standard product is produced.

The technique used to produce simulated waste glass marbles for multibarrier development is a laboratory-scale version of a process developed by Knapp and Smith (1962). The process incorporates the direct casting of a glass stream into vibrating molds. The cavities in the molds are conical and have hemispherical bottoms.

\section{Coating Development}

The development of coatings for sintered-ceramics was pursued to provide an additional protective layer between the radionuclides and the environment. The chemical vapor deposition

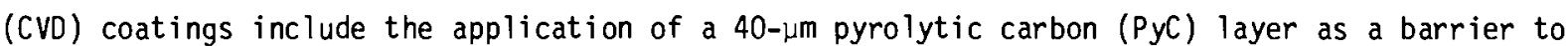
increase leach resistance and a $60-\mu \mathrm{m} \mathrm{Al}_{2} \mathrm{O}_{3}$ layer as a barrier to increase oxidation resistance. Glass coating of sintered-ceramics by frit and glaze, which is a less complex coating process, was also investigated. Although coatings offer increased inertness, a high level of technological complexity is also required.

Several approaches were explored at the Battelle-Columbus Laboratory in an effort to overcoat PyC-coated sintered-ceramic particles with a metal oxide. The Pyc coating was deposited from decomposition of $\mathrm{C}_{3} \mathrm{H}_{8}$ or $\mathrm{C}_{2} \mathrm{H}_{2}$ in a fluidized bed. The primary function of the PyC layer is to provide leach resistance in water. The metal-oxide coating protects the PyC layer from oxidation at elevated temperatures and also provides additional leach resistance.

\section{Fluidized-Bed Coatings of $\mathrm{PyC} / \mathrm{Al}_{2}{ }_{2}-3$}

In preliminary work, SPC-2 sintered pellets were overcoated with $\mathrm{PyC}$ and $\mathrm{Al}_{2} \mathrm{O}_{3}$ in a fluidized bed with $\mathrm{ZrO}_{2}$ diluent as an expedient way of supplying materials for testing. This method yielded good-quality $\mathrm{Al}_{2} \mathrm{O}_{3}$ and $\mathrm{PyC}$ coatings on $20 \mathrm{~g}$ g beds of particles, but the $\mathrm{Al}_{2} \mathrm{O}_{3}$ coatings were only successful when the particle size was less than $2 \mathrm{~mm}$. The modifications necessary to extend this process to beds of more economical size containing larger particles $(>2 \mathrm{~mm})$ were not justified in comparison to simpler approaches. Consequently, the application of $\mathrm{Al}_{2} \mathrm{O}_{3}$ coatings in a drum coater were explored.

\section{Drum-Coating}

Good-quality protective coatings were obtained by drum-coating. The procedure first involved overcoating the $\mathrm{PyC}$ with $\mathrm{SiO}_{2}$, which then protected the PyC layer during 
application of an impervious layer of $\mathrm{Al}_{2} \mathrm{O}_{3}$. The negative feature of this approach was that two chemically different oxide layers were required. Because of this complication in the drumcoating system, a vibrating-bed system was examined.

\section{Alumina Overcoating of $\mathrm{PyC}$ in a Vibrating Bed}

Alumina overcoating in a vibrating bed of Pyc-coated sintered-ceramic cores (2- to 3-mm) was successfully applied to beds of $\sim 100 \mathrm{~cm}^{3}$. This method was used to overcoat $\sim 1100 \mathrm{~cm}^{3}$ of PyC-coated sintered-ceramic cores for matrix encapsulation tests. The PyC coatings had been applied previously by the fluidized-bed method.

\section{Laboratory-Scale Production of Inert Glass Coatings}

Two techniques to produce inert glass coatings were examined on a laboratory scale. In both cases a coating material of glass frit or glaze slip was applied to sintered-ceramic spheres at room temperature and heated to form a continuous glass coating over the sphere surface.

In the first technique a ground frit coating up to $1 \mathrm{~mm}$ thick was applied to sinteredceramic spheres $5 \mathrm{~mm}$ to $10 \mathrm{~mm}$ in dia using the disc pelletizer. The technique was similar to that used in the pharmaceutical industry to coat pills. The sintered pellets were placed in the rotating pelletizer, and a quantity of frit and a fine water spray were simultaneously added.

In the second technique, spraying or dipping methods were used to apply the glaze slip to sintered spheres. While spraying has considerable process advantages and was quite promising, it required tight control of slip properties. Dipping is a more complex process, but it was not as sensitive to the fluctuating slip properties that were encountered. Good-quality glass coatings were produced by both options. Scaleup of such processes to a remote scale may be difficult, however.

\section{Metal-Matrix Development}

Two types of processes were considered for the encapsulation of solidified HLW: sinteredmetal powders and vacuum-cast alloys. Selection of these processes is based on the compatibility of different metals with the advanced waste particle forms, the ease of the encapsulation process, and the optimization of high thermal conductivity, impact strength, and corrosion resistance.

\section{Sintered-Metal Powder}

Sintered-metal powders are considered to be prime candidates for use as metal matrices with sintered-ceramic pellets. This combination allows high levels of heat generation and the highest allowable fabrication and storage temperatures. The primary reason for considering sintered matrices is that metals with high melting points can be employed (e.g., copper, bronze, stainless steels, etc.). The potential loss of a matrix during a high-temperature accident is thus reduced. Sintering also lends itself well to remotely operated fabrication facilities because the process is fairly simple. 
Since sintered matrices are formed from near-spherical metal particles, final matrix densities range from $\sim 40 \%$ to $\sim 65 \%$ of theoretical density. Compared to the cast, $100 \%$-dense metal matrices, sintered matrices may not offer the optimum leach protection and thermal conductivity because of the interconnecting porosity of the sintered matrix.

\section{Vacuum-Cast Al loys}

Vacuum-cast alloys are considered to be prime candidates for matrix encapsulation of waste-glass marbles and glass-coated or uncoated sintered-ceramics. Fabrication temperatures for the glass marble and glass-coated sintered-ceramic waste forms are limited by the softening points of the glasses, which are $\sim 600^{\circ} \mathrm{C}$. Uncoated sintered-ceramics can have a fabrication temperature limit of $1200^{\circ} \mathrm{C}$, which is above the casting temperature of some candidate metalmatrix materials. Vacuum-cast matrices have many advantages over the sintered matrices, since the matrix will be cast at $100 \%$ density.

Lead, lead alloys, aluminum and aluminum alloys are the best candidates for vacuum-cast matrices because of fabrication temperature restrictions and their relatively low melting temperatures. Aluminum and its alloys have higher thermal conductivity values, higher melting points, and greater strengths than do the lead alloys but may have lower long-term chemical durabilities. Although a greater density of lead provides increased radiation shielding, the increased weight may add some difficulty in handling and transporting the canisters.

\section{ONE-LITER DEMONSTRATIONS}

Four multibarrier concepts were demonstrated on a one-liter scale: 1) glass marbles in a lead-tin matrix, 2) sintered supercalcine pellets in an aluminum-silicon matrix, 3) sintered supercalcine pellets coated with glass in an aluminum-silicon matrix, and 4) supercalcine pellets coated with pyrolytic carbon and aluminum oxide in a copper matrix. The development and characterization of these concepts has been described elsewhere (Rusin et al. 1978; McCarthy 1977; Floyd and Engelleitner 1967; Chapman 1976; Knapp and Smith 1962; Rusin, Lokken and Wald 1979b).

In general, proposed waste form processes have properties that fall within a narrow range (Rusin 1978). Process complexity and feasibility therefore become important parameters.

Based upon the development and characterization studies at PNL, several conclusions can be made:

- Sintering and vacuum-casting are both applicable methods for metal-matrix encapsulation.

- The multibarrier concept of glass marbles being encapsulated in a vacuum-cast lead alloy provides improved inertness with the smallest increase in technological complexity.

- If it were desirable to develop a crystalline multibarrier waste form, uncoated sintered-ceramic pellets would require a much lower level of technological complexity than would glaze- or CVD-coated pellets. 
- The 16-in.-dia pelletizer unit has enough capacity to handle the output of a large PNL spray calciner ( $50 \mathrm{~kg}$ calcine/h) and it can form spray-calcined material into 2- to 20-mm-dia pellets that are strong enough to withstand handling without significant break age.

- Chemical-vapor-deposition coating of sintered-ceramics should be pursued only if a very high level of inertness is required. 


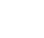

. 


\section{PRIMARY WASTE FORM CANISTER}

S. C. Slate

Waste forms are generally contained within a metallic canister. This canister has the primary function of containing the waste form and facilitating handling during processing, interim storage and disposal. It is not currently viewed as a long-term barrier in the repository. The development and selection of materials for use as a long-term (>1000-yr) containment has begun, but the data is not included in this year's report because of its preliminary nature.

The waste form canister is a significant part of the waste package, and interactions between it and the waste form have been evaluated and discussed in earlier documents (Slate and Ross 1977, Slate et al. 1978). The majority of experience with canisters has been related to the containment of waste glass. Criteria for waste canister design are currently being developed as part of the Commercial Waste Packaging studies. A preliminary draft of these criteria is available (Moore 1978). The criteria address the matters of licensing, physical dimensions, radiation limits and quality control.

Reference canister designs have been developed at PNL for both the in-can melting (ICM) and continuous melting (CM) processes. The basic design consists of a single-wall pipe with a flat, flanged bottom. The top will probably also be flat, though it may be domed on largediameter canisters. The top of the canister has a carefully designed opening that couples with the vitrification equipment and allows for a reliable final closure.

The diameter of the canister will range from $30 \mathrm{~cm}$ to $91 \mathrm{~cm}$, and its length will be about 3 meters. The canisters are currently made of either stainless or carbon steels. The current reference stainless-steel alloys are 304L and Incone1-601, though other alloys are also being studied. Figure VI.1 shows the current PNL reference designs for ICM and CM canisters. These designs are intended for low-heat wastes. The ICM canister has internal fins that are utilized to achieve the high melting rates desired for large-scale production rates. Fins can also be used in either design for improved heat transfer through the glass when using high-heat wastes.

The research at PNL on waste canisters is directed toward three main areas. The first is technology development, which is where the basic data and analytical techniques necessary to design a canister are developed. The second is testing of full-scale canisters using prototype vitrification equipment. The third is canister processing development, which involves the study of canister-handling operations.

\section{TECHNOLOGY DEVELOPMENT}

We are determining basic design properties of potential canister materials and analytical methods for predicting canister performance. Capabilities for predicting thermal and structural performance have already been developed. 


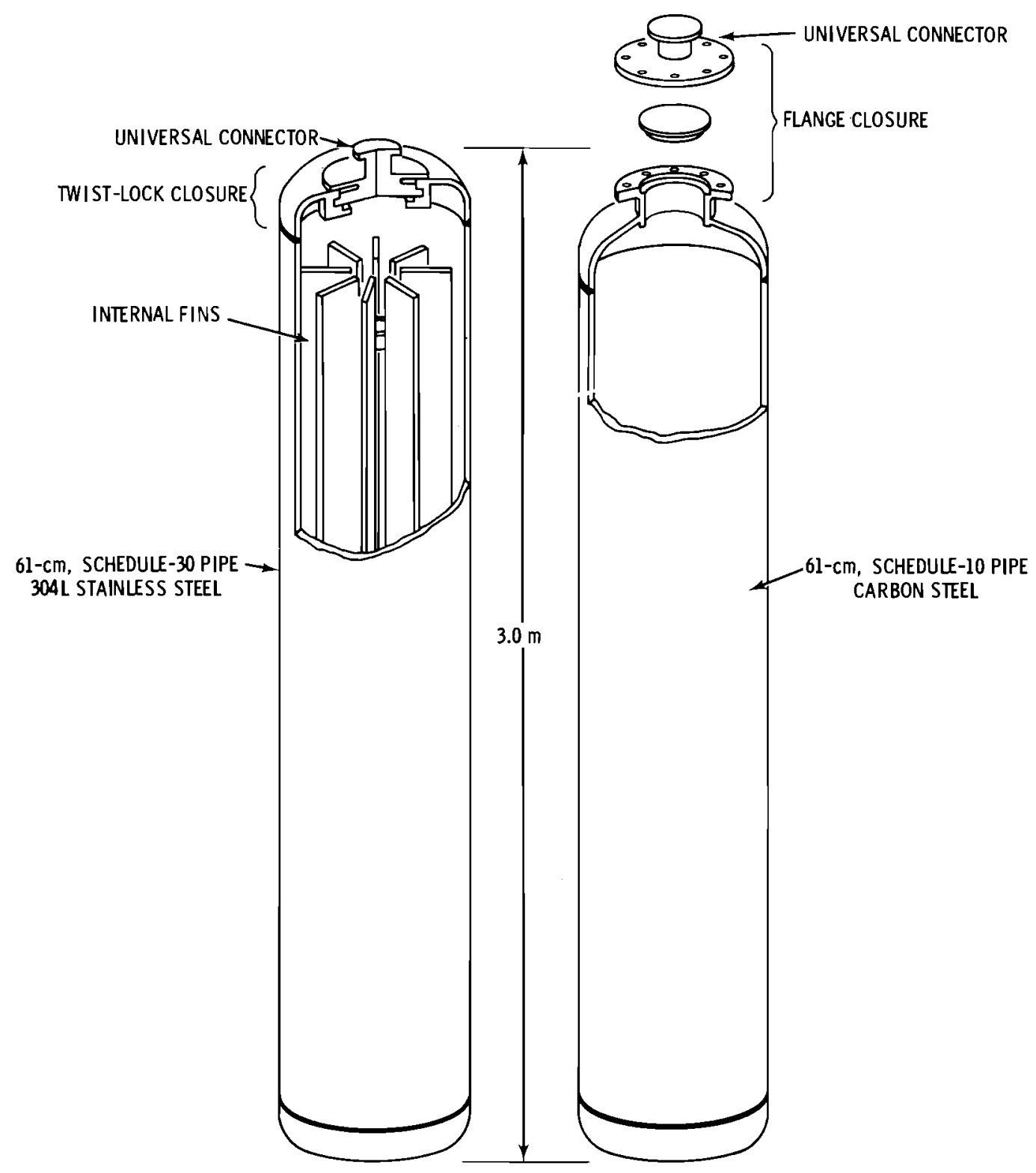

FIGURE VI.1. Two Reference ICM Canister Designs

\section{Materials}

The evaluation of materials is one of the most important development activities. We are studying several material properties: strength (over a temperature range of $100^{\circ}$ to $1150^{\circ} \mathrm{C}$ ), corrosion resistance, ease of fabrication, cost, and long-term stability. The major areas of study have been concerned with corrosion resistance and material strength. The corrosion rates of several canister materials in different glass compositions have been reported (Slate and Maness 1978). Work has continued subsequent to that report using new glass compositions. We have measured the strength of 304L and Inconel-601 at temperatures 
between $900^{\circ} \mathrm{C}$ and $1150^{\circ} \mathrm{C}$ and have reported the data (VanEcho and Simonen 1978). These data on high-temperature strength are necessary in predicting the performance of the canister during the ICM process.

\section{Stress Analys is}

A document summarizing all the stress analyses conducted on the primary storage canister over the last several years has been recently completed (Simonen and Slate 1977). The subject of the report is the structural integrity of waste canisters during processing, handling, interim storage, and transportation.

We have analyzed stresses in canisters and evaluated integrity under projected service loadings. The loadings canisters experience are from lifting and handling, internal pressure, high-temperature filling operations, transient heating and cooling, the differential in thermal expansion coefficients of the canister and glass, and impact loadings from low-probability accidents. Case studies are included that analyze these service loadings, illustrate applicable stress analys is methods, show preferred design approaches, and provide useful engineering design data.

\section{Thermal Analys is}

The prediction of the thermal performance of the glass/canister system is important in assuring glass quality and canister integrity and in making design judgments. Early work on the thermal analysis of canisters was reported in the first Waste Fixation Program annual report (Mendel et al. 1977). Since that time we have improved the computer model and have correlated its results with experimental data.

An advanced 2-D computer model was developed at PNL to explicitly model the cross section of a canister containing internal fins. The model is very flexible and can predict canister temperatures under a wide variety of conditions.

A new area in our thermal analysis work is the interpretation of empirical temperature data from full-scale canister tests. We are using this data to evaluate the accuracy of our computer model. One of the biggest questions about the accuracy of our model is how well it can predict the thermal performance of cracked glass that is found in the large canisters. So $f a r$, preliminary results indicate that cracking does not significantly affect the transfer of heat from the glass to the outside.

A brief discussion of the computer model and the analysis of empirical data is presented in a paper by wescott and Slate (1979).

\section{FULL-SCALE TESTING}

The data from the technology development task is used to design full-scale canisters. These canisters are then filled with glass using the full-scale vitrification equipment. The goal of these tests is to verify the performance of the canister under normal and accident conditions. Full-scale testing of vitrification equipment has been conducted on a regular 
basis at PNL since 1977. To date, 25 canisters have been filled by the ICM process and 50 canisters have been filled by the " process. These canisters have ranged from 30 to $91 \mathrm{~cm}$ in dia and from 2.1 to $3.0 \mathrm{~m}$ in length.

During these tests we gather data on the performance of the canister. Temperature data are the most important kinds of information to be gained, because they are useful in predicting corrosion and mechanical deformation and in understanding the final chemical and mechanical condition of the glass. Both absolute temperatures and temperature gradients are measured on the canister and in the glass.

\section{Temperature Data}

An example of the data taken is shown in Figure VI.2. This figure shows the radial temperature profile in a $60-\mathrm{cm}-\mathrm{dia}$ canister as a function of time. This information is useful in estimating cracking and in analyzing the condition of the glass. We are now analyzing the large volume of data we have accumulated from all the full-scale tests.

\section{Canister Corrosion and Deformation}

We have evaluated corrosion and mechanical deformation. Corrosion of the canister is measured by examining a sample of the actual canister wall. Canister distortion is determined by finding the change in canister diameter at various heights. In general, insignificant distortion is seen in CM canisters, and there is only an increase of $\sim 1 \%$ in the diameter of an ICM canister. Two major full-scale tests are described by Chapman (1979) and McElroy et al. (1979b).

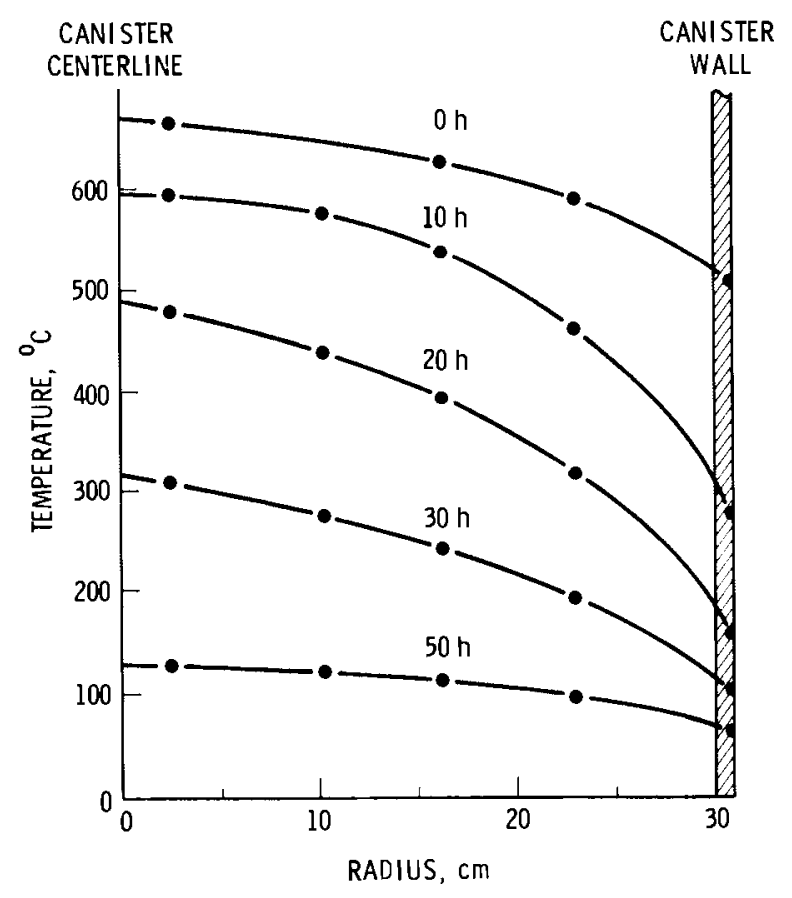

FIGURE VI.2. Radial Temperature Profiles of a 60-cm-dia Ceramic Melter Canister of Glass as a Function of Time 


\section{Impact Tests}

Full-scale canisters have been used in evaluating canister performance in impact tests. A total of 13 canisters that ranged from $30 \mathrm{~cm}$ to $60 \mathrm{~cm}$ in dia were dropped from heights ranging from $6 \mathrm{~m}$ to $30 \mathrm{~m}$ (McElroy et al. 1979c). The drop-test results are discussed by Simonen and Slate (1977). These authors conclude that canisters of simple design can sustain severe impacts to the bottom or side. The effect the impact has on the glass is discussed in Section $x$.

\section{Canister Overheat Test}

We have also simulated a loss-of-cooling accident that might occur during the ICM process. The most serious ICM accident possible would have a canister overheating as a result of the self-heating nature of the glass. In this test we evaluated the canister performance and the effect high temperature has on the glass. Temperatures were measured for correlation with the heat transfer computer model. To simulate the internal heat generation, we used direct joule-heating of the fins inside a 20 -cm-dia canister.

A maximum power input of $25 \mathrm{~kW}$ was used during the test. At this level the canister reached a maximum temperature of $900^{\circ} \mathrm{C}$ and the glass reached an average of $1350^{\circ} \mathrm{C}$. The glass near the fins probably reached about $1450^{\circ} \mathrm{C}$, but this was not confirmed by a direct measurement. The test ended when an internal fin failed because of corrosion. The most important result from this test is that even at these elevated temperatures the glass was not significantly altered, and there was no sign of a reboil phenomenon. Nor were any significant effects noted on the canister.

\section{CANISTER PROCESSING OPERATIONS}

The major processing operations that a waste canister must experience going from fabrication through to terminal storage are being studied. Fourteen major operations have been identified. We have already demonstrated several of these process steps: filling and cooldown with the full-scale equipment and canisters, seal-welding, and helium leak inspection of our twist-lock lid closure (McElroy et al. 1979d). A full-scale water storage experiment to test the long-term corrosion behavior of prototypic (although nonradioactive) canisters of glass is in progress. Canisters are stored in $1-$ to $1000-\mathrm{ppm}$ chloride water at $50^{\circ}$ to $80^{\circ} \mathrm{C}$. No significant effects have been observed after the first 8 mo of water storage. 


\section{LEACHING STUDIES}

J. H. Westsik, Jr., D. J. Bradley, Y. B. Katayama, R. P. Turcotte

During 1978 the scope of the leaching studies at PNL continued to broaden. In addition to leach-testing of glass done in support of the HLWIP development and characterization activities, testing of alternative waste forms and spent fuel is under way. The long-term testing of spent fuel originated in the Waste Fixation Program (WFP), and this year continued under the Waste Isolation Safety Assessment Program (WISAP). The WISAP is also investigating the behavior of HLW glass in environments simulating geologic repositories.

\section{GLASS LEACHING}

Long-term leach tests continue as an integral part of the glass characterization studies. High-temperature tests were initiated to accelerate the leaching process so that the future leaching behavior of the glass can be estimated.

\section{Long-Term Leach Tests}

Long-term leach tests are used for two reasons: 1) to quantify the leaching process, and 2) to characterize the effects of thermal treatment or radiation exposure on the glass. Typically, a modified IAEA leach test is used (Mendel et al. 1977). Table VII.1 lists the latest leach rates measured for crushed samples of the four simulated commercial power waste glasses $(72-68,76-68,77-107,77-260)$ leached in $25^{\circ} \mathrm{C}$ deionized water. These bulk glass leach rates based on $\mathrm{Cs}$ and $\mathrm{Sr}$ continue to decrease with time. Part of the decrease for the 76-68 and 72-68 glasses may be a result of an increase in the leaching period from 28 to $180+d$, as discussed in PNL-2625 (Ross et al. 1978). As shown in Figure VII.1, after more than $1000 \mathrm{~d}$ of leaching the leach rates of 72-68 glass continue to decrease in a completely static system, as compared to a system where the leachant is changed according to the IAEA method.

In another test we determined how changes in cesium and strontium concentration in 76-68 glass can affect the leach rate. Samples of 76-68 glass in which the cesium and strontium concentrations varied by factors of $0.1,0.5,1.0,2.0,5.0$ and 10.0 from the defined concentrations were leached using the modified IAEA procedures. Leach rates based upon cesium releases from the crushed glass are plotted in Figure VII.2. These are average leach rates over the time from 7 through $119 \mathrm{~d}$ of exposure to $25^{\circ} \mathrm{C}$ deionized water. In the range from 0.5 to 5.0 times the defined concentrations, leach rates remain constant. This means that

TABLE VII.1. Latest Long-Term Leach Rates of Four Simulated HLW Glasses

\begin{tabular}{|c|c|c|c|c|}
\hline \multirow[b]{2}{*}{ Glass } & \multirow{2}{*}{$\begin{array}{l}\text { Total Time } \\
\text { Leached, d }\end{array}$} & \multirow{2}{*}{$\begin{array}{c}\text { Latest } \\
\text { Leaching } \\
\text { Interval, d } \\
\end{array}$} & \multicolumn{2}{|c|}{$\begin{array}{c}\text { Leach Rate, } \\
\mathrm{g} \text { glass } / \mathrm{cm}^{2}-\mathrm{d} \\
\text { (based on } \mathrm{Cs} \text { and } \mathrm{Sr} \text { ) }\end{array}$} \\
\hline & & & Cs & $-\mathrm{Sr}$ \\
\hline $72-68$ & 1173 & 184 & $5 \times 10^{-8}$ & $7 \times 10^{8}$ \\
\hline $76-68$ & 596 & 183 & $6 \times 10^{-9}$ & $6 \times 10^{-9}$ \\
\hline $77-107$ & 230 & 28 & $6 \times 10^{-9}$ & $3 \times 10^{-7}$ \\
\hline $77-260$ & 231 & 28 & $2 \times 10^{-8}$ & $6 \times 10^{-8}$ \\
\hline
\end{tabular}




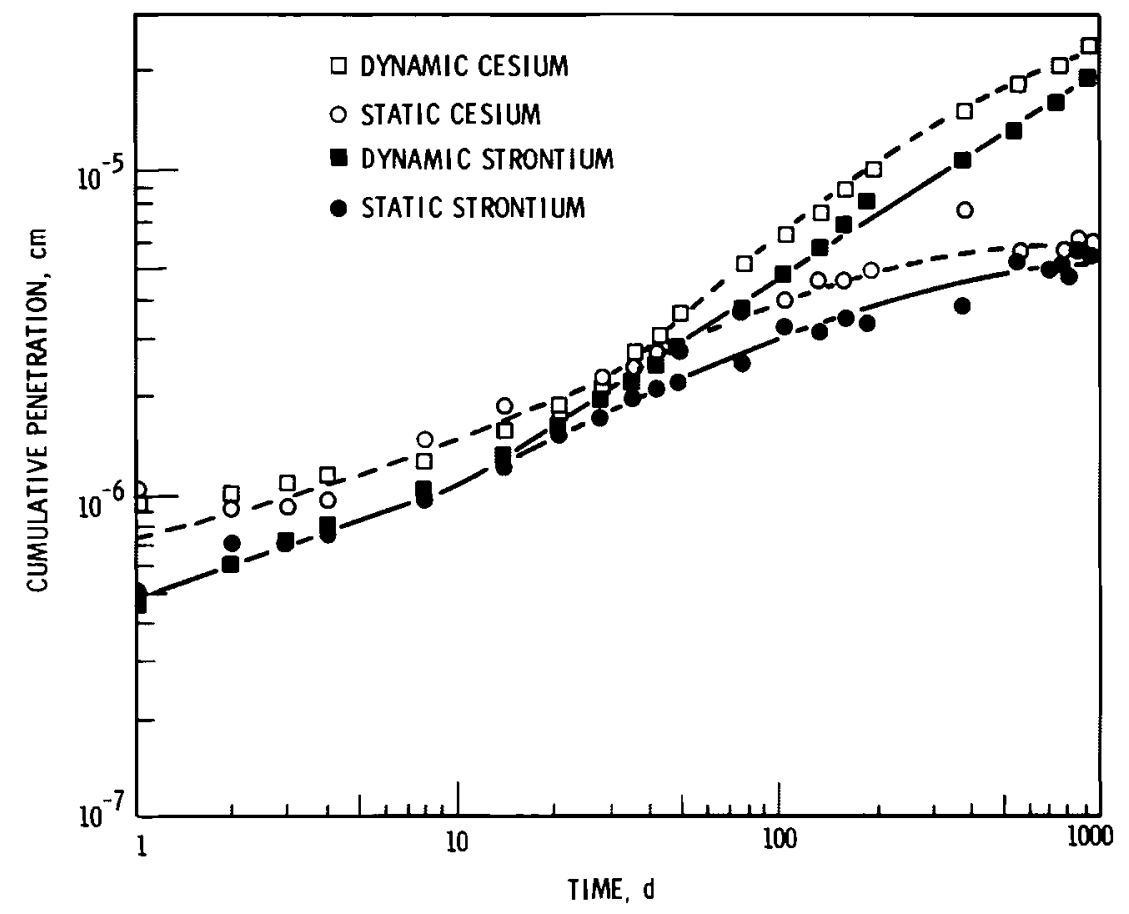

FIGURE VII.1. Comparison of Static and IAEA Leach Test Results

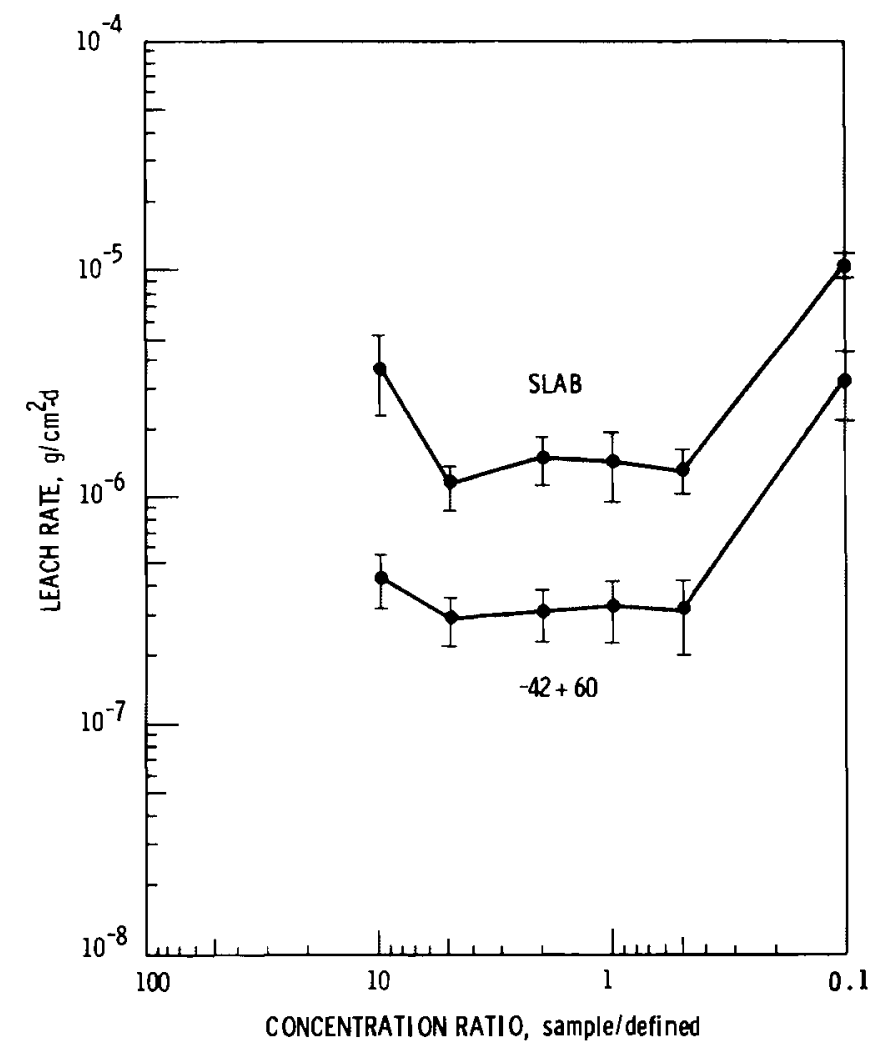

FIGURE VII.2. Leach Rates of 76-68 Glass Based on Cesium as a Function of the Cesuim Concentration in the Glass 
more cesium and strontium are released from the glasses that contain higher concentrations of them. However, the fraction released of each element (and therefore the leach rate) remains constant. The changes in the glass composition at 0.1 and 10.0 times the defined $\mathrm{Cs}$ and $\mathrm{Sr}$ loadings changed the glass structure such that the leach rates increase at these extremes. It also emphasizes that reduced waste loadings will not necessarily reduce the leach rate of the glass: glasses 72-68 and 77-107 have higher leach rates than do 76-68 and 77-260.

Both the Soxhlet and the long-term leach tests are used to evaluate the changes in chemical durability of a glass due to long-time thermal anneals. Figures VII.3 and VII.4 show average long-term leach rates of 77-107 and 77-260 glasses based on their releases of cesium and strontium. Before leaching, the samples were stored in air at a series of temperatures between $300^{\circ}$ and $900^{\circ} \mathrm{C}$ for 60 days. After quenching, the samples were crushed to -42 and 60 mesh before the $25^{\circ} \mathrm{C}$ test. The figures show average leach rates from 22 through $231 \mathrm{~d}$ as a function of the storage temperature. The two glasses show only minor changes in leachability resulting from the thermal treatments. Glass 77-260 does show a spike in its Sr-based leach rate at the $700^{\circ} \mathrm{C}$ storage temperature. When these curves are compared with Figure 17 in PNL-2625 (Ross et al. 1978), it is apparent that the glass composition typically has more influence on its leach rate than does the thermal treatment.

One-year storage samples of 77-107 and 77-260 glasses were tested using the 72-h Soxhlet test. Table VII.2 shows the results of these $99^{\circ} \mathrm{C}$ tests. These weight loss measurements should be compared with those for shorter storage times shown in Table 8 in PNL-2625 (Ross et al. 1978). While 77-260 glass is slightly more affected than is $77-107$, both glass formulations have very good thermal stabilities over the entire devitrification temperature range.

The WISAP program is using, among others, the long-term test to generate elemental release rate data specifically oriented toward geologic disposal conditions. Samples of 76-68 glass doped with tracer quantities of $\mathrm{TC}, \mathrm{Am}, \mathrm{U}, \mathrm{Pu}, \mathrm{Np}$, and $\mathrm{Cm}$ were leached in a salt brine, deionized water, and solutions of calcium chloride, sodium bicarbonate and sodium chloride. Figures VII.5 and VII.6 show leach rates of the glass based on ${ }^{239} \mathrm{Pu}$ releases. Curium and neptunium results follow the same trends. There is about a factor of 10 difference between the leach rates obtained in salt brine and in the bicarbonate solution. The other three solutions fall inside this band.

Hydrothermal Studies

Leaching studies of nuclear waste glasses have usually been conducted at or below $100^{\circ} \mathrm{C}$. We have extended these studies to higher temperatures so that we can: 1) provide accelerated test conditions, and 2) establish reaction rates over a broad temperature range. Many of the results presented here are discussed in more detail in PNL-2759 (Westsik and Turcotte 1978). Studies with a supercalcine and Cermet are discussed later in this section.

In these hydrothermal studies of 76-68 glass, a solid glass cylinder, some powdered glass, some powdered geologic material, and deionized water in the mass ratio 1:5:50:63 were reacted at $350^{\circ} \mathrm{C}$ for one and three weeks. The geologic material was either crushed salt or crushed Umtanum basalt. The temperature used is significantly higher than would be expected in a wet repository. It was used in these tests only to accelerate the rates of reactions. 


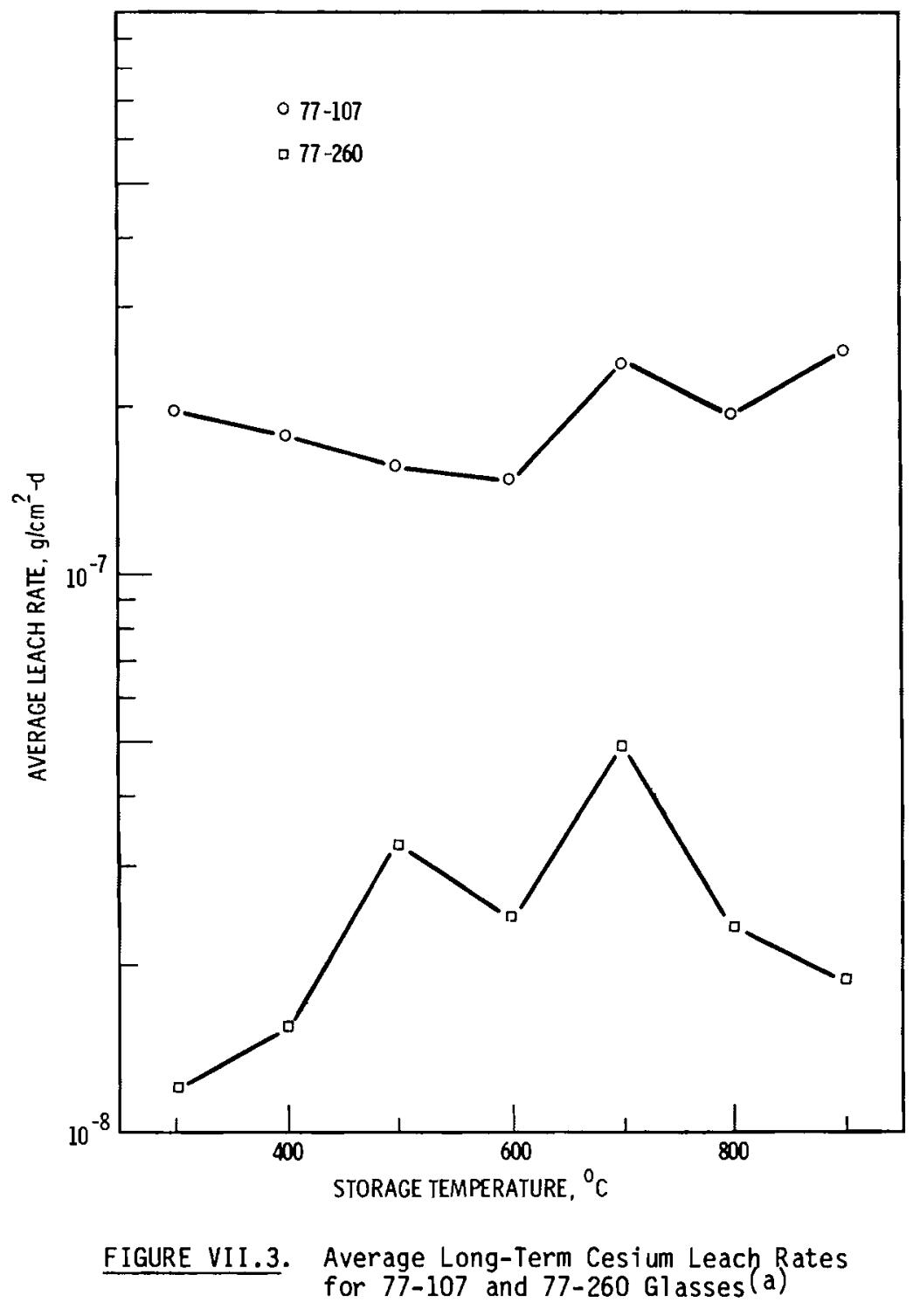

(a) Samples stored two months.

The waste glass undergoes various levels of crystallization, depending upon the exposure conditions. The primary reconstruction product is $\mathrm{NaFeSi}_{2} \mathrm{O}_{6}$. Metallographic examination of the glass cylinders reveals that the rate of alteration is highest in deionized water, followed by the basalt system and finally the salt brine. However, Table VII.3 shows that under equivalent test conditions much more cesium, rubidium and strontium are released from the powdered glass to the salt brine than are released to deionized water or the basalt system. Releases 


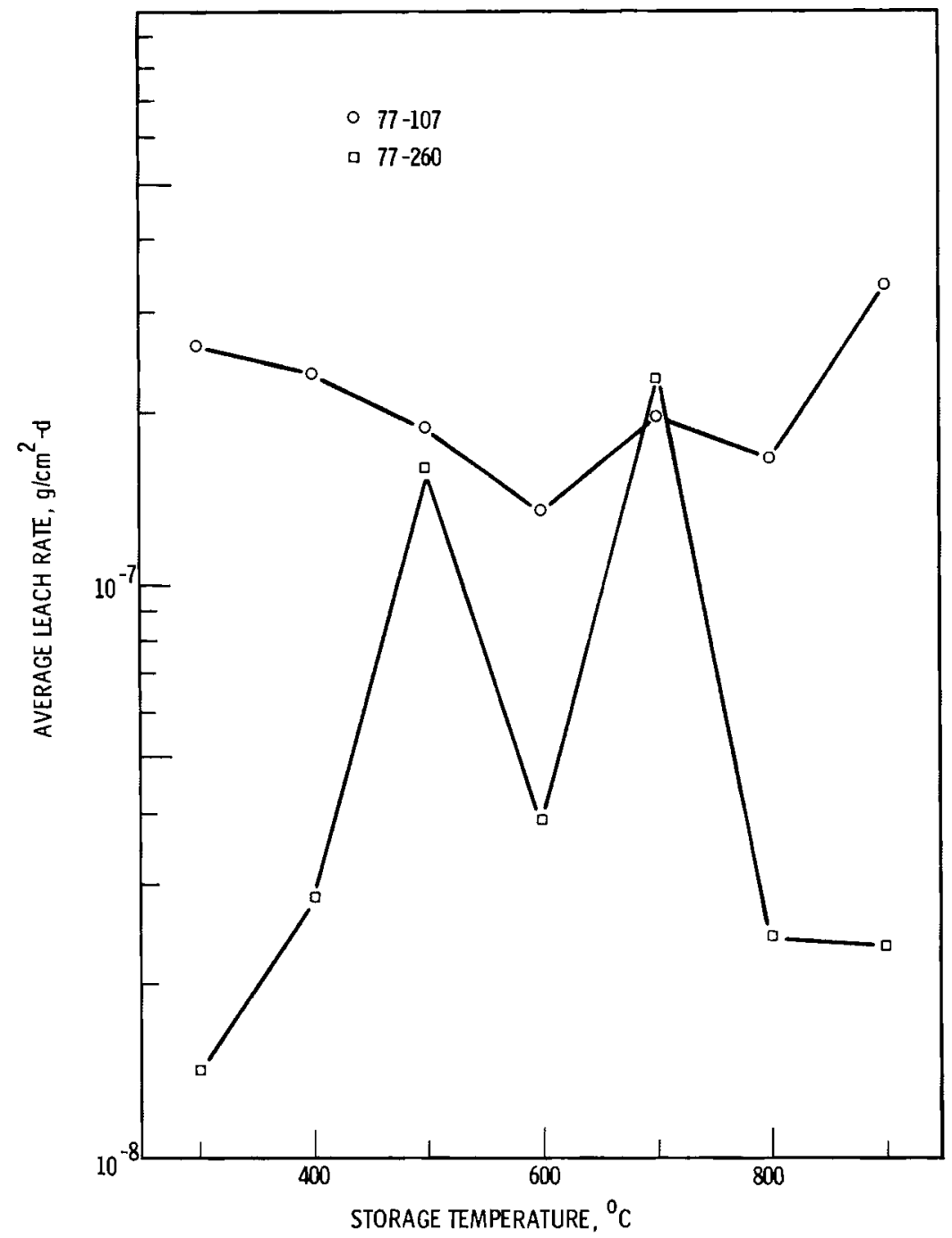

FIGURE VII.4. Average Long-Term Strontium Legach Rates for 77-107 and 77-260 G1 asses $(a)$

(a) Samples stored two months.

were lowest in the basalt system, through some of the ions leached from the glass may have reprecipitated on the glass or may have reacted with the basalt as it also altered. Since the solution concentrations are relatively constant between the 7-d and 21-d tests in salt brine or deionized water, the leaching of the glass is apparently being limited by solubility of the leached elements in these systems. 
TABLE VII.2. Soxhlet Leach Data for Standar (filasses After One-Year Thermal Storage (a)

\begin{tabular}{|c|c|c|}
\hline $\begin{array}{c}\text { Storage } \\
\text { Temperat ure, } \\
{ }^{0} \mathrm{C} \\
\end{array}$ & $\begin{array}{l}\text { Glass } \\
77-107\end{array}$ & $\begin{array}{l}\text { Glass } \\
77-260\end{array}$ \\
\hline 300 & 1.93 & 3.07 \\
\hline 400 & 3.11 & 3.50 \\
\hline 500 & 2.87 & 2.77 \\
\hline 550 & 2.08 & 2.79 \\
\hline 600 & 2.69 & 2.21 \\
\hline 650 & 3.35 & 2.50 \\
\hline 700 & 3.16 & 4.00 \\
\hline 750 & 2.37 & 3.88 \\
\hline
\end{tabular}

(a) Leach rate in percent weight loss in $72 \mathrm{~h}$; convert to $\mathrm{g} / \mathrm{cm}^{2}-\mathrm{d}$ by multiplying by $1.28 \times 10^{-5}$.

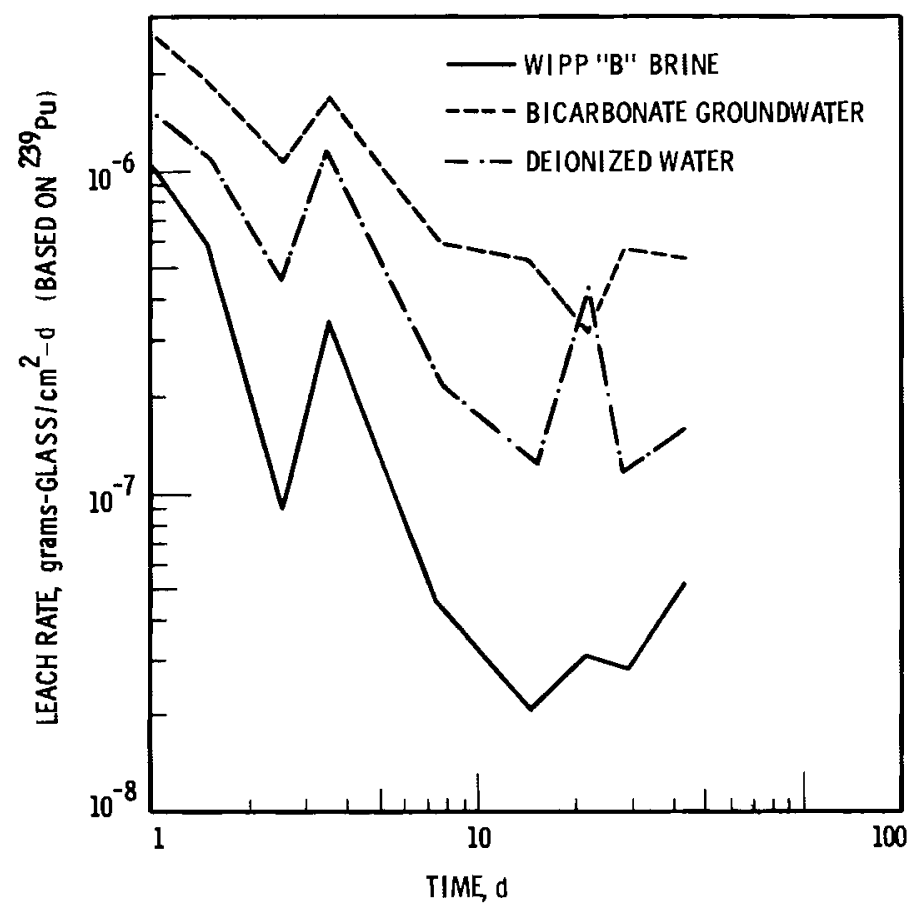

FIGURE VII.5. Long-Term Leach Test Results in Brine, Bicarbonate and Deionized Waters 


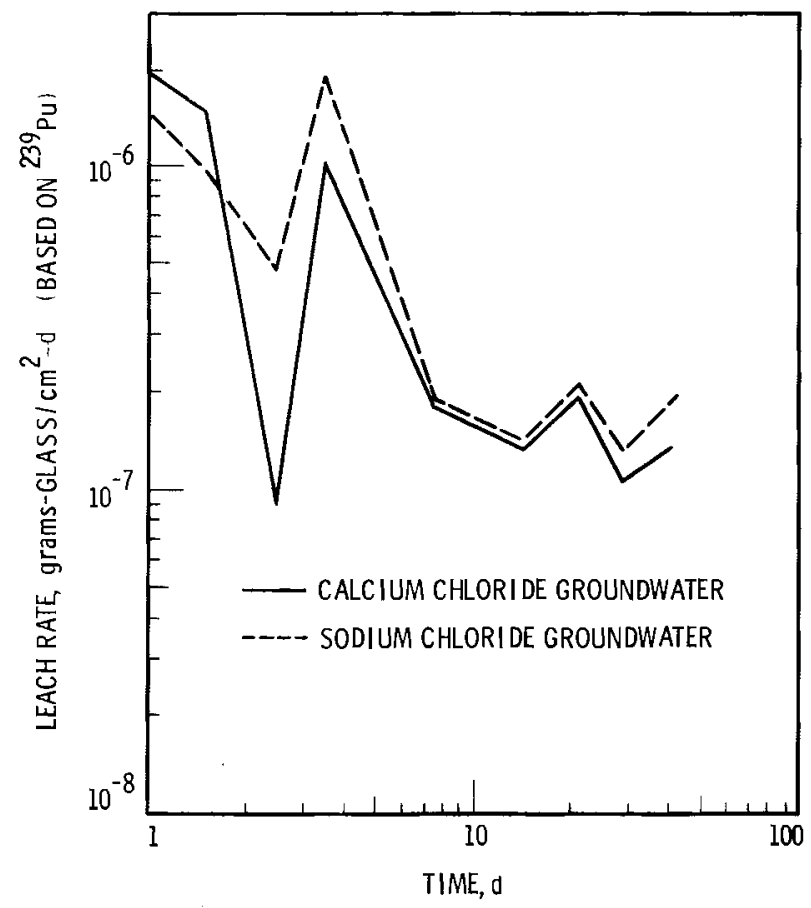

FIGURE VII.6. Long-Term Leach Rates in $\mathrm{CaCl}_{2}$ and $\mathrm{NaCl}$ Solutions

TABLE VII.3. Hydrothermal Leach Test Results for 76-68 Giass

\begin{tabular}{|c|c|c|c|c|c|c|c|c|c|c|}
\hline \multirow{3}{*}{$\begin{array}{l}\text { Solution } \\
\text { Brine }\end{array}$} & \multirow{2}{*}{$\begin{array}{c}\text { Time, } \\
\mathrm{d}\end{array}$} & \multirow{2}{*}{$\begin{array}{l}\text { Leach Rate Based } \\
\text { on weight Loss, } \\
\mathrm{g} / \mathrm{cm}^{2-d} \mathrm{~d}(\mathrm{a}) \\
\end{array}$} & \multicolumn{8}{|c|}{$\begin{array}{c}\text { Concentration of Element in Solution, } \mathrm{mg} / \mathrm{l}(\mathrm{b}) \\
(\% \text { released in parentheses })\end{array}$} \\
\hline & & & Cs & $\mathrm{Rb}$ & $S^{3 x}$ & Mo & si & 8 & 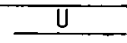 & $2 n$ \\
\hline & 7 & $4.0 \times 10^{-3}$ & $\begin{array}{l}650 \\
(66)\end{array}$ & $\begin{array}{l}87 \\
(72)\end{array}$ & $\begin{array}{l}11.6 \\
(3.6)\end{array}$ & $\begin{array}{l}830 \\
(54)\end{array}$ & $\begin{array}{l}35 \\
(0.2)\end{array}$ & $\begin{array}{l}2100 \\
(71)\end{array}$ & $\begin{array}{l}1.5 \\
(<0.1)\end{array}$ & $\begin{array}{l}21 \\
(0.5)\end{array}$ \\
\hline Brine & 7 & $4.6 \times 10^{-3}$ & $\begin{array}{l}760 \\
(80)\end{array}$ & $\begin{array}{l}96 \\
(82)\end{array}$ & $\begin{array}{l}10.6 \\
(3.4)\end{array}$ & $\begin{array}{l}880 \\
(59)\end{array}$ & $\begin{array}{l}33 \\
(0.2)\end{array}$ & $\begin{array}{l}2100 \\
(73)\end{array}$ & $\begin{array}{l}0.2 \\
(<0.1)\end{array}$ & $\begin{array}{l}10 \\
(0.3)\end{array}$ \\
\hline Brine & 21 & $4.5 \times 10^{-3}$ & $\begin{array}{l}990 \\
(95)\end{array}$ & $\begin{array}{l}115 \\
(90)\end{array}$ & $\begin{array}{l}16.5 \\
(4.8)\end{array}$ & $\begin{array}{l}1010 \\
(62)\end{array}$ & $\begin{array}{l}47 \\
(0.2)\end{array}$ & $\begin{array}{l}3000 \\
(96)\end{array}$ & $\begin{array}{l}0.5 \\
(<0.1)\end{array}$ & $\begin{array}{l}13 \\
(0.3)\end{array}$ \\
\hline Brine & 21 & (c) & $\begin{array}{l}650 \\
(70)\end{array}$ & $\begin{array}{l}111 \\
(96)\end{array}$ & $\begin{array}{l}10.4 \\
(3.4)\end{array}$ & (c) & $\begin{array}{l}24 \\
(0.1)\end{array}$ & $\begin{array}{l}2500 \\
(89)\end{array}$ & $\begin{array}{l}6.3 \\
(0.2)\end{array}$ & $\begin{array}{l}23 \\
(0.6)\end{array}$ \\
\hline $\begin{array}{l}\text { Deionized } \\
\text { Water }\end{array}$ & 7 & $5.3 \times 10^{-3}$ & $\begin{array}{l}65 \\
(6)\end{array}$ & $\begin{array}{l}20 \\
(16)\end{array}$ & $\begin{array}{l}0.63 \\
(0.2)\end{array}$ & $\begin{array}{l}780 \\
(49)\end{array}$ & $\begin{array}{l}420 \\
(2.2)\end{array}$ & $\begin{array}{l}3400 \\
(100)\end{array}$ & $\begin{array}{l}4.8 \\
(0.1)\end{array}$ & $\begin{array}{l}0.33 \\
(<0.1)\end{array}$ \\
\hline $\begin{array}{l}\text { Deionized } \\
\text { Water }\end{array}$ & 21 & $4.0 \times 10^{-3}$ & $\begin{array}{l}37 \\
(4)\end{array}$ & $\begin{array}{l}24 \\
(20)\end{array}$ & $\begin{array}{l}1.27 \\
(0.4)\end{array}$ & $\begin{array}{l}940 \\
(63)\end{array}$ & $\begin{array}{l}340 \\
(1.9)\end{array}$ & $\begin{array}{l}2500 \\
(86)\end{array}$ & $\begin{array}{l}8.5 \\
(0.2)\end{array}$ & $\begin{array}{l}1.6 \\
(<0.1)\end{array}$ \\
\hline $\begin{array}{l}\text { Basalt } \\
\text { System }\end{array}$ & 7 & (c) & $\begin{array}{l}2.2 \\
(0.10)\end{array}$ & $\begin{array}{l}0.30 \\
(0.12)\end{array}$ & $\begin{array}{l}0.48 \\
(0.07)\end{array}$ & $\begin{array}{l}55 \\
(1.7)\end{array}$ & $\begin{array}{l}25 \\
(0.06)\end{array}$ & $\begin{array}{l}160 \\
(2.5)\end{array}$ & $\begin{array}{l}0.34 \\
(0.0004)\end{array}$ & (c) \\
\hline $\begin{array}{l}\text { Basalt } \\
\text { System }\end{array}$ & 21 & (c) & $\begin{array}{l}0.82 \\
(0.04)\end{array}$ & $\begin{array}{l}0.15 \\
(0.06)\end{array}$ & $\begin{array}{l}0.31 \\
(0.05)\end{array}$ & $\begin{array}{l}1.6 \\
(0.05)\end{array}$ & $\begin{array}{l}27 \\
(0.07)\end{array}$ & $\begin{array}{l}360 \\
(5.9)\end{array}$ & $\begin{array}{l}0.12 \\
(0.002)\end{array}$ & (c) \\
\hline
\end{tabular}

(a) Weight loss of a cylinder of material divided by its geometric surface area and time.

(b) Each test included roughly $20 \%$ by weight of a solid cylinder and $80 \%-325$ mesh powder. The majority of ions in solution were leached from the powder.

(c) Not available. 


\section{ALTERNATIVE WASTE FORMS}

Supercalcine

In autoclave tests similar to those for 76-68 glass, supercalcine has been exposed to hydrothermal conditions. Twelve grams of SPC-4 supercalcine powder, a hot-pressed pellet, and a sintered pellet of supercalcine were reacted with $150 \mathrm{ml}$ of deionized water at $350^{\circ} \mathrm{C}$ for 21 days. In one test, $120 \mathrm{~g}$ of crushed $\mathrm{NaCl}$ were included to give a saturated salt brine solution.

Table VII.4 lists the results of the solution analyses for these tests in salt brine and deionized water. Also included are data from a 3-d test shown originally in Table 3 of PNL-2759 (Westsik and Turcotte 1978). The concentrations of Cs, Rb and Sr released to the salt brine are higher from supercalcine than from the 76-68 glass discussed earlier. However, since SPC-4 supercalcine has a higher fission-product loading than does the glass $(63.2 \%$ vs. 12.8\%), the fraction of these fission products in solution is comparable for the two waste forms. Solution concentrations in deionized water are generally lower than are concentrations in salt brine.

We were able to obtain only one weight loss measurement from the hot-pressed and sintered pellets. The hot-pressed pellet treated $21 \mathrm{~d}$ in deionized water showed a weight loss rate of $6.2 \times 10^{-4} \mathrm{~g} / \mathrm{cm}^{2}-\mathrm{d}$. The other pellets either broke as they were removed from the autoclave, or else some of the loose powder reacted and adhered to the pellet surface.

Figure VII.7 shows cross sections of the four pellets. Despite the large releases to the salt brine, the hot-pressed and sintered pellets from these tests do not appear to have an alteration layer. The pellets treated in deionized water do show an alteration layer, although the thicknesses are not constant. The maximum thickness is $0.075 \mathrm{~cm}$ for both the hot-pressed and the sintered pellets.

TABLE VII.4. Leachability Results of Supercalcine Autoclave Tests

\begin{tabular}{|c|c|c|c|c|c|c|c|}
\hline \multirow[b]{2}{*}{ Solution } & \multirow[b]{2}{*}{ Time, $d$} & \multirow{2}{*}{$\begin{array}{c}\text { Leach Rate Based } \\
\text { on Weight Loss, } \\
\mathrm{g} / \mathrm{cm}^{2}-d^{(}(a) \\
\end{array}$} & \multicolumn{4}{|c|}{$\begin{array}{c}\text { Concentration of Element in Solution, } \\
(\% \text { released in parentheses })\end{array}$} & \\
\hline & & & CS & $\mathrm{Rb}$ & Sr & Mo & Sí \\
\hline \multirow[t]{2}{*}{ Brine } & 3 & (c) & 2210 & 487 & 52.5 & 40 & 49 \\
\hline & & & $(46)$ & $(80)$ & $(3.3)$ & $(0.6)$ & $(0.5)$ \\
\hline \multirow[t]{2}{*}{ Brine } & 21 & (c) & 5700 & 1200 & 59 & 7.7 & 31 \\
\hline & & & $(54)$ & (89) & $(1.7)$ & $(0.1)$ & $(0.2)$ \\
\hline Deionized & 21 & $6.2 \times 10^{-4}$ & 20 & 11 & 4.8 & 34 & 25 \\
\hline Water & & & $(0.3)$ & $(1.3)$ & $(0.2)$ & $(0.4)$ & $(0.2)$ \\
\hline
\end{tabular}

(a) Weight loss of a cylinder of material divided by its geometric surface area and time.

(b) Each test included roughly $20 \%$ by weight of a solid cylinder and $80 \%-325$ mesh powder. The majority of ions in solution were leached from the powder.

(c) Not available. 
BRINE
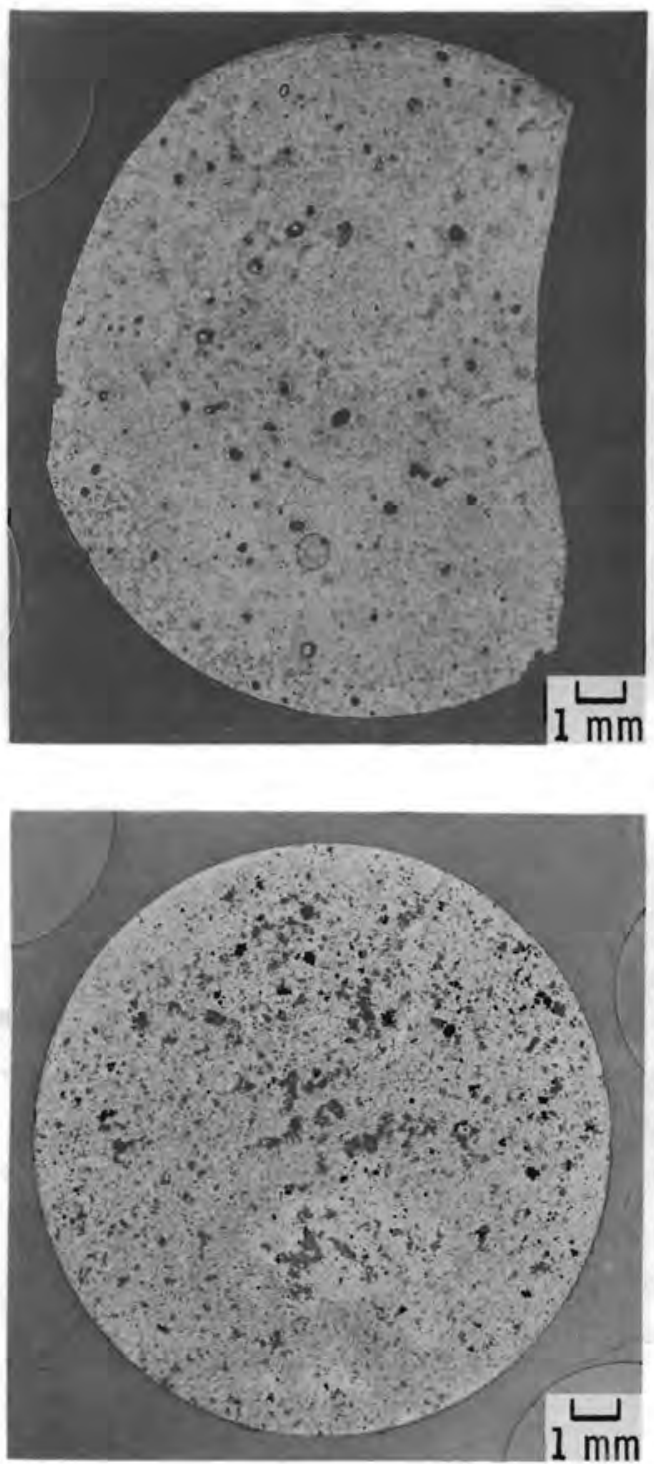

DEIONIZED WATER

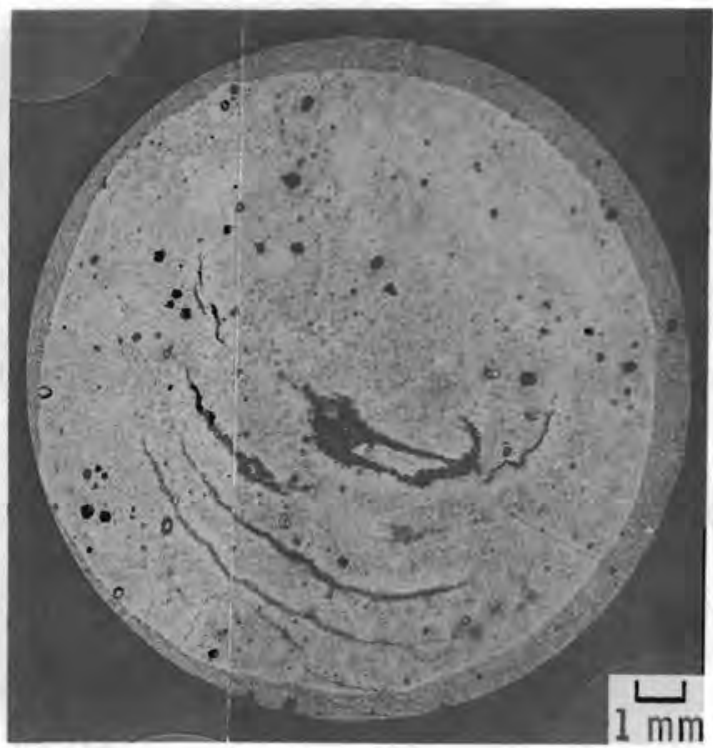

SINTERED

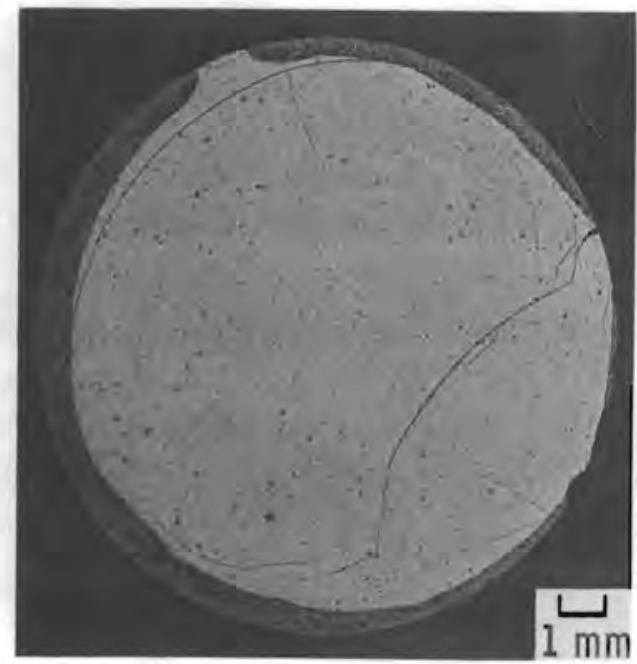

HOT-PRESSED

FIGURE VII.7. Cross Sections of Hot-Pressed and Sintered Supercalcine Pellets Exposed to Hydrothermal Conditions

\section{Oak Ridge National Laboratory Cermet}

The chemical durability of the Oak Ridge National Laboratory (ORNL) Cermet waste form was evaluated using the Soxhlet, $\mathrm{pH}-4, \mathrm{pH}-9$, IAEA, and autoclave leach tests. The thick discs were doped with ${ }^{137} \mathrm{CS}$ and ${ }^{106} \mathrm{Ru}$ at ORNL. Leach rates were then determined using these isotopes and weight loss measurements. The results are shown in Table VII.5.

The Cermet is defined as a continuous iron-nickel metal phase containing small particles of waste oxides (Aaron et al. 1978). In preparing the Cermet, many of the fission products, including ruthenium, are reduced to their metallic states. Cesium is incorporated in a 
TABLE VII.5. Results of Leach Tests on ORNL Cermet

\begin{tabular}{|c|c|c|c|c|}
\hline \multirow[b]{2}{*}{ Leach Test } & \multirow[b]{2}{*}{ Conditions } & \multirow[b]{2}{*}{ Weight Loss } & \multicolumn{2}{|c|}{$\begin{array}{c}\text { Leach Rate, } \\
\mathrm{g} / \mathrm{cm}^{2}-\mathrm{d}\end{array}$} \\
\hline & & & $137 \mathrm{Cs}$ & $107 \mathrm{Ru}$ \\
\hline Soxhlet & $\begin{array}{l}99^{\circ} \mathrm{C}, 72 \mathrm{~h} ; \\
\text { Distilled } \mathrm{H}_{2} \mathrm{O}\end{array}$ & $7.1 \times 10^{-6}$ & $7.2 \times 10^{-5}$ & (a) \\
\hline $\mathrm{pH}-4$ & $\begin{array}{l}25^{\circ} \mathrm{C}, 31 \mathrm{~h} ; \\
\text { Acetate Buffer }\end{array}$ & $7.4 \times 10^{-4}$ & $4.6 \times 10^{-4}$ & $1.0 \times 10-5$ \\
\hline pH-9 & $\begin{array}{l}25^{\circ} \mathrm{C}, 31 \mathrm{~h} ; \\
\text { Ammonium Hydrox- } \\
\text { ide Buffer }\end{array}$ & $1.6 \times 10^{-5}$ & $2.4 \times 10^{-4}$ & $1.7 \times 10^{-6}$ \\
\hline IAEA & $\begin{array}{l}25^{\circ} \mathrm{C}, 146 \mathrm{~d} ; \\
\text { Deionized } \mathrm{H}_{2} \mathrm{O}\end{array}$ & $4.1 \times 10^{-6}$ & $\begin{array}{l}4.3 \times 10^{-6} \\
\text { (average } \\
\text { over } 146 \mathrm{~d} \text { ) }\end{array}$ & (a) \\
\hline Autocl ave & $\begin{array}{l}350^{\circ} \mathrm{C} 7 \mathrm{~d} ; \\
\text { Deionized } \mathrm{H}_{2} \mathrm{O}\end{array}$ & $1.5 \times 10^{-5}$ & $1.5 \times 10^{-2}$ & (a) \\
\hline Autoclave & $\begin{array}{l}350^{\circ} \mathrm{C} 7 \mathrm{~d} ; \\
\text { Sat urated } \mathrm{NaCl}\end{array}$ & $\begin{array}{l}\text { Gained } \\
\text { Weight }\end{array}$ & $3.9 \times 10^{-2}$ & (a) \\
\hline
\end{tabular}

(a) Not detected.

pollucite phase within the metal matrix. The discs we received for leach-testing had mirror surfaces with some slight imperfections--apparently from the waste oxides. Those discs leached at room temperature retained their shiny surfaces after the test. There was a galvanic reaction between the Cermet and the stainless steel baskets used to hold the sample in the pH-4, pH-9, and IAEA leach tests. Rust-colored patches on both the samples and the baskets resulted from this galvanic reaction. Oak Ridge is looking at these samples to determine the changes in the Cermet. The two samples exposed to hydrothermal conditions in a Hastelloy autoclave had dull gray surfaces at the end of the test, but they did not show any rust coloring. The gray finish is probably a thin oxide coating.

The leach rate data do not show any surprises. Ruthenium is less mobile than is cesium and, as such, is not detected in most of the tests. Cesium releases increased with increasing temperature--from $4 \times 10^{-6}$ at $25^{\circ} \mathrm{C}$ to $7 \times 10^{-5}$ at $99^{\circ} \mathrm{C}$ to $1.5 \times 10^{-2} \mathrm{~g} / \mathrm{cm}^{2}-\mathrm{d}$ at $350^{\circ} \mathrm{C}$. This corresponds to an activation energy of $1 \mathrm{kcal} / \mathrm{mole}$. Releases of cesium at a given temperature increase as the ionic strength of the solution increases. The pH-4 and pH-9 test results, when compared with the IAEA test and the two autoclave test results, support this conclusion. Because of the galvanic reaction and the oxide film formation, the leach rates based on weight loss probably do not reveal much about the leaching behavior of the Cermet.

\section{SPENT FUEL}

Spent LWR fuels have been leach-tested to determine the effects of time and burnup on the chemical durability of the fuel. This work originated in the Waste Fixation Program in 1975, 
but is now being funded by the WISAP as part of their spent fuel studies. This work is reported in detail in PNL-2982 (Katayama 1979).

Spent LWR fuels with burnups of 9.0, 28.0 and $54.5 \mathrm{MWd} / \mathrm{kgU}$ have been leach-tested in deionized water at $25^{\circ} \mathrm{C}$ in the Paige leach test apparatus (Mendel et al. 1977). Burnup has no effect upon the leach rates based on ${ }^{137} \mathrm{Cs}$ and $239 \& 240_{\mathrm{Pu}}$ releases, as shown by Figures VII.8 and VII.9. The leach rates based on uranium do appear to be influenced by the burnup of the fuel, as is seen in Figure VII.10. Differences in the physical structure of the fuels may have caused the differences. Light optical examination showed that the low-burnup fuel had less porosity than did the higher-burnup fuels. This is a function of the fabrication and irradiation history of the fuel.

Figure VII.11 shows the leach rate curves based on ${ }^{244} \mathrm{Cm}$. The low-burnup fuel $(9.0 \mathrm{MWd} /$ $\mathrm{kgU})$ has a leach rate approximately 50 times greater than does the high-burnup fuel (54.5 MWd/ $\mathrm{kgU})$. These leach rates are in the reverse order of the curium concentration in the fuel predicted by ORIGEN (Bell 1973), where 54.5-MWd/kgU fuel contains 1000 times the curium concentration of $9.0-\mathrm{MWd} / \mathrm{kgU}$ fuel. After $350 \mathrm{~d}$ of cumulative leaching, the curves for the three different fuels converge and are within the one-order-of-magnitude experimental uncertainty range. The large differences in ${ }^{244} \mathrm{Cm}$ leach rate are short-term when measured on a waste isolation time scale (thousands of years).

A long-term leach effect has been observed with the 54.5-MWd/kgU-burnup spent fue 1 exposed to deionized water at $25^{\circ} \mathrm{C}$. A rise in the leach rates was observed after approximately $600 \mathrm{~d}$ of cumulative leaching, and it is shown in Figure VII.12. During the rise, the leach rates for all the measured radionuclides become nearly equal. Evidence suggests that exposure of new surfaces to the leachant may cause the increase. As a result, a study of spent fuel leaching mechanisms has been initiated. 


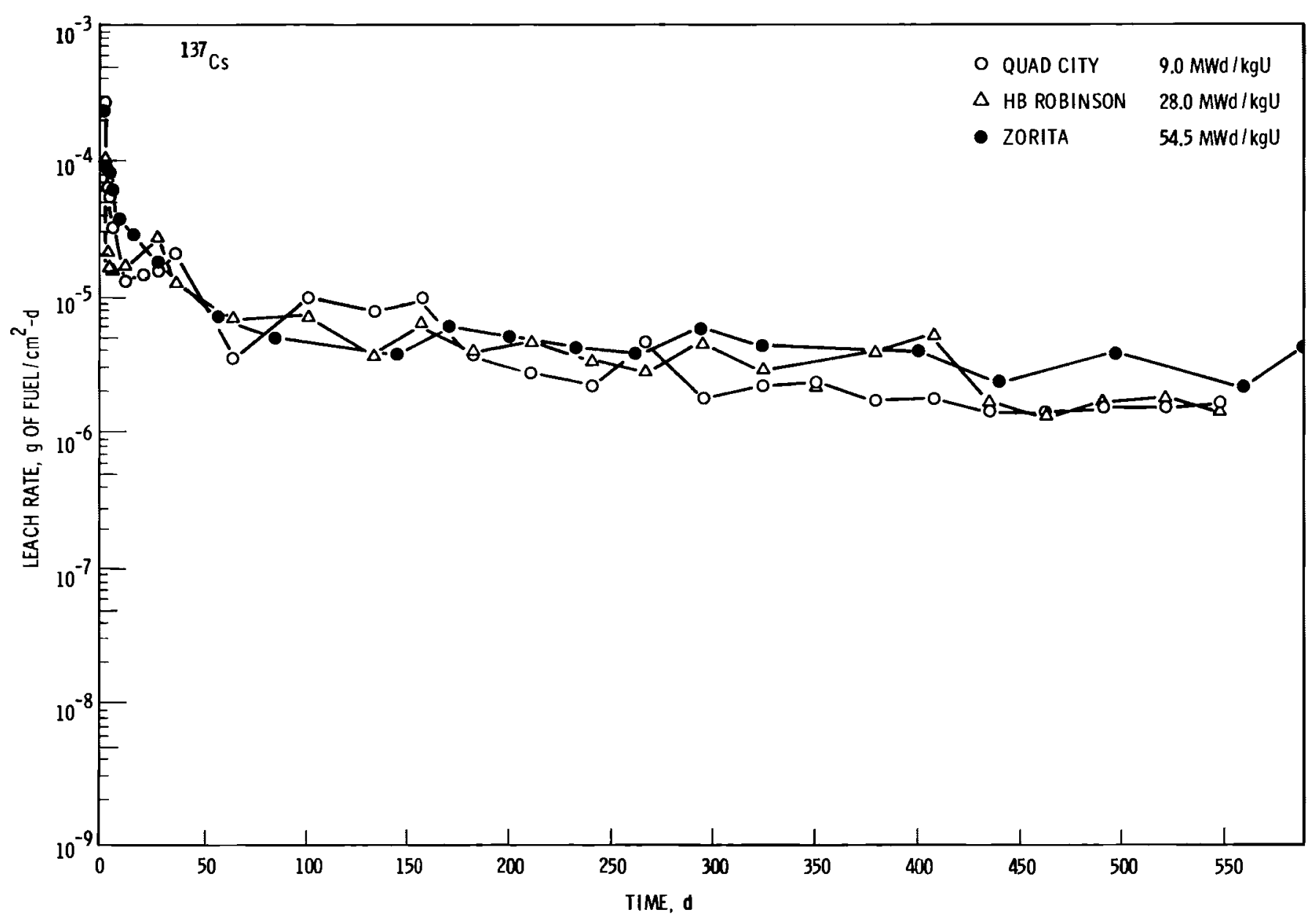

FIGURE VII.8. Leach Rate of Spent Fuels Based on Release of $137 \mathrm{Cs}$ in Deionized Water at $25^{\circ} \mathrm{C}$ with Burnups of $9.0,28.0$ and $54.5 \mathrm{MWd} / \mathrm{kgU}$ 


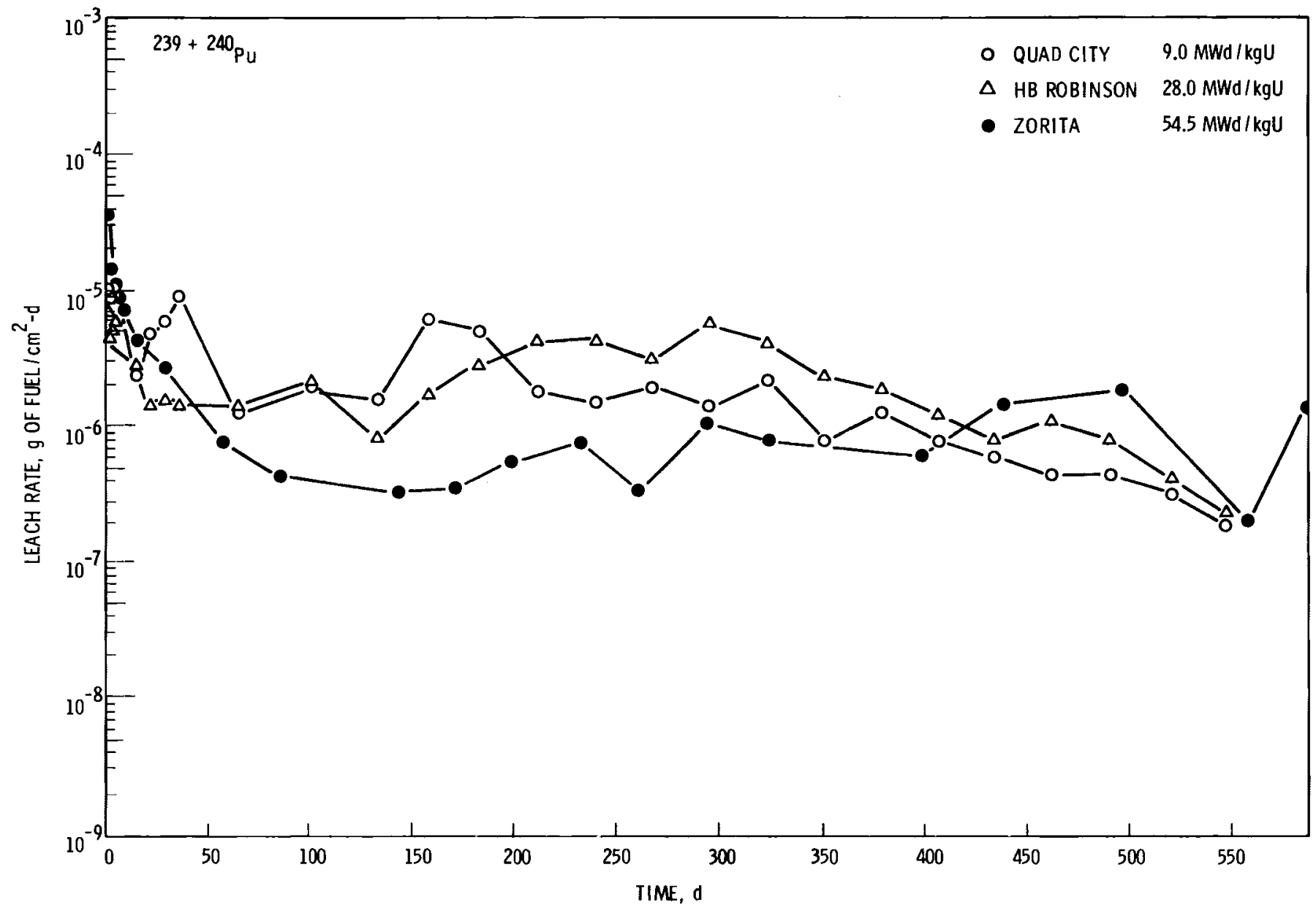

FIGURE VII.9. Leach Rate of Spent Fue 1s Based on Release of 239 \& $240 \mathrm{pu}$ in Deionized Water at $25{ }^{\circ} \mathrm{C}$ with Burnups of $9.0,28.0$ and $54.5 \mathrm{MWd} / \mathrm{kgU}$ 


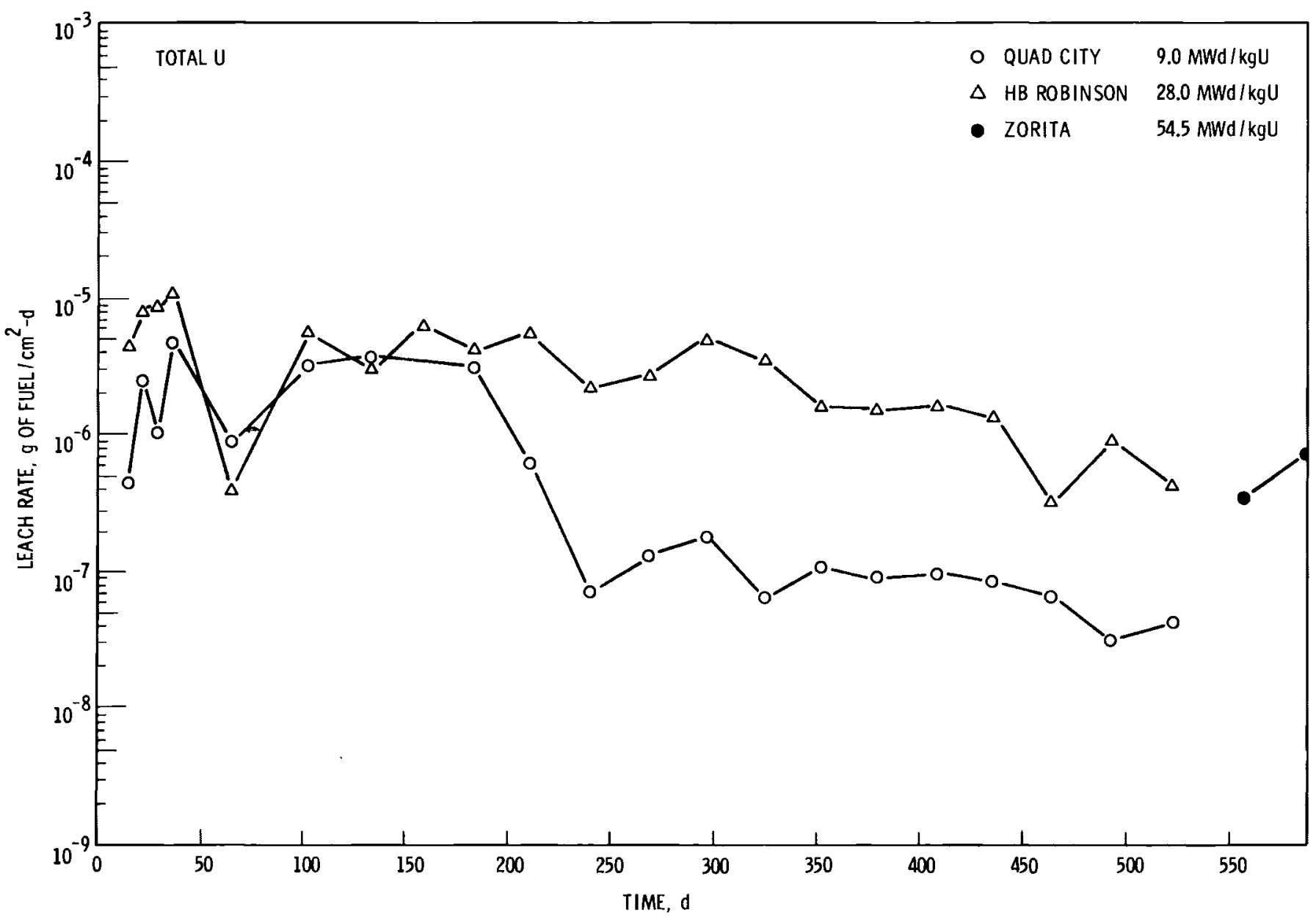

FIGURE VII.10. Leach Rate of Spent Fuels Based on the Release of Uranium in Deionized Water at $25^{\circ} \mathrm{C}$ 


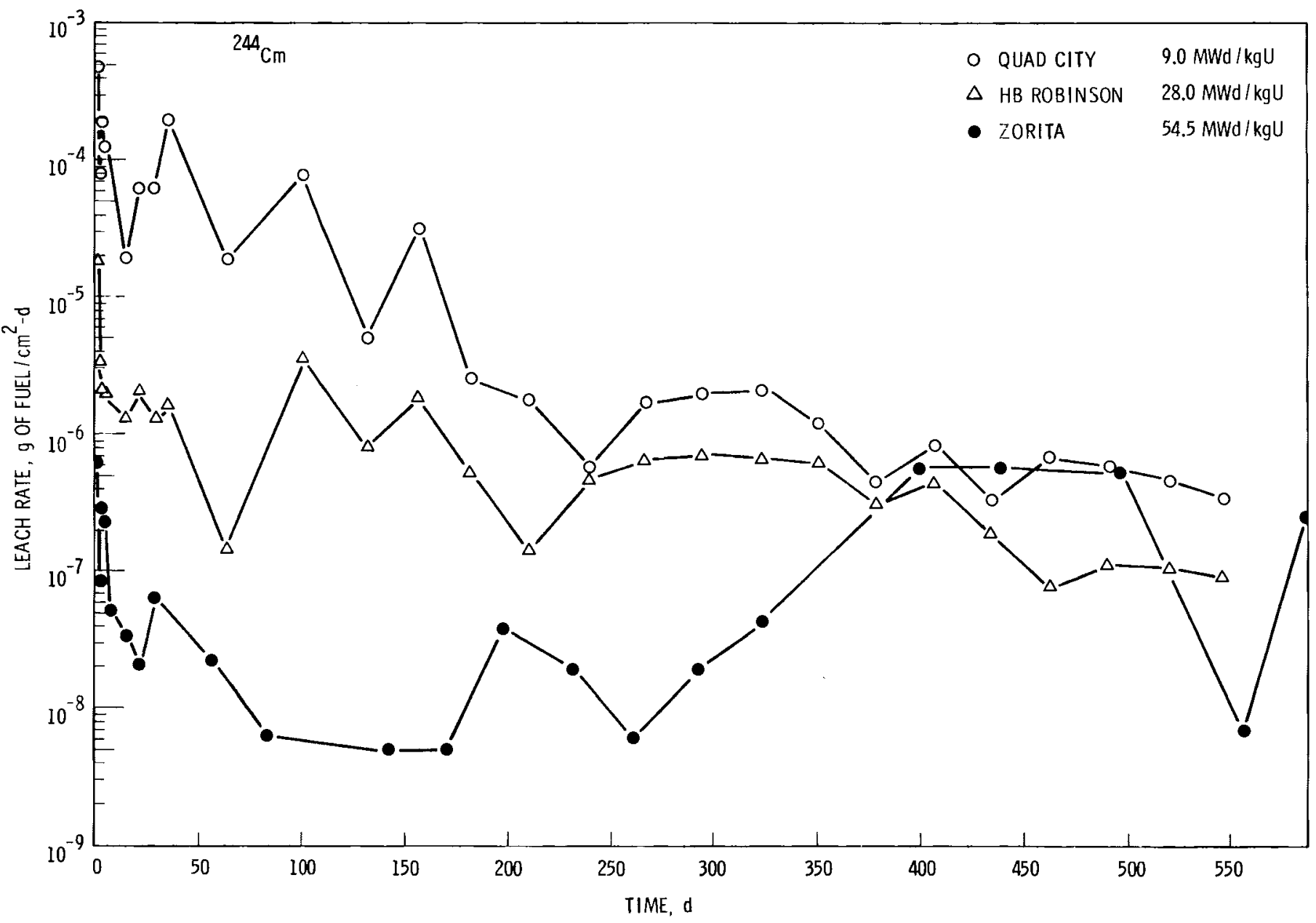

FIGURE VII.11. Leach Rate of Spent LWR Fue ls Based on the Release of ${ }^{244} \mathrm{Cm}$ in Deionized Water at $25^{\circ} \mathrm{C}$ with Burnups of $9.0,28.0$ and $54.5 \mathrm{MWd} / \mathrm{kgU}$ 


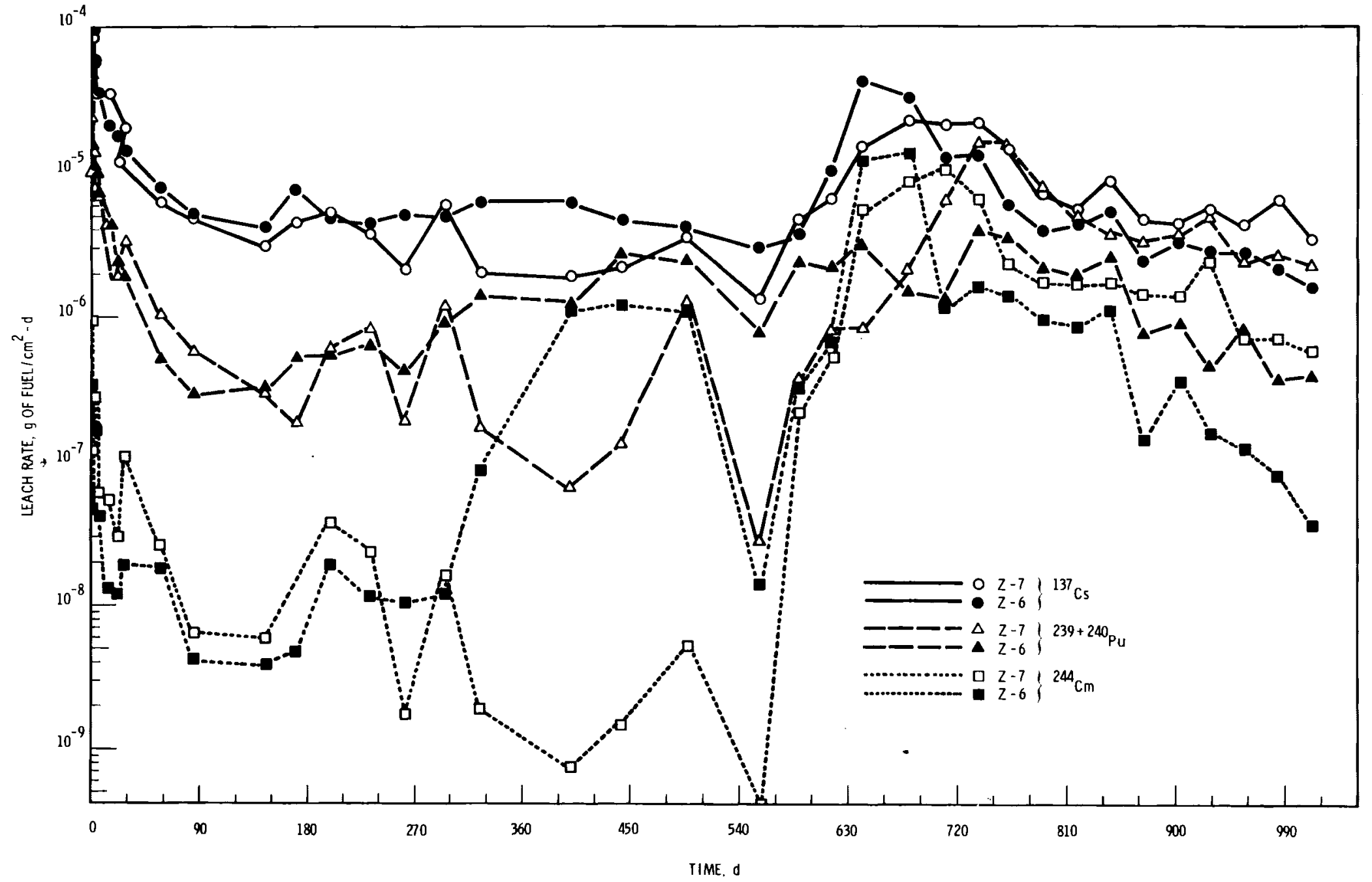

FIGURE VII.12. Leach Rate of 54.5-MWd/kgU Spent LWR Fuel in Deionized Water at $25^{\circ} \mathrm{C}(\mathrm{a})$

(a) Duplicate Samples are Designated Z-6 and Z-7. 
VIII. PHASE BEHAVIOR AND THERMAL EFFECTS

R. P. Turcotte, J. W. Wald and R. P. May

The development of nuclear waste solids requires evaluation of the product with respect to general physical integrity and the composition and concentration of phases present. Clearly, major properties such as stability to alpha-recoil damage or elemental chemical durability cannot be understood without knowing some details of the microstructure within the waste form.

Solid-state analytical work is routinely undertaken as part of most studies reported in other sections of this report. More detailed examination of thermal effects for both glasses and crystalline forms are directed toward optimizing preparation conditions, evaluating longterm self-heating effects, and defining effects in possible accident scenarios. The materials are usually evaluated over broad ranges of time (hours to years) and temperature $\left(25^{\circ}\right.$ to $1400^{\circ} \mathrm{C}$ ), both with respect to vaporization losses and to changes in the solid state. Although waste solids are very complex, most of the usual structural and element-sensitive analytical tools available have been utilized successfully. Methods include x-ray diffraction, optical and electron microscopy, bulk x-ray fluorescence analysis and electron microprobe analysis. other specialized techniques such as alpha-radiography, Auger elemental depth profiling and transmission electron microscopy are also used in some work.

At the present time much more property information is available for nuclear waste glasses than for crystalline nuclear waste forms; this is due in part to the difficulty of analyzing micron-size crystallites in ceramics such as supercalcines. It is nevertheless known that crystalline waste forms offer more thermal/phase stability than do glasses--both with respect to vaporization losses and to changes in microstructure. On the other hand, volatility losses for glasses are also very small, and thermally induced changes (devitrification) can be avoided or controlled. A glass-ceramic waste form, as proposed by workers in Germany, can be produced by the controlled devitrification of specially formulated glasses (Lutze 1979).

The following paragraphs review some of the major features of work during the past year. Further studies will continue to provide volatility-loss comparisons between glasses and crystalline composites. For crystalline waste forms, much more information on phase concentration/ compositions is needed, as are time-dependence studies of high-temperature changes. With respect to glass devitrification, work will be broadened to cover the large composition field being evaluated in glass development studies.

\section{VOLATILITY}

Volatility studies in our work rely upon thermogravimetric methods with "cold finger" collection of vaporized species (for subsequent chemical analyses). Some results have already been reported by Gray (1976). For waste glasses and for supercalcines, vaporization appears to follow an Arrhenius temperature dependence with activation energies such that volatility at $1100^{\circ} \mathrm{C}$ decreases a factor of $10^{5}$ or more at $\sim 600^{\circ} \mathrm{C}$. As expected, the alkali elements are major contributors--especially important because $C_{S}$ is a major biohazard for the first few hundred years. 
Results for Cs are summarized in Figure VIII.l for several glasses, for a Purex-type calcine composition ( $\mathrm{PW}-4 \mathrm{~b}$ ), and for several hot-pressed supercalcine formulations. Also, some single-point data are shown for $\mathrm{CSAlSi}_{2} \mathrm{O}_{6}$ and $\mathrm{CsAlSiO}_{4}$. It is important to recognize that the fractional losses reflect the sample size and geometry used in the experiments. A fractional loss of $10^{-2}$ after $4 \mathrm{~h}$ in this work relates only to a sample depth of $\sim 1 \mathrm{~cm}$. Volatility from the top of a large canister, for example, would be orders of magnitude smaller in terms of fraction lost. In a comparative sense, the results clearly show crystalline forms have volatility losses 10 to 100 times lower than do typical waste glasses. For glasses, the presence of water has a small effect, and addition of alumina reduces Cs volatility--probably by simple increase of the viscosity. It is noteworthy that unconsolidated calcine PW-4b shows high losses at $800^{\circ} \mathrm{C}$. For both glasses and supercalcines, projected volatility losses at low temperatures (e.g., $500^{\circ} \mathrm{C}$ ) are negligible.

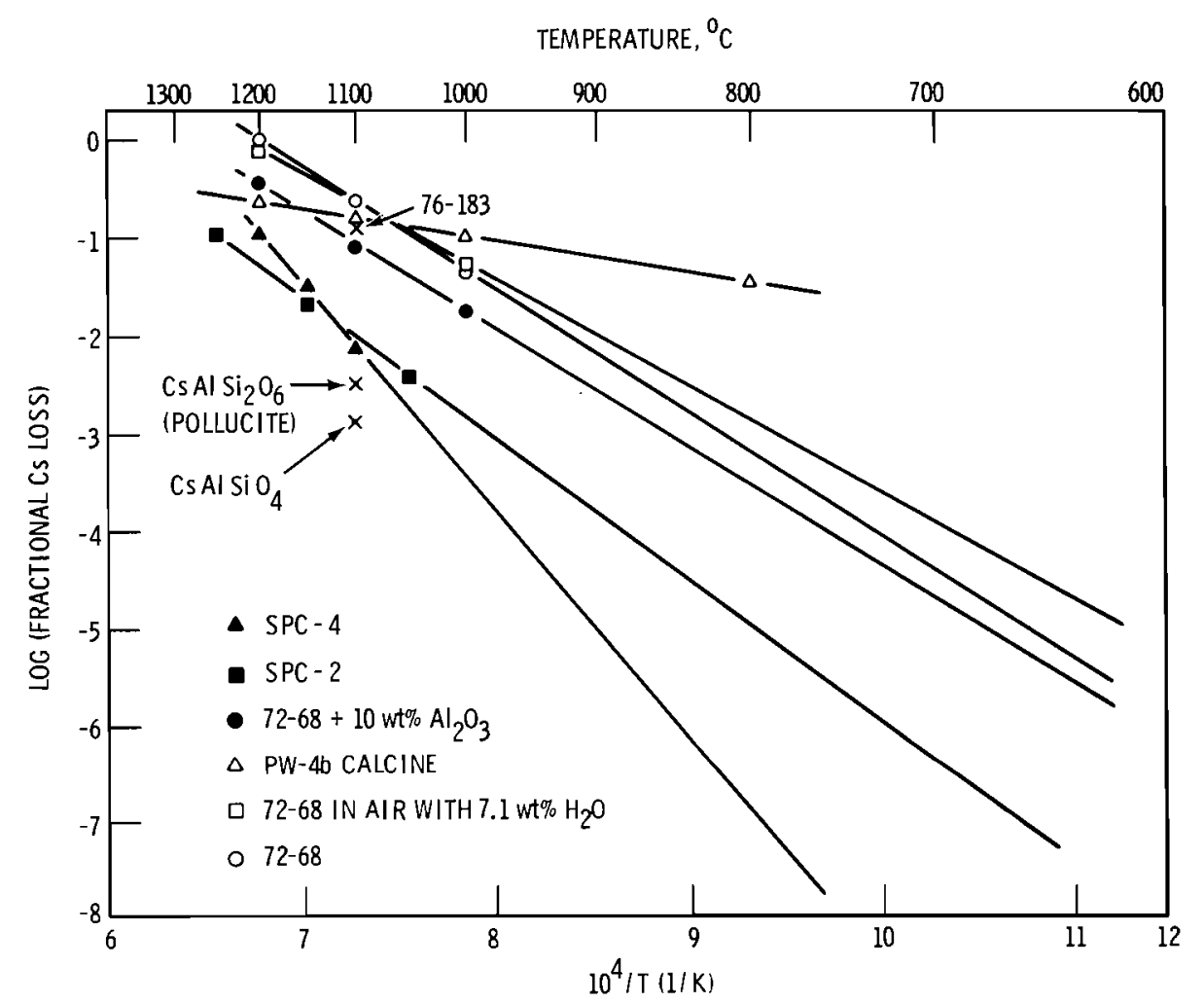

FIGURE VIII.1 Fraction of Cesium Lost after $4 \mathrm{~h}$ at Respective Temperatures from a Thin $(\sim 1-\mathrm{cm})$ Sample of Material 


\section{GLASS DEVITRIFICATION}

Detailed devitrification studies have been made on eight glass compositions using isothermal and constant cooling rate methods. Details on glass 72-68 have been reported earlier (Turcotte and Wald 1978). More recent work on four glass compositions prepared with actual high-level waste (HLW) calcine shows that simulated glasses do show the same behavior seen in actual HLW glasses (Wald and Westsik 1979). The work on simulated and HLW glasses continues to suggest that devitrification has a relatively small effect upon mechanical and chemical durability. It also indicates that radioactivity does not affect the types of crystal phases formed.

Figure VIII.2 shows "percent-crystallinity" curves as a function of temperature for three glass compositions after annealing periods of $1 \mathrm{~d}$ and $60 \mathrm{~d}$, as estimated by x-ray diffraction. Table VIII.1 lists the phases present in each of the glasses. The least stable glass (77-260) shows a bimodal crystallinity envelope arising from rapid formation of a gadolinium titanate phase at high temperatures, whereas formation of a rare-earth apatite phase becomes important at longer times and lower temperatures--being the major contributor to a $45 \%$ crystalline content after $60 \mathrm{~d}$ at $600^{\circ} \mathrm{C}$. Composition 76-68, which contains high iron and sodium concentrations, is nevertheless the most devitrification-resistant glass studied--both with respect to crystal yield and to the temperature region over which significant changes occur $\left(600^{\circ}\right.$ to $800^{\circ} \mathrm{C}$ ). However, it too becomes extensively crystallized after annealing at $650^{\circ} \mathrm{C}$ for one year, with a slow-forming silicate $\left(\mathrm{NaFeSi}_{2}{ }_{6}\right)$ becoming the predominate phase. Figure VIII.3 illustrates the devitrification kinetics in the form of time-temperature-transformation ( $t t t$ ) curves for a $5 \%$ crystal yield for two of the glasses. Most of the data available for other glass compositions falls near or within the region bounded by the two curves given. It should be noted that the curves are overall representations of rather complex processes, since two to three major phases are crystallizing with different time-temperature kinetics--each with its own liquidus temperature. The relatively narrow band describing crystallization kinetics is a direct result of a glass development criterion that viscosity should be 2200 poise or less at $1050^{\circ} \mathrm{C}$. Hence, most waste glass compositions studied to date have similar ion mobilities in the melt, giving rise to relatively narrow property ranges. If the curve for glass 76-68 is examined, it is clear that $\sim 5 \%$ crystalline yield is achieved in one day (or slightly less) at between $700^{\circ}$ and $800^{\circ} \mathrm{C}$. At $650^{\circ} \mathrm{C}, 10 \mathrm{~d}$ are required, and at $590^{\circ} \mathrm{C}$ one year is needed. At $875^{\circ} \mathrm{C}$, 5\% devitrification is not achieved even though the kinetics are rapid, because the glass is near the liquidus temperature $\left(\sim 900^{\circ} \mathrm{C}\right)$.

The effect of devitrification on leach rate is minimal, as is reported in Section VII. With respect to physical integrity, formation of large crystals has been observed to cause microcracking, which can, however, be entirely avoided by maintaining temperatures at not more than $\sim 100^{\circ} \mathrm{C}$ above the dilatometric softening point. For present waste glasses, long-time annealing at temperatures between $500^{\circ}$ to $650^{\circ} \mathrm{C}$ results in a fine dispersion of micronsized crystals similar to glass-ceramic textures. No crystallization has been observed below $500^{\circ} \mathrm{C}$. 


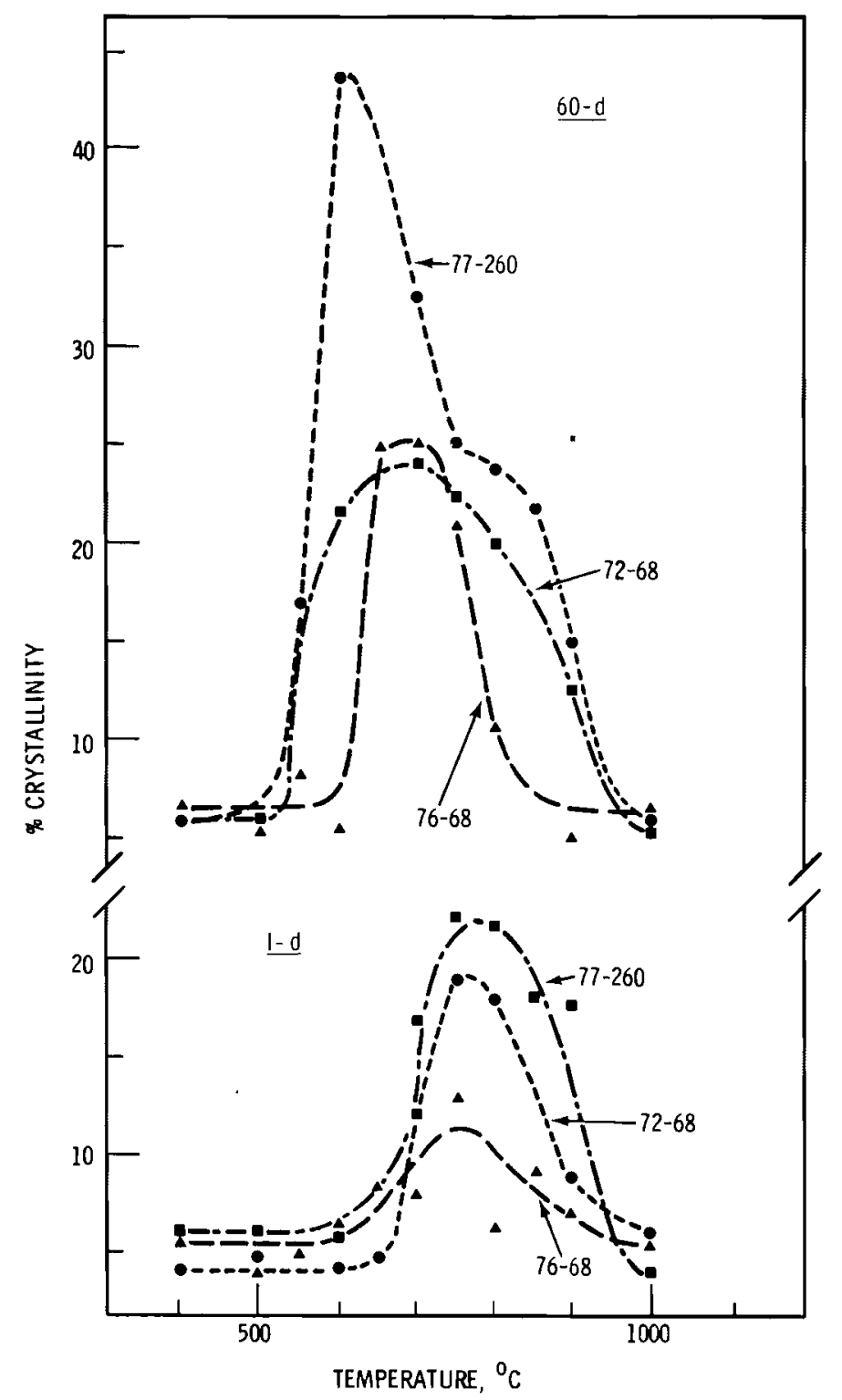

FIGURE VIII.2. Percent-Crystallinity Curves as a Function of Temperature for 1-d and 60-d Anneals 
TABLE VIII.1. Principal Crystalline Phases Observed in Devitrified Waste Glasses $72-68,76-68$ and 77-260

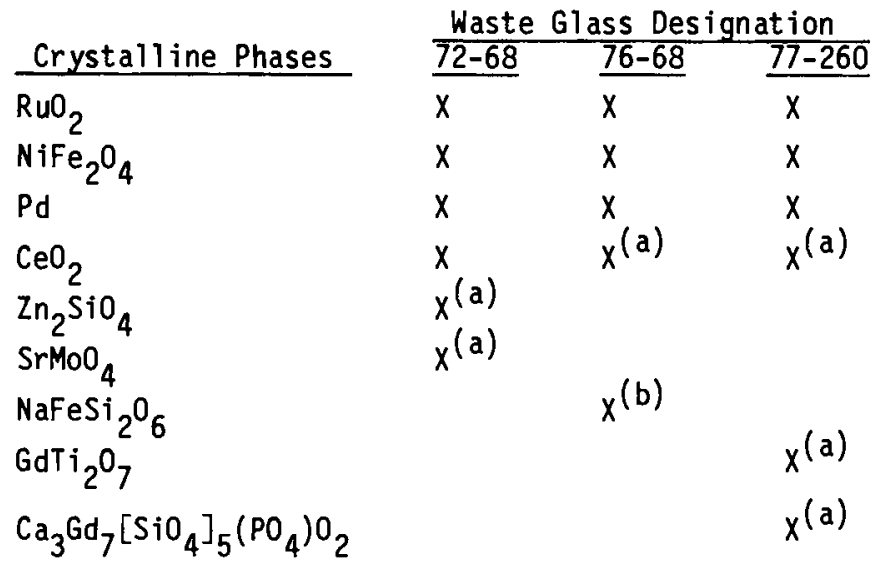

(a) Devitrification product.

(b) Appears only after a one-month anneal.

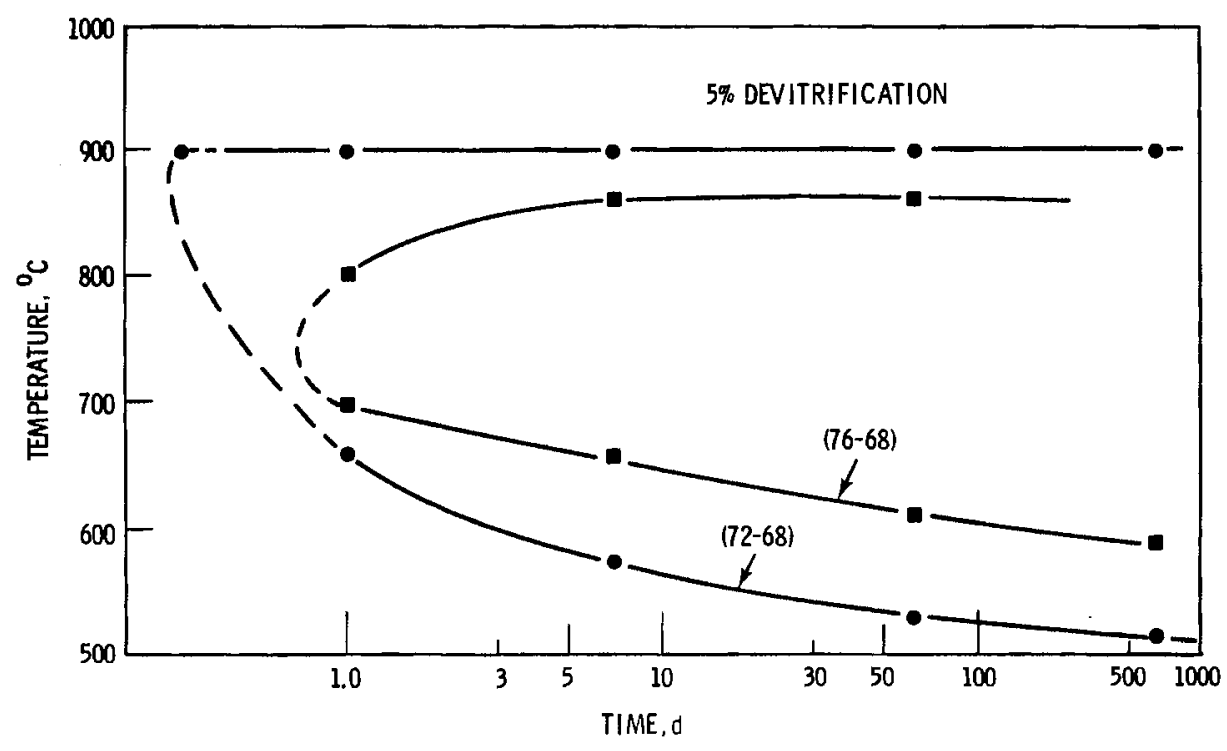

FIGURE VIII.3. Time-Temperature Transformation (5\%) Curves for Waste Glasses 72-68 and 76-68 


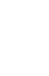

. 


\section{RADIATION EFFECTS}

R. P. Turcotte, W. E. Weber, J. W. Wald and F. P. Roberts

The effects resulting from radioactive decay processes occurring in nuclear waste solids have been under continuing study, and previous findings were reported in past annual reports (Mendel et a1. 1977; Ross et al. 1978). The current studies include work on a variety of glass compositions, a glass-ceramic, and a predominately crystalline ceramic (supercalcine). Although most of the work has concentrated on use of ${ }^{244} \mathrm{Cm}$ to accelerate alpha-decay damage, some $i$ on bombardment work is also in progress (conducted by W. Primak, Argonne National Laboratory), as are literature reviews and experimental studies related to metamict minerals (conducted by R. Ewing and R. Haaker, University of New Mexico). Studies are also progressing toward evaluating the importance of transmutation (the specific reaction chosen for study is $C s+B a)$ on properties of several glass and crystalline compositions.

The work covered in the following sections shows that radiation-induced changes are not as great in glasses as in crystalline materials. Since high-energy particles induce randomness, crystals are often subject to amorphization, with corresponding large volume changes ( 1 to $15 \%)$. Although theoretical understanding of radiation damage in glass and ceramic materials is not well developed, the damage caused by decay of the actinides can be estimated to saturate at near $10^{19}$ alpha-events $/ \mathrm{cm}^{3}$ in homogeneous solids (Weber et al. 1979). In studies of waste solids, saturation effects are actually observed at doses below this estimate--often in the range 2 to $5 \times 10^{18}$ alpha-events $/ \mathrm{cm}^{3}$. Doses at this level will be reached even in relatively low-activity defense wastes. Although we have demonstrated that no significant change in leach rate occurs in glasses and partially crystallized glasses due to alpha-decay (Weber et al. 1979), additional work is needed on new glass compositions, as well as on crystalline solids.

\section{GLASSES}

Glass studies have now shown that saturation of radiation effects does occur and that there is no important physical or chemical degradation, provided the actinides are homogeneously incorporated. Figure IX.1 shows the volumetric changes measured in several glasses, a glass-

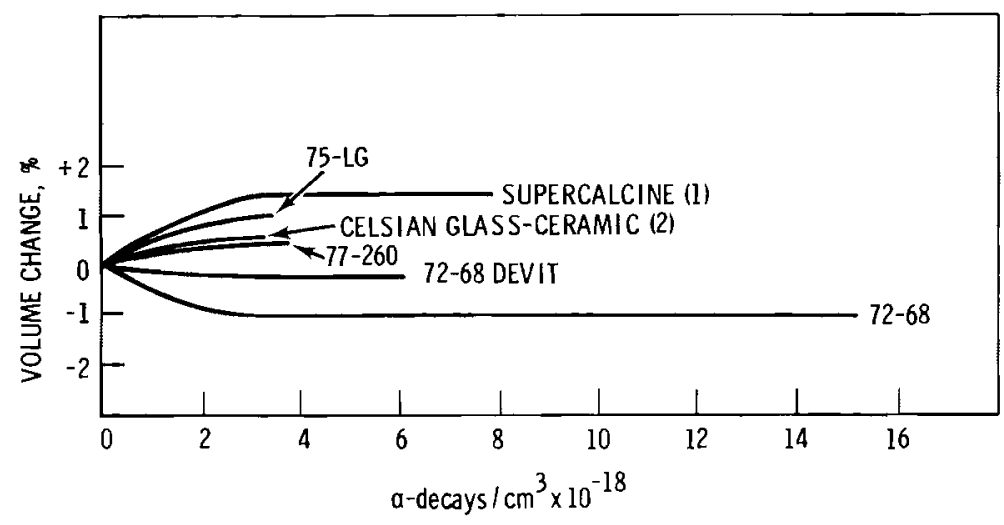

FIGURE IX.1. Change in Density of Waste Materials as a Function of Alpha-Radiation Dose 
ceramic and a supercalcine; these changes are small in all cases, and can be near zero for glasses, depending upon the composition. There is a possibility that physical integrity may not be retained if the actinides are inhomogeneously concentrated at certain locations in the glass, because of glass-glass phase separation or through formation of insoluble oxides or devitrification products. Such segregations may lead to inhomogeneous volumetric changes not easily accommodated in brittle materials. Several experiments have been completed which, in fact, demonstrate that devitrified glasses with large crystal size $(210 \mu \mathrm{m})$ can be microfractured by nonhomogeneous radiation damage. Even in dilute concentration (i.e., $\sim 0.05 \mathrm{wt} \%$ ) the actinides readily crystallize, and also directly follow glass-glass phase separation if it occurs.

To examine the behavior of dilute concentrations of actinides, three glass compositions (77-260, 77-107, and SRP-1) were doped with actinides at levels as follows (in wt\%): ${ }^{237} \mathrm{~Np}(0.25),{ }^{239} \mathrm{Pu}(0.04),{ }^{243} \mathrm{Am}(0.04),{ }^{244} \mathrm{Cm}(0.015)$. Glasses were prepared by adding nitric/HF acid solutions of the individual actinides to the powdered simulated waste glass and then melting at $1050^{\circ} \mathrm{C}$ for 4 hours. Heat-treatment followed, with 96-h anneals being done at $950^{\circ} \mathrm{C}$ or $850^{\circ} \mathrm{C}$. In all cases, a marked tendency to crystallize was observed, generally with $\mathrm{Np}$ and $\mathrm{Pu}$ behaving in a similar fashion (i.e., $\mathrm{M}^{4+}$ ) and $\mathrm{Cm}$ and Am following the same trends (i.e., $\mathrm{M}^{3+}$ ). An alpha-autoradiograph obtained using the cellulose-nitrate method is shown in Figure IX.2 for Am, following treatment at $850^{\circ} \mathrm{C}$ for glass SRP-1. The lowertemperature treatment produces relatively large needle-shaped rare-earth aluminum-silicate crystals, as well as a second phase concentrating near the surface of the melt. Following the $950^{\circ} \mathrm{C}$ treatment, two of the three glasses showed some evidence of macro-scale glass-glass phase separation, with a corresponding inhomogeneous distribution of the actinides. We would postulate that if such actinide phase separation occurred in an actual high-level waste glass, the radiation-induced volume changes would also be inhomogeneous, leading to micro-cracking. Experimentally, strength loss (cracking) has never been observed in any of our radiation damage studies of as-melted $\mathrm{glasses,}$ although there has been one report of radiation-induced cracking by Bibler and Kelley (1978).

We have recently completed a radiation damage study which involved the intentional crystallization of glass. In this work, glass $77-260$ was doped with ${ }^{244} \mathrm{Cm}$ (2 wt\%). Separate portions were heat-treated so that one had a microstructure with a uniform dispersion of small crystals and the other had a coarse distribution of larger crystals. From previous work, we knew that a major devitrification phase in this glass was a rare-earth silicate (apatite), which was susceptible to amorphization. The micrographs given in Figure IX. 3 show the asprepared glass (a), a large crystal sample (b), and a small crystal sample (c). The alpharadiograph ( $d, e)$ shows that the $\mathrm{Cm}$ is highly concentrated in two crystalline phases: a rare-earth silicate and a rare-earth titanate. Even before radiation effects had caused the silicate phase to become fully $x$-ray-amorphous, rather extensive microcracking was observed (Figure IX.3f). Other details of the work, including results of density, stored energy, impact and leaching tests have been reported (Weber et al. 1979). Major conclusions from the study are: 


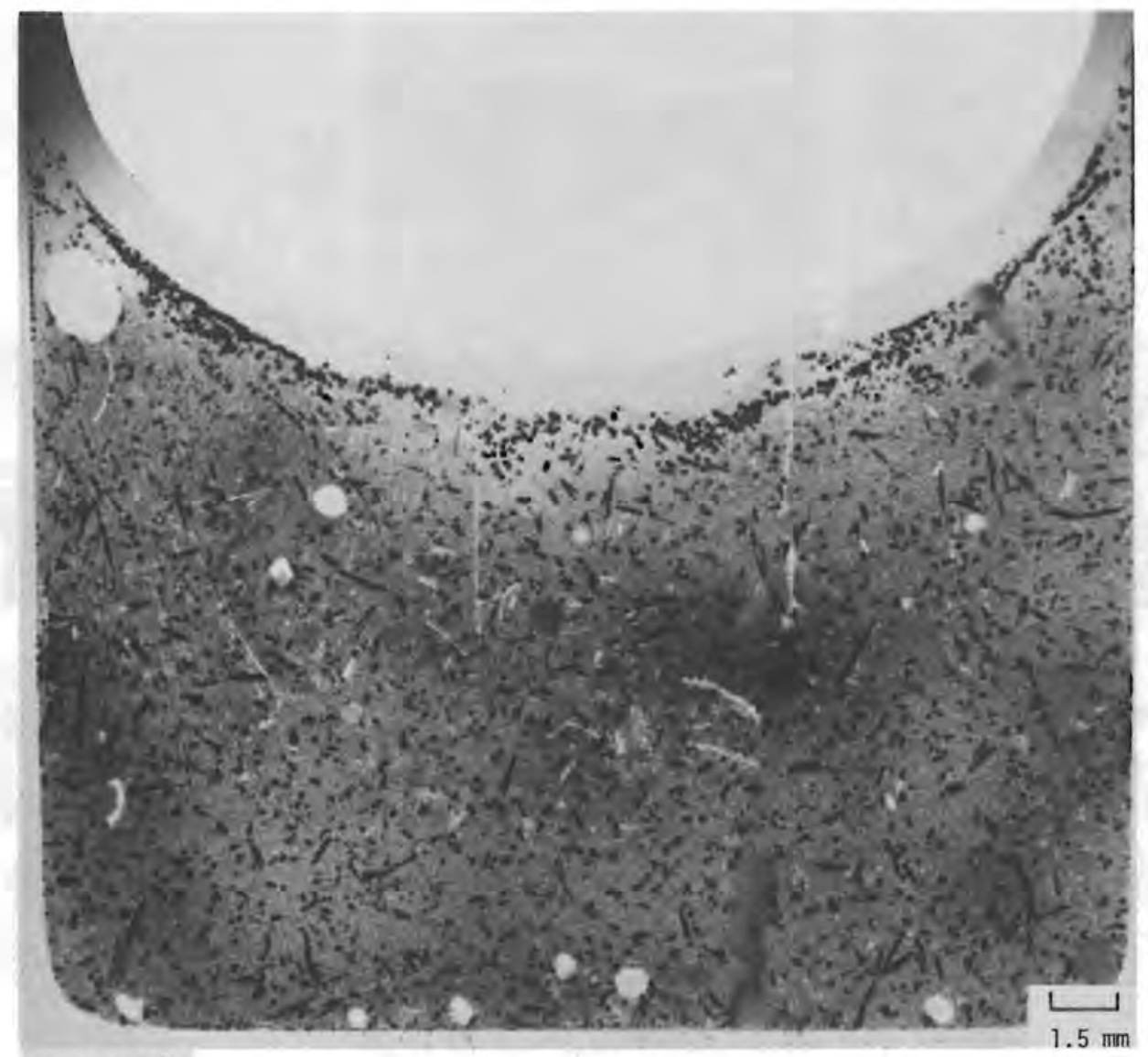

$\operatorname{SRP}-1\left(850^{\circ} \mathrm{C}\right)$

\section{FIGURE IX.2. Alpha-Radiograph Showing Concentration of Am Dopant (0.04 wt\%) in Devitrification Phases}

- Physical/structural changes in the devitrified glasses are greater than those seen in the vitreous form. Nevertheless, radiation-induced changes in density, leachability, impact behavior and stored energy are small in all cases.

- In this study, the gadolinium-titanate phase with a cubic structure was stable to selfradiation. The apatite structure $\left[\mathrm{Ca}_{3} \mathrm{Gd}_{7}\left(\mathrm{SiO}_{4}\right)_{5}\left(\mathrm{PO}_{4}\right) \mathrm{O}_{2}\right]$ was unstable and transformed to an $\mathrm{x}$-ray-amorphous state. There is a relatively large radiation-induced increase in crystal volume, causing microfracturing of the glass matrix. The cracking is minimal if the crystals are small $(<5 \mu \mathrm{m})$.

- For the glass compositions studied, self-radiation does not significantly affect chemical durability or impact performance. Neither the observed crystalline phase amorphization nor the microfracturing cause major changes in the net material leached or in the impact particle size distribution. 

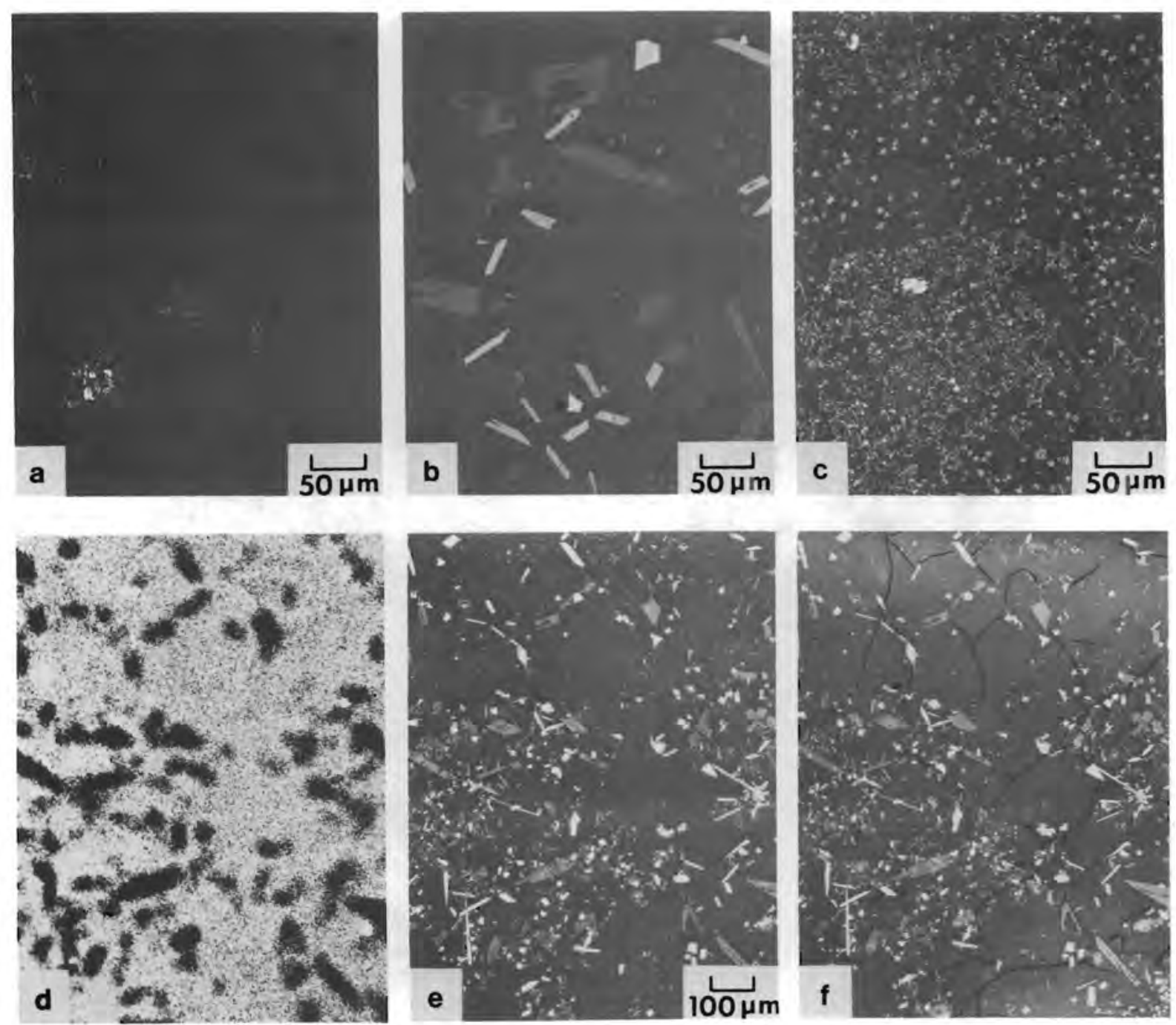

FIGURE IX.3. Initial Microstructures in the Three Waste Giass Forms Investigated and Alpha-Autoradiograph with Corresponding Optical Images Before and After Micro-Fracturing(a)

(a) As-prepared, vitreous sample (a); partially devitrified sample cooled at $-6^{\circ} \mathrm{C} / \mathrm{h}$ (b); partially devitrified sample annealed at $700^{\circ} \mathrm{C}$ for one week (c); alpha-autoradiograph of region shown in (e) and (f), (d); slow-cooled sample $\left(-6^{\circ} \mathrm{C} / \mathrm{h}\right)$ exhibiting no microcracks after $2 \times 10^{16} \alpha$-decays $/ \mathrm{cm}^{3}$ (e); microcracks developed in same area after $8 \times 10^{17} \alpha$-decays $/ \mathrm{cm}^{3}(\mathrm{f})$.

\section{CRYSTALLINE WASTE SOLIDS}

The greatest radiation damage effects observed in glass systems result from the presence of crystalline phases that are susceptible to alpha-recoil damage. Studies are just beginning that will quantify the significance of amorphization of crystalline phases with respect to changes in chemical durability. It has been pointed out by Ewing and Haaker (1979) that in nature, metamict zircon is more highiy altered than are adjacent layers of undamaged zircon, but that the chemical changes are poorly understood. 
To ensure continued physical integrity, it would seem that 1 arge volume changes of any individual phase should be avoided. In the two crystalline waste forms studied so far, neither supercalcine nor a glass-ceramic became visibly degraded (strength tests have not yet been made), even though phases containing curium became $x$-ray-amorphous and exhibited relatively 1 arge volume changes. Figure IX.4 shows volume changes measured for a number of individual phases. All of the compounds shown become $x$-ray-amorphous in relatively short times except for $\mathrm{PuO}_{2}$, which only shows a moderate volume change even after receiving doses much larger than those plotted here. The apatite and titanate curves shown can be compared to the density changes measured for the parent waste form given in Figure IX.1, for supercalcine, and for the glass-ceramic. When this is done, the total waste form volume changes are larger than can be accounted for based simply on amorphization of any single phase. The reason for this is that the actinide-containing phases are point sources of $5 \mathrm{MeV}$ alpha particles, which are capable of damaging adjacent material. Since the crystals are in the micron or submicron range, and since the alpha-particle range is $\sim 20$ microns, all of the phases present are subject to longterm radiation damage.

Although radiation damage in polyphase waste ceramics is a complex process, the net effects do not appear to be of major consequence. Much more work is required, particularly with respect to radiation-induced changes in chemical durability, and in determining effects on large-grain-sized materials.

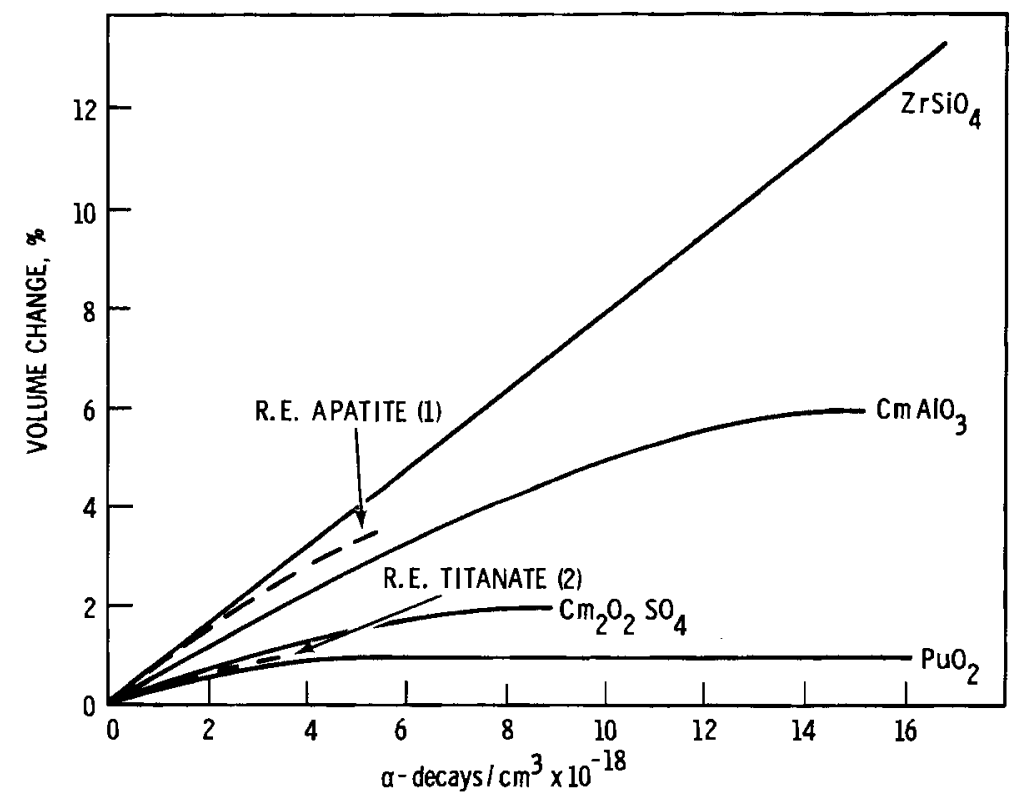

FIGURE IX.4. Volume Changes for Crystalline Phases as a Function of Accumulated $\alpha$-Damage 


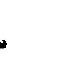

. 


\title{
$X$. THERMAL AND MECHANICAL SHOCK
}

\author{
L. R. Bunne11
}

As part of an effort to characterize the effect of impact on large (up to 0.91-m-dia) canisters filled with simulated Hanford waste glass by the ceramic melter, canisters were first examined in the as-filled condition. Canisters of three different diameters were examined:

$$
\begin{aligned}
& \text { Canister } 32=0.41 \mathrm{~m} \text { in dia } \times 2.74 \mathrm{~m} \text { long; } \\
& \text { Canister } 31=0.61 \mathrm{~m} \text { in dia } \times 2.43 \mathrm{~m} \text { long; } \\
& \text { Canister } 36=0.91 \mathrm{~m} \text { in dia } \times 2.74 \mathrm{~m} \text { long. }
\end{aligned}
$$

The $\mathrm{glass}$ in the canisters was made available for examination by removing full-length, $120^{\circ}$ sectors of the walls using a milling machine. The sections were lifted away and the contents of each canister were examined visually. Canister 32, shown in Figure X.1, is representative. In all cases, the glass immediately adjacent to the canister was severely thermally quenched and had separated into concentric layers 0.16 to $0.64 \mathrm{~cm}$ thick. The glass showed a number of complex flow patterns--a result of the fill rate $(\sim 45 \mathrm{~kg} / \mathrm{h})$ and the quench caused by pouring the glass into a room-temperature canister. Because of the outer-layer cracking, the outer $2.5 \mathrm{~cm}$ was sampled separately. The glass pieces became larger as the core of the canister was approached; pieces nearly $15 \mathrm{~cm}$ in dia were found at the center. Since the larger fragments were locked into place, all sizing data is somewhat biased toward smaller sizes because of the physical force necessary to dislodge the samples.

After the glass was hand-sorted into $+7.6-\mathrm{cm}$ and $-7.6-\mathrm{cm}$ fractions, it was sieved. A shaker, a set of standard sieves and a 1-h shaking time were used. The sieving also generated fines not in the original sample. Table X.1 shows the sieving results to a minimum screen size of $44 \mu \mathrm{m}$. The fraction passing that screen size, including the $-10-\mu \mathrm{m}$ material generally regarded as respirable, was evaluated by a sedimentation technique. (a) The respirable fraction is extremely small $\left(<2.7 \times 10^{-3} \%\right)$ for canister 31 .

Specific surface areas for the glass were calculated by assuming that the particles were spherical. The area was $0.63 \mathrm{~cm}^{2} / \mathrm{g}$ for the $0.41-\mathrm{m} \mathrm{can}, 0.91 \mathrm{~cm}^{2} / \mathrm{g}$ for the $0.61-\mathrm{m} \mathrm{can}$, and $0.56 \mathrm{~cm}^{2} / \mathrm{g}$ for the $0.91-\mathrm{m}$ can. This surface area is a factor of considerable interest, since it can be used to calculate the ratio of surface area, including cracks, to that of an uncracked monolith of the same dimensions. The ratio was 18.1:1 for the 0.41-m can, 27.4:1 for the 0.61-m can, and 33.9:1 for the 0.91-m can. The increasing ratios result from the relative constancy of the specific surface area combined with the lower surface/volume ratio that accompanies an increase in can sizes. The ratio of surface to volume can be related to a radius for a sphere. At a value of $0.63 \mathrm{~cm}^{2} / \mathrm{g}(0.41-\mathrm{m}$ can) the equivalent radius is $1.6 \mathrm{~cm}$, indicating that all of the waste glass in the canister was reduced by cracking to the equivalent of च3-cm-dia spheres.

(a) Sedigraph 5000, Micromeritics Corporation. 


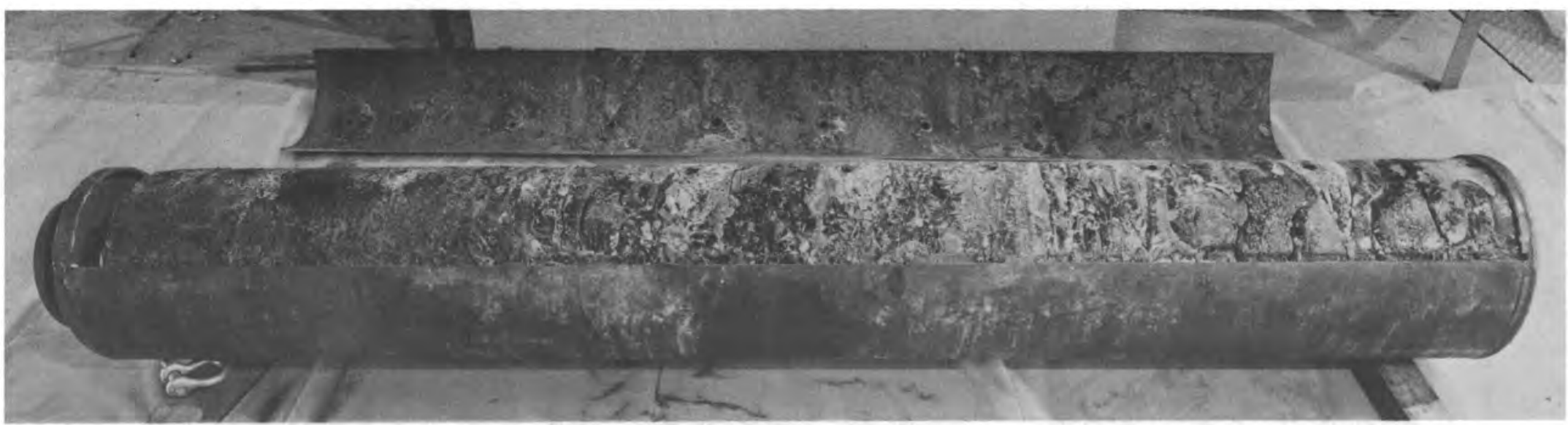

FIGURE X.1. Canister CM-1, with Sector Removed from Side ${ }^{(a)}$

(a) Note flow patterns--most evident near the canister bottom, where glass contacted coldest metal. 
TABLE X.1. Sizing Data $(+44 \mu \mathrm{m})$ for As-Filled Canisters

\begin{tabular}{|c|c|c|c|c|c|c|c|c|c|}
\hline & & & & & Screen 5 & $z e, \operatorname{mm}(a)$ & & & ' \\
\hline Sampling Location & $\underline{150}$ & 72.6 & -25.4 & 2.83 & 0.850 & 0.420 & 0.150 & 0.074 & 0.044 \\
\hline $\begin{array}{l}\# 32 \\
0-30 \mathrm{~cm} \text { from bottom, } \\
0-2.5 \mathrm{~cm} \text { in }\end{array}$ & 100 & 100 & 24.3 & 1.38 & $3.18 \times 10^{-1}$ & $1.63 \times 10^{-1}$ & $5.94 \times 10^{-2}$ & $2.76 \times 10^{-2}$ & $1.27 \times 10^{-2}$ \\
\hline $\begin{array}{l}\# 32 \\
0-30 \mathrm{~cm} \text { from bottom, } \\
2.5 \mathrm{~cm} \text { to center }\end{array}$ & 100 & 69.6 & 9.02 & $6.67 \times 10^{-1}$ & $1.39 \times 10^{-1}$ & $7.97 \times 10^{-2}$ & $2.72 \times 10^{-2}$ & $1.27 \times 10^{-2}$ & $7.30 \times 10^{-3}$ \\
\hline $\begin{array}{l}\# 32 \\
1.2-1.5 \mathrm{~m} \text { from bottom, } \\
0-2.5 \mathrm{~cm} \text { in }\end{array}$ & 100 & 87.1 & 19.0 & $1.64 \times 10^{-1}$ & $4.86 \times 10^{-2}$ & $2.60 \times 10^{-2}$ & $8.22 \times 10^{-3}$ & $2.80 \times 10^{-3}$ & $1.08 \times 10^{-3}$ \\
\hline $\begin{array}{l}\# 32 \\
1.2-1.5 \mathrm{~m} \text { from bottom, } \\
2.5 \mathrm{~cm} \text { to center }\end{array}$ & 100 & 46.7 & $8.91 \times 10^{-1}$ & $3.50 \times 10^{-1}$ & $8.06 \times 10^{-2}$ & $4.24 \times 10^{-2}$ & $1.47 \times 10^{-2}$ & $6.64 \times 10^{-3}$ & $3.62 \times 10^{-3}$ \\
\hline $\begin{array}{l}\text { \#32 } \\
\text { Top } \\
0-2.5 \mathrm{~cm} \text { in }\end{array}$ & 100 & 77.5 & 12.4 & 1.82 & $3.64 \times 10^{-1}$ & $1.94 \times 10^{-1}$ & $8.08 \times 10^{-2}$ & $3.95 \times 10^{-2}$ & $2.65 \times 10^{-2}$ \\
\hline $\begin{array}{l}\# 32 \text {, } \\
\text { Top, } \\
2.5 \mathrm{~cm} \text { to center }\end{array}$ & 100 & 32.3 & 4.21 & $2.96 \times 10^{-1}$ & $5.39 \times 10^{-2}$ & $2.55 \times 10^{-2}$ & $8.20 \times 10^{-3}$ & $3.51 \times 10^{-3}$ & $1.97 \times 10^{-3}$ \\
\hline $\begin{array}{l}\text { \#31 } \\
\text { Bottom } \\
0-2.5 \mathrm{~cm} \text { in }\end{array}$ & 100 & 100 & 17.5 & 1.94 & 1.01 & $2.00 \times 10^{-1}$ & $8.91 \times 10^{-2}$ & $2.64 \times 10^{-2}$ & $1.04 \times 10^{-2}$ \\
\hline $\begin{array}{l}\# 31 \\
\text { Middle } \\
0-2.5 \mathrm{~cm} \text { in }\end{array}$ & 100 & 80.0 & 12.8 & $7.55 \times 10^{-1}$ & $2.08 \times 10^{-1}$ & $1.15 \times 10^{-1}$ & $5.67 \times 10^{-2}$ & $3.14 \times 10^{-2}$ & $2.14 \times 10^{-2}$ \\
\hline $\begin{array}{l}\text { \#31 } \\
\text { Top } \\
0-2.5 \mathrm{~cm} \text { in }\end{array}$ & 100 & 92.0 & 8.72 & $5.57 \times 10^{-1}$ & $1.62 \times 10^{-2}$ & $9.43 \times 10^{-2}$ & $4.09 \times 10^{-2}$ & $2.18 \times 10^{-2}$ & $1.34 \times 10^{-2}$ \\
\hline $\begin{array}{l}\# 6 \\
\text { Impact area }\end{array}$ & & & 100 & 45.8 & 20.98 & 12.14 & 4.53 & 2.27 & 1.32 \\
\hline $\begin{array}{l}\# 36 \\
\text { Bottom } \\
0-2.5 \mathrm{~cm} \text { in }\end{array}$ & 100 & 68 & 11 & $3.24 \times 10^{-1}$ & $1.42 \times 10^{-1}$ & $9.22 \times 10^{-2}$ & $2.21 \times 10^{-2}$ & $8.30 \times 10^{-3}$ & $3.86 \times 10^{-3}$ \\
\hline $\begin{array}{l}\# 36 \\
\text { Botton } \\
2.5 \mathrm{~cm} \text { to center }\end{array}$ & 100 & 89.2 & 21 & 1.12 & $3.17 \times 10^{-1}$ & $1.70 \times 10^{-1}$ & $3.23 \times 10^{-2}$ & $1.45 \times 10^{-2}$ & $6.30 \times 10^{-3}$ \\
\hline $\begin{array}{l}\text { \#36 } \\
\text { Middle } \\
0-2.5 \mathrm{~cm} \text { in }\end{array}$ & 100 & 85.3 & $8.70 \times 10^{-1}$ & $5.01 \times 10^{-1}$ & $1.3 \times 10^{-1}$ & $7.5 \times 10^{-2}$ & $1.88 \times 10^{-2}$ & $7.58 \times 10^{-3}$ & $4.12 \times 10^{-3}$ \\
\hline $\begin{array}{l}\# 36 \\
\text { Middle } \\
2.5 \mathrm{~cm} \text { to center }\end{array}$ & 100 & 36.4 & 1.44 & $1.06 \times 10^{-1}$ & $3.45 \times 10^{-2}$ & $2.07 \times 10^{-2}$ & $7.22 \times 10^{-3}$ & $3.23 \times 10^{-3}$ & $1.78 \times 10^{-3}$ \\
\hline $\begin{array}{l}\# 36 \\
\text { Top } \\
0-2.5 \mathrm{~cm} \text { in }\end{array}$ & 100 & 62.4 & 5.65 & $1.51 \times 10^{-1}$ & $3.28 \times 10^{-2}$ & $1.78 \times 10^{-2}$ & $5.86 \times 10^{-3}$ & $2.29 \times 10^{-3}$ & $1.15 \times 10^{-3}$ \\
\hline $\begin{array}{l}\text { \#36 } \\
\text { Tap } \\
2.5 \mathrm{~cm} \text { to center }\end{array}$ & 100 & 32.1 & 2.05 & $9.46 \times 10^{-2}$ & $3.53 \times 10^{-2}$ & $2.43 \times 10^{-2}$ & $1.51 \times 10^{-2}$ & $1.24 \times 10^{-2}$ & $8.11 \times 10^{-4}$ \\
\hline
\end{tabular}


Examination of the as-filled canisters prompted the recommendation that the canisters be heated during filling. This was accomplished by insulating the cans during pouring, which resulted in noticeable improvements in quality as noted from external examination of the glass. Quantitative evaluation of fracturing in one of these insulated canisters has not yet been done.

The increase in surface area of glass in a canister subjected to a severe impact was also determined. Canister \#6 (an as-filled canister $0.4 \mathrm{~m}$ in dia with a $0.6-\mathrm{cm}$ carbon-steel wall and a hemispherical bottom) was dropped 7.62 meters. The canister was sampled in the zone of maximum impact. Sizing was done on the material from the impact zone and is compared in Figure $X .2$ with the as-filled $0.61-\mathrm{m}$ canister. The log-log scales are used only to cover the ranges of interest; no exponential relationship is necessarily implied. The calculated surface area of the material was $24.3 \mathrm{~cm}^{2} / \mathrm{g}$ after impact. Sedimentation size analysis showed that the $-10-\mu \mathrm{m}$ fraction was increased to $0.13 \%$ by impact $(1.3 \%$ at $-44 \mu \mathrm{m} \times 10 \%$ at $-10 \mu \mathrm{m})$. The severely impacted zone extends only $\sim 0.5 \mathrm{~m}$ from the impact point, and the rest of the glass in the canister appears to have suffered only minimal damage. 


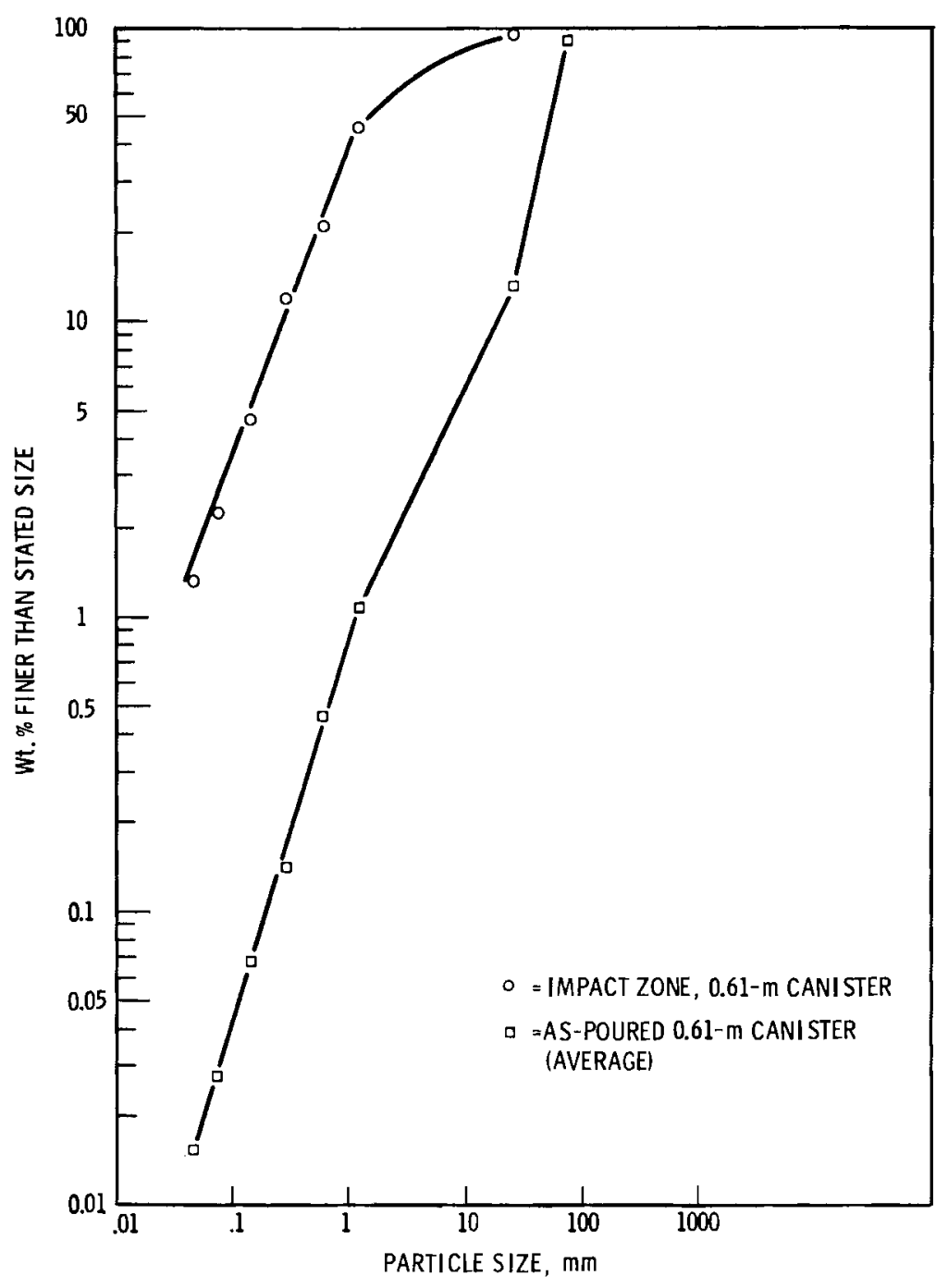

FIGURE X.2. Sieve Analys is Data for Two 0.61-m Canisters--One As-Poured and One After Impact Testing(a)

(a) Note $\log$ scales. 
• 


\section{QUALITY VERIFICATION}

W. L. Kuhn, L. M. Browne, Y. B. Katayama, J. M. Lukacs

This section addresses the characterization of "engineering-scale" glasses produced during vitrification equipment development and demonstration runs. The ultimate goal of quality verification is to document the reproducible and predictable aspects of homogeneous waste packaging. To this end, characterization methods are evolving to report quantitative data as a function of location in glass canisters that are suitable for constructing a data base amenable to statistical analyses and comparisons to process expectations.

Notable activities this year included characterization of products from continuous demonstration runs, evaluation of glass behavior in full-scale equipment, and continued evaluation of glass produced during the Waste Solidification Engineering Prototypes (WSEP) Program.

\section{SRP CERAMIC MELTER DEVELOPMENT RUNS}

A series of eight ceramic melter runs with simulated Savannah River waste were conducted to evaluate glass processing. About $6000 \mathrm{~kg}$ of glass was produced, filling four $0.61-\mathrm{m}$-dia by 2.90-m-long canisters. Figure XI.1 illustrates the variation of the process variables (melter electrode temperature and $\mathrm{fill}$ rate) and the product variables (densities and leach rates-Soxhlet method, $72 \mathrm{~h}$ at $99^{\circ} \mathrm{C}$ ) for the fourth through seventh runs. Glass from the four runs was all collected in canister number 52 . The density of the glass in canister 52 was practically constant; variability in the leach rate is thought to be within the precision of the Soxhlet method, with no correlation to process variations being found.

Optical examination of polished sections of cores taken from Canister \#52 reveals varying concentrations of finely divided crystals, as shown in Figures XI.2, XI.3, XI.4, and XI.5, corresponding to the $15-\mathrm{cm}, 61-\mathrm{cm}, 121-\mathrm{cm}$, and $152-\mathrm{cm}$ fill levels in the canister. No correlation between leach rate and crystal concentration was detected.

\section{SRP IN-CAN MELTER DEVELOPMENT RUNS}

Pilot-scale ICM runs were conducted to evaluate the melting characteristics of Savannah River frit/calcine mixtures. During run SRP-ICM-7 we put the furnace through a slow cool-down: $1050^{\circ} \mathrm{C}$ to $755^{\circ} \mathrm{C}$ over $5.7 \mathrm{~h}$, followed by an $11.5-\mathrm{h}$ hold at $755^{\circ} \mathrm{C}$. Previous experience with PNL glass compositions under such cooling has been satisfactory; however, the SRP glass (Frit 411, Composite SRP waste at 3:1) devitrified extensively.

Examination of SRP-ICM-7 glass samples revealed the presence of lithium-metasilicate $\left(\mathrm{Li}_{2} \mathrm{SiO}_{3}\right)$ at about $32 \mathrm{wt} \%$, plus an unidentified lesser phase. Microcracking was extensive. Subsequent laboratory remelts and anneals verified devitrification at $750^{\circ} \mathrm{C}$; at $1000^{\circ} \mathrm{C}$ no crystallization occurred. Soxhlet leach rates $\left(72 \mathrm{~h}\right.$ at $\left.100^{\circ} \mathrm{C}\right)$ for samples from SRP-ICM-7 were 1.2 to $1.5 \times 10^{-4} \mathrm{~g} / \mathrm{cm}^{2}-\mathrm{d}$--which is about $70 \%$ greater than for previous, similar SRP-ICM pilotscale runs, during which there was no hold at $750^{\circ} \mathrm{C}$. 

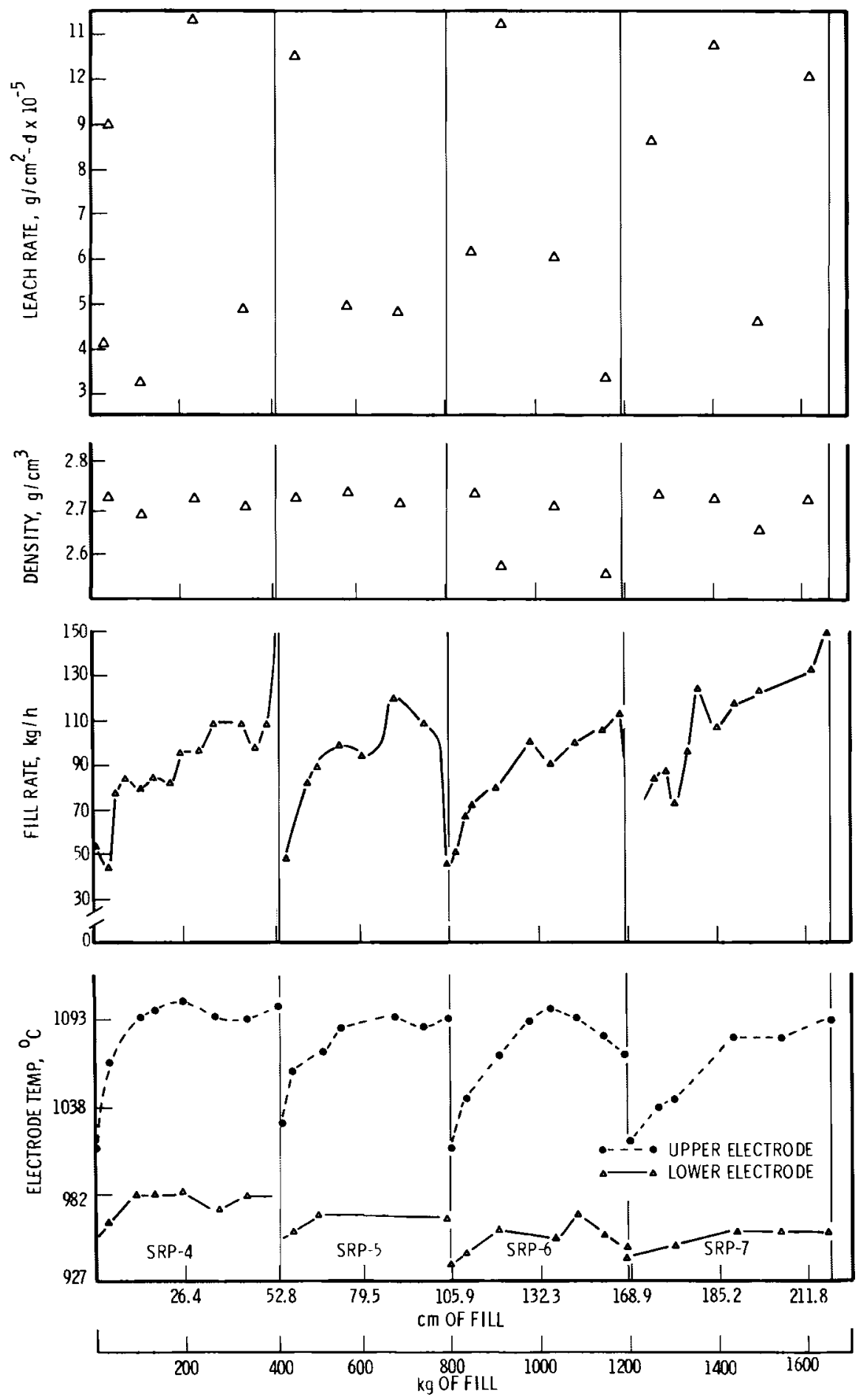

FIGURE XI.1 Process and Product Variables for Canister \#52, Which Was Filled in Runs SRP-4 through SRP-7 


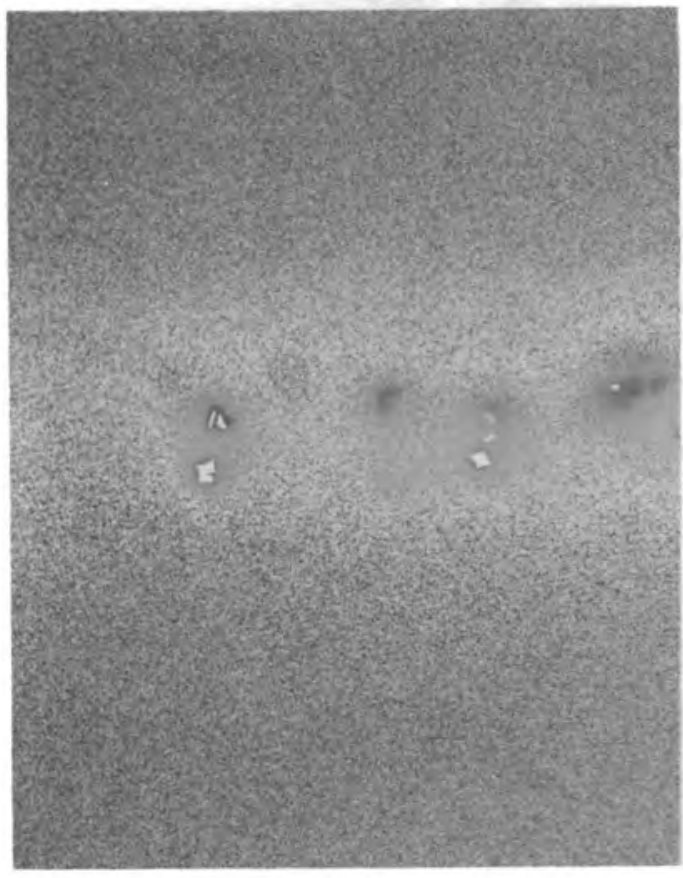

FIGURE XI.2. Micrograph of Glass Sample from Canister \#52 $15 \mathrm{~cm}$ Above Bottom

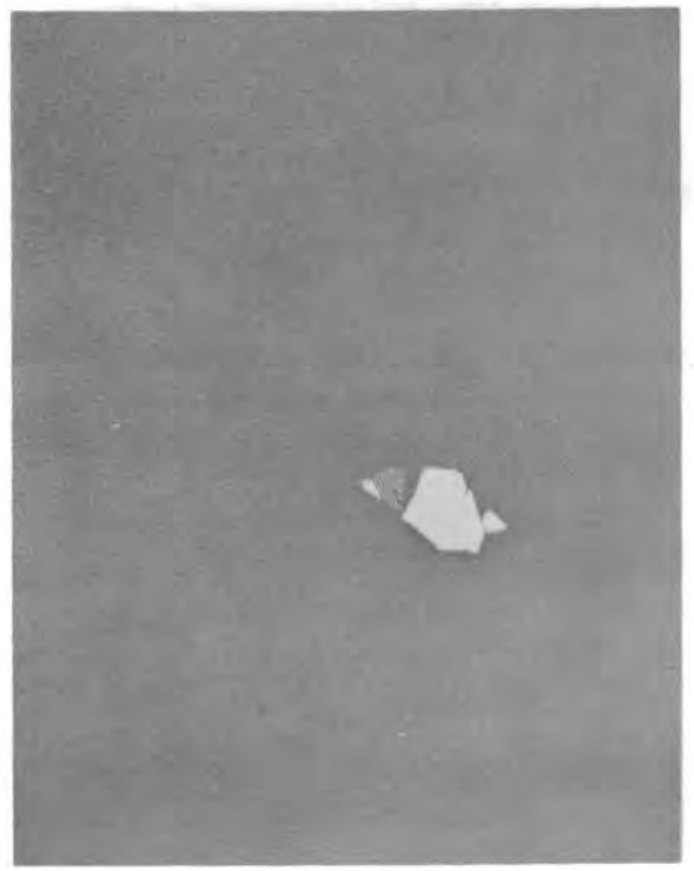

FIGURE XI.3. Micrograph of Glass Sample from Canister \#52 $61 \mathrm{~cm}$ Above Bottom 


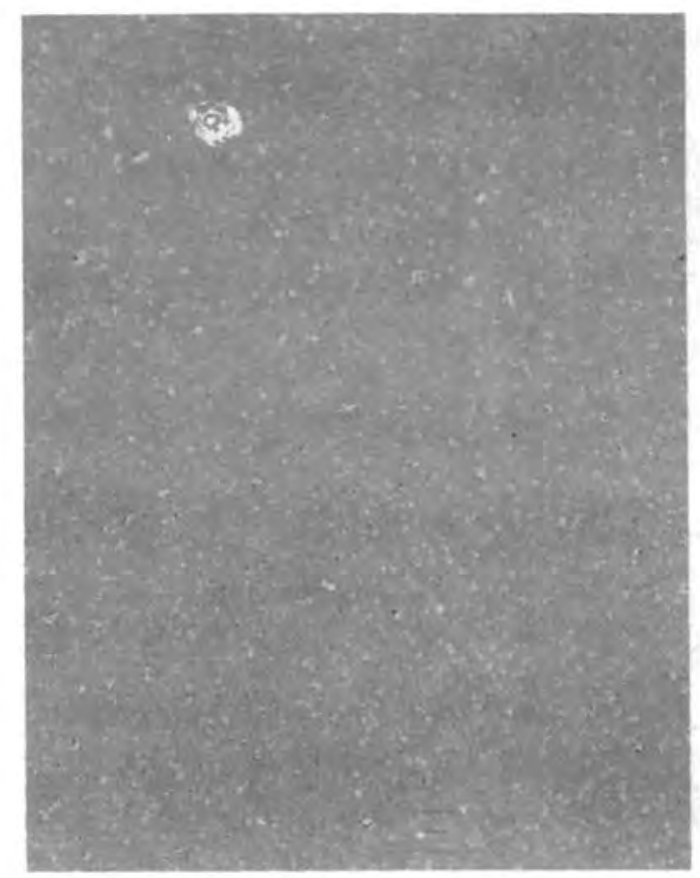

FIGURE XI.4. Micrograph of Glass Sample from Canister \#52 $122 \mathrm{~cm}$ Above Bottom

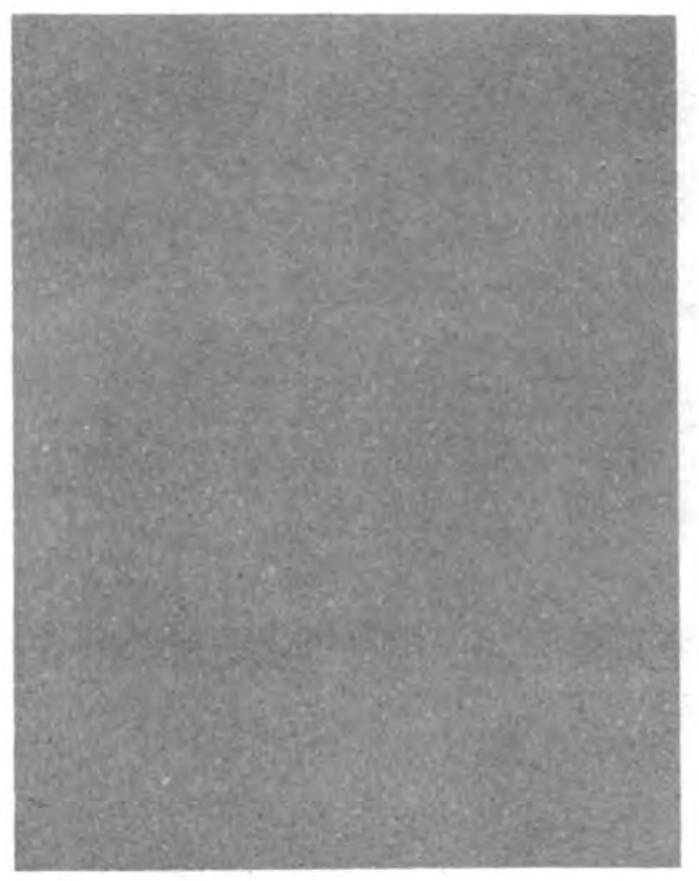

FIGURE XI.5. Micrograph of Glass Sample from Canister \#52 $152 \mathrm{~cm}$ Above Bottom 
A full-scale (61-cm-dia can) in-can melt of Savannah River glass was conducted to evaluate the resulting product. Product characterization is summarized in Tables XI.1 and XI.2. Table XI.2 is obtained from $x$-ray-fluorescence analyses of several transition metal elements; the concentrations were obtained as ratios of $x$-ray-fluorescence intensities with silicon intensity as a standard. Since a calibration for the glass samples has not been developed, the fluorescence ratios cannot be directly converted to atom-percent composition. Instead, the average ratio over the five samples is calculated for each element (see last row in Table XI.2) and used to normalize the fluorescence ratios for the various samples. The relative variation in concentration over the samples is thereby presented for each element.

$x$-ray-diffraction analys is confirms that roughly half of the crystalline material in Sample 1 is spinel; the remainder is not yet identified. The accumulation at the bottom indicates the settling of heavy crystallites (devitrification products or insolubles). Note that the Soxhlet leach rates do not correlate well with percent-crystallinity values.

\section{WSEP GLASS CHARACTERIZATION}

The leach rate of radioactive, simulated HLW borosilicate glass produced during run SS-12 of the WSEP Program has been reported previously after 8 mo (Mendel and MCElroy 1972) and $2.8 \mathrm{yr}$ (Mendel 1973) of storage. Additional samples were recently core-drilled from SS-12

TABLE XI.1. Product Characterization for SRP-ICM Run with 61-cm Can

\begin{tabular}{|c|c|c|c|c|}
\hline $\begin{array}{l}\text { Sample } \\
\text { No. }\end{array}$ & $\begin{array}{l}\text { Location, } \mathrm{cm} \\
\text { above bottom }\end{array}$ & $\begin{array}{l}\text { Density, } \\
\mathrm{g} / \mathrm{cm}^{2}\end{array}$ & $\begin{array}{c}\text { Soxhlet Leach Rate, } \\
\mathrm{g} / \mathrm{cm}^{2}-\mathrm{d} \\
\end{array}$ & $\begin{array}{c}\text { Crystallinity, } \\
\text { vol\% }\end{array}$ \\
\hline 1 & 0 to 33 on center & 2.75 & $1.6 \times 10^{-4}$ & 46 \\
\hline 2 & 30 at outer surface & 2.64 & $2.2 \times 10^{-4}$ & 8 \\
\hline 3 & 63 at outer surface & 2.64 & $8.6 \times 10^{-5}$ & 2 to 3 \\
\hline 4 & 109 at outer surface & 2.62 & $1.6 \times 10^{-4}$ & 2 to 3 \\
\hline 5 & 155 at outer surface & 2.64 & $9.7 \times 10^{-5}$ & 2 to 3 \\
\hline
\end{tabular}

TABLE XI.2. Chemical Analyses for SRP-ICM Run with 61-cm Can

\begin{tabular}{|c|c|c|c|c|c|}
\hline \multirow{2}{*}{$\begin{array}{c}\text { Element } \\
\text { Sample No. }\end{array}$} & \multicolumn{5}{|c|}{ Relative Concentrations } \\
\hline & Fe & AT & $\mathrm{Cr}$ & $M n$ & $\mathrm{Ni}$ \\
\hline 1 & 1.79 & 2.01 & 1.68 & 1.82 & 1.57 \\
\hline 2 & 0.87 & 0.76 & 1.01 & 0.80 & 0.71 \\
\hline 3 & 0.72 & 0.71 & 0.72 & 0.78 & 0.97 \\
\hline 4 & 0.73 & 0.79 & 0.64 & 0.77 & 0.99 \\
\hline 5 & 0.89 & 0.72 & 0.96 & 0.83 & 0.76 \\
\hline $\begin{array}{l}\text { Unnormalized } \\
\text { Average Ratio } \\
\text { Compared to Si }\end{array}$ & 8.278 & $0.139^{(a)}$ & 0.377 & 1.419 & 0.708 \\
\hline
\end{tabular}

(a) Ti secondary target; all others are for Ba secondary target. 
after 8.4-yr storage, $3 \mathrm{yr}$ of which was at temperatures of $400^{\circ}$ to $450^{\circ} \mathrm{C}$. Radiation exposure during the storage period is estimated to be $2.2 \times 10^{11} \mathrm{rads} / \mathrm{g}$. Leach tests were conducted in a Paige extractor at $25^{\circ} \mathrm{C}$ with deionized water.

The results of the leach tests based on $\mathrm{Cs}^{137}$ are compared in Figure XI.6 to the 8-mo and 2.8 -yr results. Through $175 \mathrm{~d}$ of leaching, no significant changes from the 8 -mo-old glass data are seen, which demonstrates significant stability of glass castings in thermal and radiation environments.

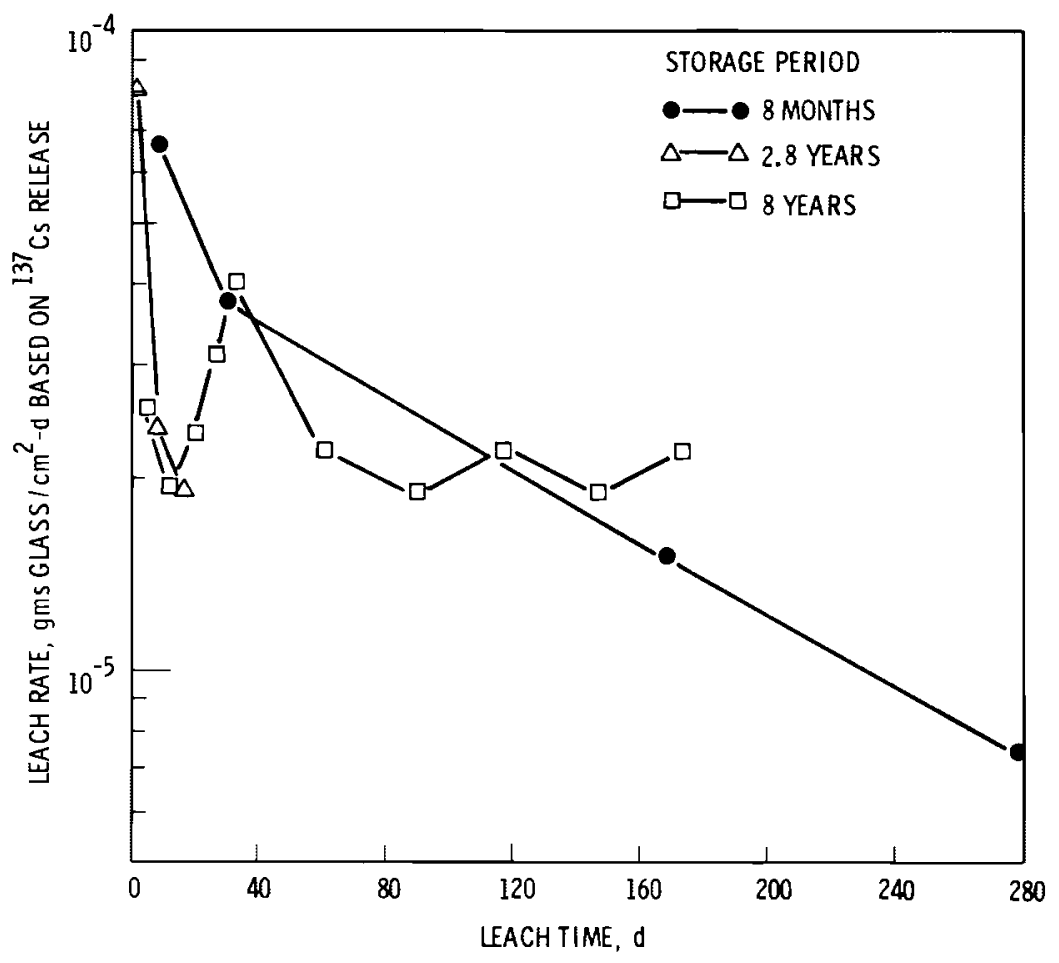

FIGURE XI.6. Leach Rate Based on ${ }^{137}$ Cs Release of Borosilicate Glass Vitrified During WSEP Run SS-12 After Storage Periods Indicated 


\section{REFERENCES}

Aaron, W. S., T. C. Quinby and E. H. Kobisk. 1978. Cermet High Level Waste Forms. ORNL/TM-6404, 0ak Ridge National Laboratory, Oak Ridge, Tennessee.

Be11, M. J. 1973. ORIGEN--The ORNL Isotope Generation and Depletion Code. ORNL-4628, Oak Ridge National Laboratory, Oak Ridge, Tennessee.

Bibler, N. E., and J. A. Kelley. 1978. Effect of Internal Alpha Irradiation on Borosilicate Glass Containing Savannah River Plant waste. DP-1482, Savannah River Laboratory, Aiken, South Carolina.

Brandstetter, A., et al. 1979. Quarterly Technical Progress Report for April-June 1979. PNL-2885-3, Pacific Northwest Laboratory, Richland, Washington.

Chapman, C. C. 1976. Experience With a Joule-Heated Ceramic Melter While Converting Simulated High-Level Waste to Glass. BNWL-2071, Pacific Northwest Laboratory, Richland, Washington.

Chapman, C. C., et al. 1979. Vitrification of Hanford Wastes in a Joule-Heated Ceramic Melter and Evaluation of Resultant Canisterized Product. PNL-2904, Pacific Northwest Laboratory, Richland, Washington.

Ewing, R. C., and R. F. Haaker. 1979. "The Metamict State: Radiation Damage in Crystalline Materials." In Proceedings of the International Symposium on Ceramics in Nuclear Waste Management, eds. T. D. Chikalla and J. E. Mende1, CONF-790420, D0E-TIC.

Floyd, S. B., and W. H. Engelleitner. 1967. "The Theory and Practice of Disc Balling." In Proceedings of 10th Biennial Conference of the Institute for Briquetting and Agglomeration. Albuquerque, New Mexico.

Gray, W. J. 1976. Volatility of a Zinc Borosilicate Glass Containing Simulated High-Level Radioactive Waste. BNWL-2111, Pacific Northwest Laboratory, Richland, Washington.

Katayama, Y. B. 1979. Spent LWR Fuel Leach Tests. PNL-2982, Pacific Northwest Laboratory, Richl and, Washington.

Knapp, W. R., and E. R. Smith. 1962. Method for Forming Balls from Thermo-Plastic Materials. U.S. Patent 3,254,979 assigned to Corning Glass Works by U.S. Patent Office, Washington, D.C.

Lutze, W. 1979. "Glass and Glass-Ceramic Waste Form Characterization." In Proceedings of Conference on Scientific Basis for Nuclear Waste Forms. ed. G. J. McCarthy, Plenam Press, New York, New York.

McCarthy, G. J. 1977. Nucl. Technol. 32:92.

McElroy, J. L., et al. 1979a. Quarterly Progress Report - Research and Development Activities - Waste Fixation Program, October Through December 1977. PNL-2265-4, Pacific Northwest Laboratory, Richland, Washington.

MCElroy, J. L., et al. 1979b. Ouarterly Progress Report - Research and Development Activities - High-Level Waste Immobilization Program: July Through September 1978. PNL-2999-3, Pacific Northwest Laboratory, Richland, Washington.

MCElroy, J. L., et al. 1979c. Quarterly Progress Report - Research and Development Activities - High-Level Waste Immobilization Program: April Through June 1978. PNL-2999-2, Pacific Northwest Laboratory, Richland, Washington.

McElroy, J. L., et al. 1979d. Quarterly Progress Report - Research and Development Activities - High-Level Waste Immobilization Program: January Through March 1979. PNL-3050-1, Pacific Northwest Laboratory, Richland, Washington. 
McElroy, J. L., et al. 1979e. Quarterly Progress Report - Research and Development Activities - High Level Waste Immobilization Program: April Through June 1979. PNL-3050-2, Pacific Northwest Laboratory, Richland, Washington.

Mellinger, G. B., and L. A. Chick. 1979. "Compositional Effects on Waste Glass Properties." In Proceedings of the International Symposium on Ceramics in Nuclear Waste Management, eds. T. D. Chikalla and J. E. Mendel, CONF-790420, DOE-TIC.

Mende 1, J. E., and J. L. McElroy. 1972. Waste Solidification Program, Volume 10: Evaluation of Solidified Waste Products. BNWL-1666, Pacific Northwest Laboratory, Richland, Washington.

Mendel, J. E. 1973. "Measurements on Core-Drilled Samples." In Quarterly Progress Report Research and Development Activities - Waste Fixation Program, December 1972 Through March 1973, ed. A. M. Platt, p. 24. BNWL-1741, Pacific Northwest Laboratory, Richland, Washington.

Mende1, J. E., et al. 1975. A Program Plan for Comprehensive Characterization of Solidified High-Level Wastes. BNWL-1940. Pacific Northwest Laboratory, Richland, Washington.

Mende 1, J. E., et al. 1977. Annual Report on the Characteristics of High-Level Waste Glasses. BNWL-2252, Pac if ic Northwest Laboratory, Richland, Washington.

Mendel, J. E. 1978. The Storage and Disposal of Radioactive Waste as Glass in Canisters. PNL-2764, Pacific Northwest Laboratory, Richland, Washington.

Moore, E. L. 1978. Interim Report: Commercial Waste Packaging Studies, Task 2 High-Level Waste Package Acceptance Criteria Study. RHO-ST-10, Atomic's International Division, Rockwe 11 Hanford Operations, Richland, Washington.

Ross, W. A., et a1. 1978. Annual Report on the Characterization of High-Level Waste Glasses. PNL-2625. Pacific Northwest Laboratory, Richland, Washington.

Ross, W. A., J. M. Rusin and J. L. McElroy. 1979. "Processes for Production of Alternative Waste Forms." In Proceedings of the Symposium on Waste Management 1979, ed. R. Post, University of Arizona, Tucson, Arizona.

Ross, W. A., et al. 1979. "A Comparison of Glass and Crystalline Waste Materials." In Proceedings of the International Symposium on Ceramics in Nuclear Waste Management, eds. T. D. Chikalla and J. E. Mende T, CONF-790420, D0E-TIC.

Rusin, J. M. 1978. Applicability of Alternative Waste Forms for Immobilization of Alternative Fuel Cycle Wastes. PNL-2775, Pacific Northwest Laboratory, Richland, Washington.

Rusin, J. M., et al. 1978. Multibarrier Waste Forms, Part I: Development. PNL-2668-1, Pacific Northwest Laboratory, Richland, Washington.

Rusin, J. M., R. 0. Lokken and J. W. Wald. 1979a. "Characterization and Evaluation of Multibarrier Nuclear Waste Forms." In Proceedings of the International Symposium on Ceramics in Nuclear Waste Management, eds. T. D. Chikalla and J. E. Mende 1, CONF-790420, DOE-TIC.

Rusin J. M., R. 0. Lokken and J. W. Wald. 1979b. Multibarrier Waste Forms, Part II: Characterization and Evaluation. PNL-2668-2, Pacific Northwest Laboratory, Richland, Washington.

Simonen, F. A., J. A. Griffiths and M. J. Thurgood. 1978. "Analysis of a Canister Closure Design by Damage Tolerance Concepts." ASME 78-PUP-108. Paper presented at the Joint ASME/CSME Pressure Vessels and Piping Conference, June 25-29, Montreal, Canada.

Simonen, F. A., and S. C. Slate. 1977. "Creep Analys is of Canisters of Radioactive Waste Vitrification." Trans. of the Am. Nuc. Soc. 27:259-260.

Slate, S. C., and W. A. Ross. 1977. High-Level Radioactive Waste Glass and Storage Canister Design. BNWL-SA-6379, Pacific Northwest Laboratory, Richland, Washington. 
Slate, S. C., et al. 1979. "Stresses and Cracking in High-Level Waste Glass." In Proceedings of the Conference on High-Level Radioactive Solid Waste Forms. NUREG/CP-0005, Nuclear Regulatory Commission, Washington, D.C.

Slate, S. C., and R. F. Maness. 1978. "Corrosion Experience in Nuclear Waste Processing at Battelle-Northwest." Materials Performance 17:13+.

Turcotte, R. P., and J. W. Wald. 1978. Devitrification Behavior in a Zinc Borosilicate Nuclear Waste Glass. PNL-2247, Pacific Northwest Laboratory, Richland, Washington.

VanEcho, J. A., and F. H. Simonen. 1978. "Strength of 304L Stainless Steel and Inconel 601 at Temperat ures Above $1000^{\circ} \mathrm{C} . "$ "ASME 78-PUP-31. Paper presented at the Jo int ASME/CSME Pressure Vessels and Piping Conference, June 25-29, Montreal, Canada.

Wald, J. W., and J. H. Westsik, Jr. 1979. "Devitrification and Leaching Effects in HLW Glass--Comparison of Simulated and Fully Radioactive Waste Glass." In Proceedings of Conference on Ceramics in Nuclear Waste Management, eds. T. D. Chikalla and J. E. Mende 1, CONF-790240, DOE-TIC.

Weber, W. J., et al. 1979. "Radiation Damage in Vitreous and Devitrified Simulated Waste Glass." In Proceedings of the International Symposium on Ceramics in Nuclear Waste Management, eds. T. D. Chikalla and J. E. Mendel, CONF-790420, DOE-TIC.

Westcott, R. I., and S. C. Slate. 1979. "Vitrification of High Level Wastes: A Review of the Computer Thermal Analyses for Storage Canisters." Paper presented at the American Institute of Chemical Engineers' 87th National Meeting in Boston, Massachusetts, August 1979. Also: PNL-SA-7917, Pacific Northwest Laboratory, Rich1and, Washington.

Westsik, Jr., J. H., and R. P. Turcotte. 1978. Hydrothermal Reactions of Nuclear Waste Solids - A Preliminary Study. PNL-2759, Pacific Northwest Laboratory, Richland, Washington. 
. 
$\checkmark$ 
APPENDIX

REPOSITORY CONSEQUENCE ANALYSES 
A methodology has been developed for analyzing the potential radiologic dose consequences from deep geologic repositories that would result from a scenario involving groundwater penetration into a repository, leaching of the radionuclides from the waste, and transport of the nuclides to the biosphere, where they may interact with humans (Burkholder et al. 1975). This methodology is now being applied in two Office of Nuclear Waste Isolation (ONWI) programs. The Systems Study on Engineered Barriers Program application will provide a perspective on what benefit may be obtained by reduced leach rates, more durable containers, or increased sorption of nuclide ions. This benefit is measured in terms of incremental dose reduction achieved by barrier improvement. The Ore Bodies Comparison Program application involves applying the same methodology to naturally occurring uranium ore deposits in order to determine the potential dose consequences from ore deposits relative to those from a man-made repository.

\section{SYSTEMS STUDY ON ENGINEERED BARRIERS}

The development and characterization of waste forms, containers and other engineered barriers destined for use in the isolation of nuclear waste in deep geologic repositories has progressed to the point where there are several options and combinations of barrier systems that are available to help assure safe disposal of nuclear wastes. However, a rigorous bas is has not yet been developed to select materials or to define required characteristics. This analys is is an attempt to develop an initial perspective on what is needed in order to establish that basis. The intent of the analysis is to roughly determine what incentives exist for providing highly durable engineered barriers for the isolation of radioactive waste in a deep geologic repository, based on what effect, if any, the engineered barrier may have on the ultimate potential dose to humans.

The highest risk path from the storage site through the geosphere to the biosphere is assumed to be the "leach incident pathway." (a) The geologic isolation system ideally provides barriers to the process by two general means: 1) containment of the waste for a length of time sufficient to allow the hazardous nuclides to decay to innocuous levels, such that unrestricted release to the environment presents no unacceptable radiological hazard; or 2) limiting the rate of nuclide release to the biosphere so that nuclide concentrations in the constantly renewed local surface water and air never exceed acceptable limits.

(a) To this point in the analysis, the "leach incident pathway" has been assumed to be the highest risk pathway. However, a human intrusion event such as a waste well penetration near the repository may be the limiting scenario and is being investigated at this writing. 
The actual repository system will provide protection by using some effective balance of these two means. The available system components that provide these means for protection can be reduced to: 1) the waste form, 2) the containment package, and 3) the geology (including hydrology).

The radionuclide inventory used in the analysis is one-fifth of the total for the spent, unreprocessed fuel (no-recycle case) accumulated in the U.S. through the year 2050 that was used in the Draft Commercial Waste Management Generic Environmental Impact Analys is (DOE/EIS-0046-D) (1979). The assumption was that there would be five operating repositories, each containing an equal fraction of the total U.S. spent-fuel accumulation.

The geosphere transport model simulates the release of radionuclides from a repository through contact and leaching by flowing groundwater, through subsequent transport of the nuclides in the groundwater (including the effects of convection, sorption, and radioactive decay), and through ultimate release of the nuclides to the surface water (lake or river). In order to simplify the analysis, a multitude of parameters were reduced to terms representing the net effect of several more complex phenomena.

The release rate of nuclides into the flowing groundwater (source term) is a constant rate approximation ( $\% / y r)$ of what may in reality be a more complex release function that can be more explicitly modeled after in-situ performance analyses have progressed sufficiently. A parameter representing the combined durability of the engineered barrier containment function and the stability (or integrity) of the surrounding geology is the vilay (years) in release-incident in itiation, measured from the date of repository closure. The major hydrologic parameters are dispersivity, groundwater flow rates, and total pathlength to the biosphere. These are functions of geologic media factors such as porosity, permeability, net hydraulic head, and gradient and fracture patterns. For this analysis, these parameters have been reduced to groundwater travel time (pathlength/flow velocity) and a net dispersion coefficient. Output data of the geosphere model is the input data for the biosphere model. The biosphere model (Denham et al. 1973; Soldat, Robinson and Baker 1974; Baker, Hoenes and Soldat 1975) predicts the radiation dose to humans from the nuclide release to surface waters via several pathways-including direct ingestion of water, aquatic foods and irrigated food products, as well as irradiation from shoreline deposition and swimming. Food chain reconcentration/accumulation effects are included.

The methodology was applied to one generic site and, to a limited extent, to a more realistic reference site utilizing measured and estimated parameters. The parameters for the generic site were chosen to maximize any incentive for providing a long-lived container or other means of delaying groundwater contact with and leaching from the waste matrix. Sorption properties of the surrounding geologic media were taken from BNWL-1927 (Burkholder et al. 1975). The results of the generic analysis are summarized in Figure A.1. Note that delaying the release initiation for up to $10^{6} \mathrm{yr}$ has no effect upon the potential dose even for very short groundwater travel times of 10 and 100 years. This is because the dose-controlling nuclide is ${ }^{226} \mathrm{Ra}$ generated by decay from the very long-lived ${ }^{238} \mathrm{U}$ and ${ }^{234} \mathrm{U}$. The groundwater travel times shown in Figure $A .1$ are much shorter than would reasonably be expected for any 


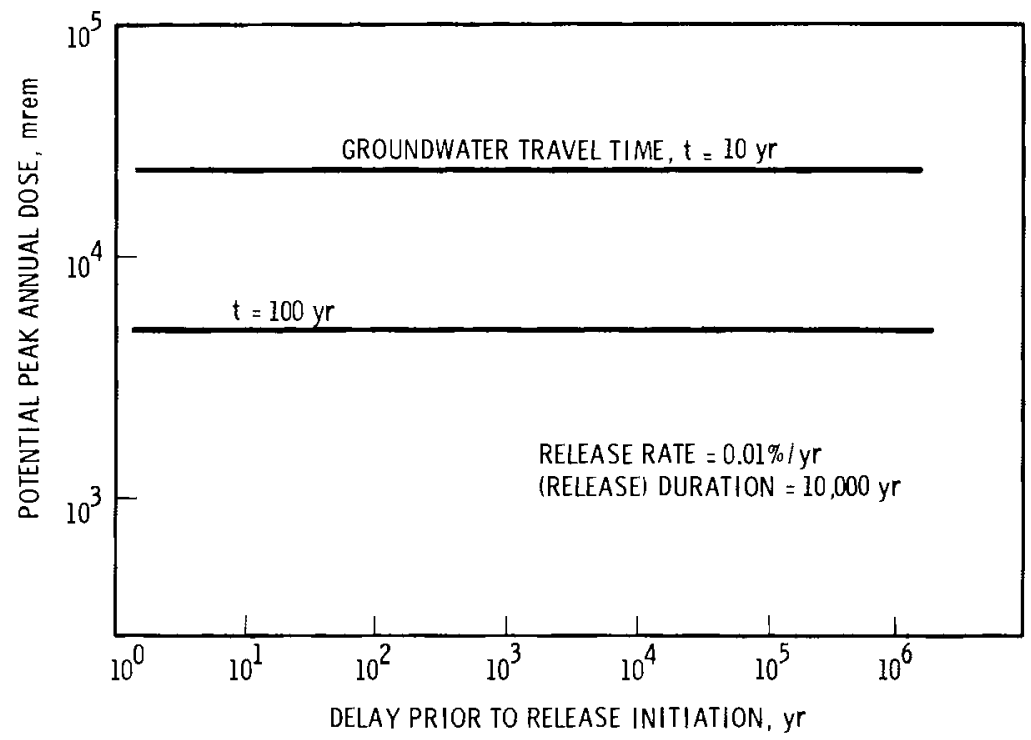

FIGURE A.1. Potential Maximum Dose Rate Versus Delay in Release Initiation for Generic Site

site that would be selected as a repository; they were chosen as parameters in order to determine how small this parameter would have to be in order to observe any effect due to the delay in release-event initiation. The relative difference in resultant dose predicted for the $10-y r$ and 100-yr groundwater travel times in Figure A.1 is the result of a much greater time and distance dispersion of the ${ }^{226} \mathrm{Ra}$ daughter product in the 100 -yr case, which is in turn caused by the large sorption differences among members of the decay chain.

Figure A.2 shows the effect of the release rate on the potential dose from the generic site with a groundwater travel time of $100 \mathrm{yr}$ after a release-initiation delay of $10^{6}$ years. The graph in Figure A.2 indicates that even after a delay of one million years, the release rate of nuclides from the waste matrix into the groundwater has a significant effect upon the potential dose from the scenario. The dose-controlling nuclide for short-release durations (fast release), ${ }^{129} \mathrm{I}$, is rapidly reduced in dose contribution with decreasing release rate until it ceases to dominate the potential dose at a release duration of about 20 years. The dashed line in Figure A.2 indicates the continuing ${ }^{121_{I}}$ potential dose trend. The release rate is seen to have almost no effect upon the potential dose from the ${ }^{226} \mathrm{Ra}$ until the release duration exceeds $10^{5}$ years. After this point, the ${ }^{226}$ Ra dose potential decreases rapidly. This behavior is typical of what has been observed (from modeling) for the transport of nuclides that are the products of complex decay chains. The different sorption properties of the members of the decay chain disperse the members greatly during transport, and the duration of the release into the groundwater has little effect on the ultimate release of decay products until the release duration approaches the order of magnitude of the sorption distribution (in years) of all members of the chain.

This effect may also be observed in some limited results from the reference site analysis. The groundwater travel time for the reference site $(40,000 \mathrm{yr})$ and site sorption 


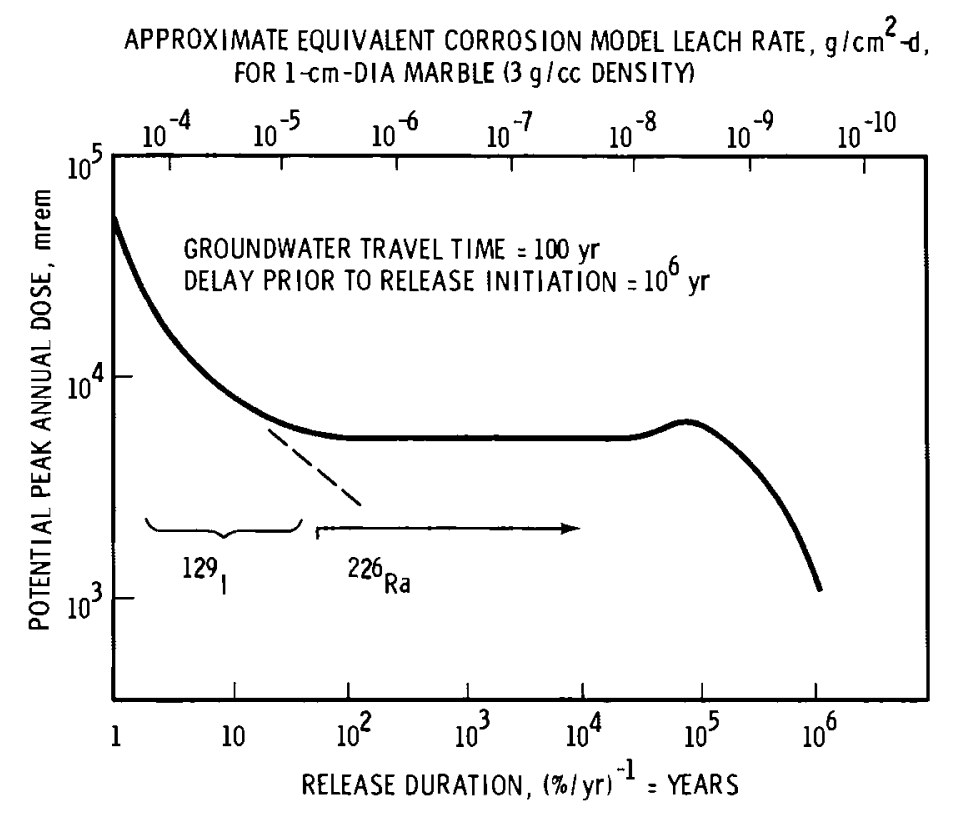

FIGURE A.2. Potential Maximum Dose Rate Versus Release Rate for Generic Site

characteristics are much more realistic than are those for the generic site, and are probably closer to those that would be representative of a site considered for a repository. The graph in Figure $A .3$ indicates a nearly linear reduction in the ${ }^{129}$ I potential dose with decreasing release rate (absolute linearity would exist if the effects of dispersion were not considered). This is because the iodine is not a product of decay chains and, even on the time scale of $F i g-$ ure $A .3$, has an essentially infinite half-life. The ${ }^{226} \mathrm{Ra}$, however, is the product of the decay chain ${ }^{238} \mathrm{U} \rightarrow\left({ }^{234} \mathrm{Th} \rightarrow{ }^{234} \mathrm{~Pa}\right) \rightarrow{ }^{234} \mathrm{U} \rightarrow{ }^{230} \mathrm{Th} \rightarrow{ }^{226} \mathrm{Ra}$, and the release duration has very little effect upon the potential ${ }^{226} \mathrm{Ra}$ dose until it exceeds $10^{5}$ years.

For the sites analyzed, the graphs in Figures $A .2$ and A.3 suggest that after a maximum, sustained-release rate equivalent of less than $1.0 \% / \mathrm{yr}$ is attained, very little benefit is realized until the release rate is reduced further--to less than $10^{-3} \% / \mathrm{yr}$. This lower rate would be equivalent to a right-cylindrical waste form with a density of $3 \mathrm{~g} / \mathrm{cm}^{3}$, a diameter of $0.3 \mathrm{~m}$, and a simple corrosion-model net leach rate of $10^{-6} \mathrm{~g} / \mathrm{cm}^{2}-\mathrm{d}$. For a spherical particle diameter of $1 \mathrm{~cm}$, the equivalent leach rate would be about $4 \times 10^{-8} \mathrm{~g} / \mathrm{cm}^{2}-\mathrm{d}$. The above are observations based on very limited results and are not considered to be conclusions. More conclusive results will be available later in this effort, after the methodology is applied to fairly well defined reference sites. All quantitative values presented here are intended for methodology illustration only, and should not be put to any other use. 


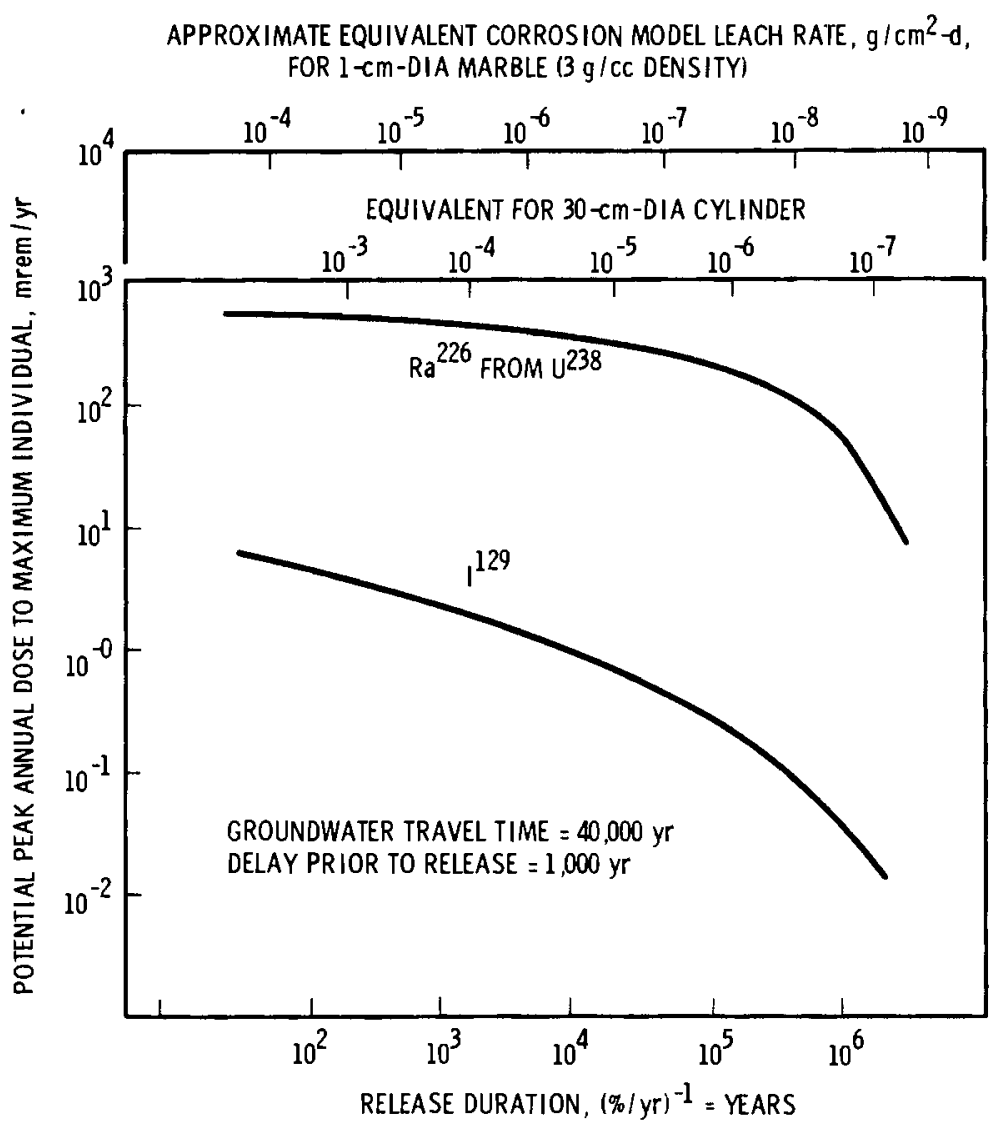

FIGURE A.3. Potential Maximum Dose Rate Versus Release Rate for a Reference Salt Site

\section{ORE BODIES COMPARISON}

It has been suggested that one general criterion for deep geologic repositories containing spent fuel is that they should represent no greater radiological risk than that posed by naturally occurring uranium ore deposits. While the tools for performing a classic risk analysis on a geologic repository or an ore deposit are not yet available, a methodology has been developed for estimating the potential radiologic consequences resulting from groundwater intrusion, leaching, and nuclide transport scenarios (Burkholder et al. 1975). This methodology has been applied in a very limited manner to predict the potential radioactive release from ore bodies in order to compare these calculations with those performed in the past for spent-fuel repositories (GEIS). As a check on the ore bodies release estimates, the calculated results from the ore bodies analysis have been compared to actual measured surface-water concentrations of radioactive material that apparently had its origin in natural ore bodies.

Descriptive data for two major ore deposits were gathered from available literature and from discussions with United States Geological Survey experts in Grand Junction, Colorado. Potential dose consequences from these ore bodies were then calculated using the same methodology as was applied in limited analyses of spent-fuel repositories. The two ore deposits are 
Granite Mountain, Wyoming and the Rossing deposit in South West Africa. These two sites were picked because of their large uranium inventories. The Granite Mountain deposit is a widely distributed deposit, and has a lower specific uranium concentration than does the Rossing deposit, which is more compact. The characteristics of the Granite Mountain deposit are assumed to be those present nearly $60 \mathrm{million}$ years ago. It has been determined that some granite samples from the Granite Mountain region have lost nearly $80 \%$ of the uranium originally contained in them---this uranium having been leached away during the last $60 \mathrm{million}$ years. The Rossing deposit of South West Africa was chosen because of its high specific activity: between 30 and 130 times that of Granite Mountain. The deposit is in the very dry Namib Desert. The annual rainfall there is about an inch per year. The deposit is near the edge of the Khan River Basin, but the river contains water only when there is runoff from the infrequent rains. Thus, the leaching of uranium from the deposit is slow. Pertinent data regarding these two deposits and the reference repository are summarized in Tables A.1 and A.2.

Data was also obtained from uranium concentrations in surface streams in order to evalute whether actual releases from natural deposits provide potentially high dose consequences. Fix (1956) listed several of these values; the highest small-stream value reported was $32 \mathrm{ppb}$ in Bishop Creek, Montana, and the highest river concentration was $4 \mathrm{ppb}$ in the Sevier River in Utah. It may be significant that various types of mining operations had been initiated in the general area of these streams before these data were collected. These values served as input for the biosphere model to estimate the potential dose consequences resulting from these surface concentrations.

TABLE A.1. Nuclide Inventories for Ore Bodies and Reference Repository

\begin{tabular}{|c|c|c|c|}
\hline \multirow{3}{*}{ Nuclide } & \multicolumn{3}{|c|}{ 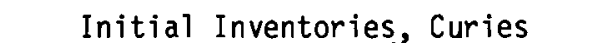 } \\
\hline & Reference & Granite & Rossing \\
\hline & Repository & Mountain & Deposit \\
\hline $238 \mathrm{U}$ & $2.4 \mathrm{E} 4$ & $3.4 \mathrm{E} 7$ & $1.9 \mathrm{E} 5$ \\
\hline${ }^{234} U$ & $1.3 \mathrm{E} 5^{(a)}$ & $3.4 \mathrm{E7}$ & $1.9 \mathrm{E} 5$ \\
\hline${ }^{230} \mathrm{Th}$ & 2.9E1 & $3.4 \mathrm{E} 7$ & 1.9E5 \\
\hline${ }^{226} \mathrm{Ra}$ & 2. $9 \mathrm{E}-1$ & $3.4 \mathrm{E7}$ & $1.9 E 5$ \\
\hline${ }^{129} \mathrm{I}$ & $2.5 \mathrm{E} 3$ & -- & -- \\
\hline
\end{tabular}

(a) Includes ingrowth from 238 pu during first 1000 years.

TABLE A.2. System Parameters for Ore Bodies and Reference Repository

\begin{tabular}{|c|c|c|c|c|}
\hline Site & $\begin{array}{c}\text { Groundwater } \\
\text { Velocity, } \\
\text { m/yr } \\
\end{array}$ & $\begin{array}{c}\text { Migration } \\
\text { Pathlength, } \\
\text { km } \\
\end{array}$ & $\begin{array}{c}\text { Groundwater } \\
\text { Travel Time, } \\
\text { yr } \\
\end{array}$ & $\begin{array}{l}\text { Leach Rate, } \\
\text { fraction/yr }\end{array}$ \\
\hline $\begin{array}{l}\text { Reference } \\
\text { Repository }\end{array}$ & $1.3 \mathrm{E} 0$ & $5.6 \mathrm{E} 1$ & $4.3 \mathrm{E} 4$ & $4.0 \mathrm{E}-3-1.0 \mathrm{E}-6$ \\
\hline Granite Mtn. & $2.2 \mathrm{E}-1$ & $1.0 \mathrm{E} 1-3.2 \mathrm{E} 1$ & $4.5 \mathrm{E} 4-1.5 \mathrm{E} 5$ & $1.3 \mathrm{E}-7-1.3 \mathrm{E}-8$ \\
\hline Rossing & $1.1 \mathrm{EO}$ & $3.2 \mathrm{EO}$ & $3.0 \mathrm{E} 3$ & $1.0 E-7$ \\
\hline
\end{tabular}


The potential annual maximum-individual dose for the repository and the two reference ore bodies as well as for selected surface waters are summarized in Figure A.4. The peak releases in all cases occur over such long periods of time (thousands to millions of years) that they can be considered as chronic, constant environmental conditions.

The calculated potential dose to a maximum individual from the generic repository ranges from a high of about $700 \mathrm{mrem} / \mathrm{yr}$ to a $1 \mathrm{ow}$ of about $80 \mathrm{mrem} / \mathrm{yr}$ for the range of parameters used. This compares with a range of 1200 to $120 \mathrm{mrem} / \mathrm{yr}$ calculated dose from the Granite Mountain deposit and a single calculation of $5 \mathrm{mrem} / \mathrm{yr}$ from the Rossing deposit. The potential dose to the maximum individual calculated for the surface waters was based on the assumption that ${ }^{226} \mathrm{Ra}$ was in decay equilibrium with the reported uranium concentrations in the streams. The calcu1 ated potential dose to the maximum individual for the various streams were:

- Bishop Creek = 30,000 mrem $/ \mathrm{yr}$;

- Sevier River = $4000 \mathrm{mrem} / \mathrm{yr}$;

- average Wyoming surface water $=600 \mathrm{mrem} / \mathrm{yr}$.

The per-capita general population dose from the Wyoming average surface-water concentrations would be in the range of 100 to $200 \mathrm{mrem} / \mathrm{yr}$.

Based only upon these limited calculations, it appears from the standpoint of potential radiological consequences that the spent-fuel repository and the large bodies are quite comparable. In fact, apparent releases from some ore deposits (based upon measured uranium concentration in surface streams) probably exceed what would be considered "acceptable" releases from a man-made repository.

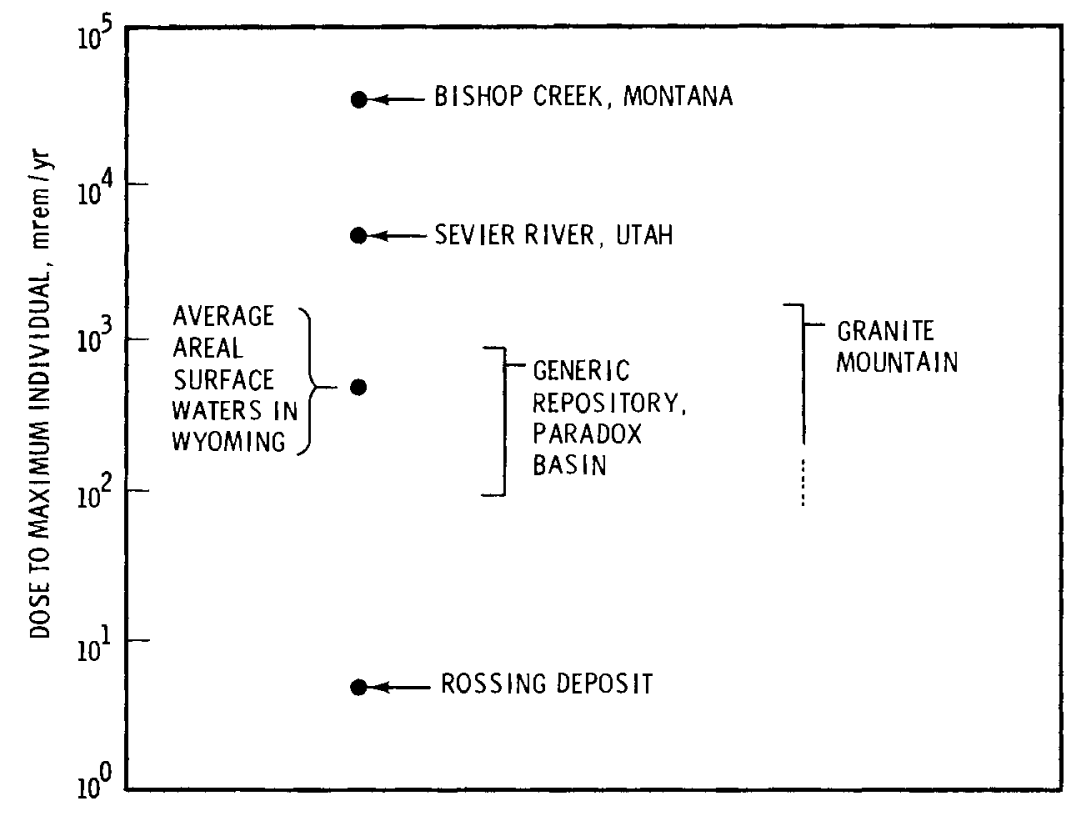

FIGURE A.4. Summary of Potential Radiological Consequence Results 
It should be noted, however, that the limited work to date in no way forms a rigorous basis for any criteria that relate spent-fuel repository requirements to naturally occurring uranium ore bodies.

It is also worth noting that the calculated releases from the Granite Mountain deposit span the measured average value of nuclide concentrations in Wyoming surface waters (Figure A.4). 


\section{REFERENCES}

Baker, D. A., G. R. Hoenes and J. K. Soldat. 1975. "F00D - An Interactive Code to Calculate Internal Radiation Doses from Contaminated Food Products." BNWL-SA-5525A, Pacific Northwest Laboratory, Richland, Washington.

Burkholder, H. C., et al. 1975. "Incentives for Partitioning High-Level Waste." Nuclear Technology 31:202, 1976. Also: BNWL-1927, Pacific Northwest Laboratory, Richland, Washington.

Denham, D. H., et al. 1973. Radiological Evaluation for Advanced Waste Management Studies. BNWL-1764. Pacific Northwest Laboratory, Richland, Washington.

Draft Environmental Impact Statement: Management of Commercially Generated Radioactive Waste. 1979. DOE/EIS-0046-D, DOE-TIC.

Fix, P. F. 1956. "Geochemical Prospecting for Uranium by Sampling Ground and Surface Waters." In Proceedings of Conference on Peaceful Uses of Atomic Energy, Geneva, Switzerland, p. 788.

Soldat, J. K., N. M. Robinson and D. A. Baker. 1974. Models and Computer Codes for Evaluating Environmental Radiation Doses. BNWL-1754, Pacific Northwest Laboratory, Richland, Washington. 
No. of

Copies

\section{UNITED STATES}

A. A. Churm

DOE Chicago Patent Division

9800 South Cass Avenue

Argonne, IL 60439

R. E. Cunningham

Deputy Director for Fuels and

Materials

Nuclear Regulatory Commission

Silver Springs, MD 20910

Assistant Director for Radioactive Waste Management Branch

NRC Division of Materials and Fuel Cycle Facility Licensing

Washington, DC 20545

D. M. Rohrer

United States Nuclear Regulatory

Commission

Washington, DC 20555

John Martin

United States Nuclear Regulatory

Commission

Washington, DC 20555

W. G. Belter

DOE Division of Biomedical and

Environmental Research

Earth Sciences Branch

Washington, DC 20545

W. A. Brobst

DOE Division of Environmental Control Technology

Washington, DC 20545

W. E. Mott

DOE Division of Environmental Control Technology

Washington, DC 20545

R. B. Chitwood

DOE Division of Nuclear Power

Development

Washington, DC 20545

T. C. Chee

DOE Office of Nuclear Waste Management Washington, DC 20545

C. R. Cooley

DOE Office of Nuclear Waste Management Washington, DC 20545
No. of

Copies

Sheldon Meyers

DOE Office of Nuclear Waste Management Washington, DC 20545

R. G. Romatowski

DOE Office of Nuclear Waste Management Washington, DC 20545

C. A. Heath

DOE Office of Nuclear Waste Management Washington, DC 20545

G. Oertel

DOE Office of Nuclear Waste Management Washington, DC 20545

A. F. Perge

DOE Office of Nuclear Waste Management Washington, DC 20545

D. L. Vieth

DOE Office of Nuclear Waste Management Washington, DC 20545

R. D. Walton DOE Office of Nuclear Waste Management Washington, DC 20545

J. Neff, Program Manager

Department of Energy

Columbus Program office

$505 \mathrm{King}$ Avenue

Columbus, $\mathrm{OH} 43201$

J. B. Whitsett

DOE Idaho Operations Office

P.0. Box 2108

Idaho Falls, ID 83401

John Van Cleve

DOE Oak Ridge Operations Office

P.0. Box $X$

Oak Ridge, TN 37830

E. S. Goldberg

DOE Savannah River Operations Office

P.0. Box A

Aiken, SC 29801

324 DOE Technical Information Center

A. P. Roeh, Manager

Exxon Nuclear

Idaho Corporation

P. 0. Box 2800

Idaho Falls, ID 83401 
No. of

Copies

J. R. Berreth

Exxon Nuclear

Idaho Corporation

P. 0. Box 2800

Idaho Falls, ID 83401

R. A. Brown

Exxon Nuclear

Idaho Corporation

P. 0. Box 2800

Idaho Falls, ID 83401

C. A. Hawley

Exxon Nuclear

Idaho Corporation

P. 0. Box 2800

Idaho Falls, ID 83401

D. A. Knecht

Exxon Nuclear

Idaho Corporation

P. 0. Box 2800

Idaho Falls, ID 83401

Exxon Nuclear

I daho Corporation

(File Copy)

P. 0. Box 2800

Idaho Falls, ID 83401

M. D. McCormack

E.G. \& G. Idaho, Inc.

P.0. Box 1625

Idaho Falls, ID 83401

W. C. Seymour

E.G. \& G. Idaho, Inc.

P.0. Box 1625

Idaho Falls, ID 83401

R. A. Buckham

Allied-General Nuclear Service

P.0. Box 847

Barnwe 11, SC 29812

A. Williams

Allied-General Nuclear Service

P.0. Box 847

Barnwe 11, SC 29812

Keith Flynn

Argonne National Laboratory

9700 South Cass Avenue

Argonne, IL 60439

J. L. Jardine

Argonne National Laboratory

9700 South Cass Avenue

Argonne, IL 60439
No. of

Copies

M. M. Steindler/L. E. Trevorrow Argonne National Laboratory 9700 South Cass Avenue

Argonne, IL 60439

J. M. Batch

Battelle Memorial Institute

505 King Ave.

Columbus, $\mathrm{OH} 43201$

Wayne Carbiener

Battelle Memorial Institute

505 King Ave.

Columbus, $\mathrm{OH} 43201$

J. D. Duguid

Battelle Memorial Institute

505 King Ave.

Columbus, $\mathrm{OH} 43201$

R. E. Heineman

Battelle Memorial Institute

505 King Ave.

Columbus, $\mathrm{OH} 43201$

Battelle Memorial Institute Office of Nuclear Waste Isolation

Attn: Beverly Rawles

$505 \mathrm{King}$ Avenue

Columbus, $\mathrm{OH} 43201$

J. Kircher

Office of Nuclear Waste Isolation Battelle Memorial Institute

505 King Ave.

Columbus, $\mathrm{OH} 43201$

Don Moak

Battelle Memorial Institute

505 King Ave.

Columbus, $\mathrm{OH} 43201$

Ken Yates

Battelle Memorial Institute

505 King Ave.

Columbus, $\mathrm{OH} 43201$

Brookhaven National Laboratory

Reference Section

Information Division

Upton, NY 11973

Paul W. Levy

Brookhaven National Laboratory Upton, NY 11973

M. Ste inberg

Brookhaven National Laboratory Upton, NY 11973 
No. of

Copies

Combustion Division

Combustion Engineering, Inc.

Windsor, CT 06095

B. Adams

Corning Glass Works

Technical Staffs Division

Corning, NY 14830

E. Vejvoda, Director

Chemical Operations

Rockwe 11 International

Rocky Flats Plant

P.0. Box 464

Golden, CO 80401

J. L. Crandall

E. I. duPont DeNemours and Company

Savannah River Laboratory

Aiken, SC 29801

Jim Howe 1

E. I. duPont DeNemours and Company

Savannah River Laboratory

Aiken, SC 29801

H. L. Hull

E. I. duPont DeNemours and Company

Savannah River Laboratory

Aiken, SC 29801

R. G. Garvin

E. I. duPont DeNemours and Company

Savannah River Laboratory

Aiken, SC 29801

D. L. McIntosh

E. I. duPont DeNemours and Company

Savannah River Laboratory

Aiken, SC 29801

J. A. Kelley

E. I. duPont DeNemours and Company

Savannah River Laboratory

Aiken, SC 29801

M. D. Boersma

E. I. duPont DeNemours and Company

Savannah River Laboratory

Aiken, SC 29801

Robert Maher

E. I. duPont DeNemours and Company

Savannah River Laboratory

Aiken, SC 29801

S. Mirschak

E. I. duPont DeNemours and Company

Savannah River Laboratory

Aiken, SC 29801
No. of

Copies

J. K. Okeson

E. I. duPont DeNemours and Company

Savannah River Laboratory

Aiken, SC 29801

M. S. Plodinec

E. I. duPont DeNemours and Company Savannah River Laboratory

Aiken, SC 29801

A. S. Jennings

E. I. duPont DeNemours and Company

Savannah River Laboratory

Aiken, SC 29801

Leon Meyers

E. I. duPont DeNemours and Company

Savannah River Laboratory

Aiken, SC 29801

R. F. Williams

Electric Power Research Institute

3412 Hillview Avenue

P.0. Box 10412

Palo Alto, CA 94301

H. Henning

Electric Power Research Institute

$3412 \mathrm{Hillview}$ Avenue

P.0. Box 10412

Palo Alto, CA 94301

Environmental Protection Agency

Technology Assessment Division (AW-559)

Office of Radiation Programs

Washington, DC 20460

R. G. Barnes

General Electric Company

175 Curtner Avenue (M/C 858)

San Jose, CA 95125

L. H. Brooks

Gulf Energy and Environmental Systems

P.0. Box 81608

San Diego, CA 92138

D. C. Fulmer

Savannah River Operations Office

P.0. Box A

Aiken, SC 29801

3 Los Alamos Scientific Laboratory (DOE)

P.0. Box 1663

Los Alamos, NM 87544

C. J. Kershner

Monsanto Research Corporation Mound

Laboratory

P.0. Box 32

Miamisburg, $\mathrm{OH} 45342$ 
No. of

Copies

John Pomeroy

Technical Secretary

National Academy of Sciences

Committee of Radioactive Waste

Management

National Research Council

2101 Constitution Avenue

Washington, DC 20418

Stewart Farber

New England Power Company

280 Melrose Street

Providence, Rhode Is land 02901

2 J. P Duckworth

Plant Manager

Nuclear Fuel Services, Inc.

P.0. Box 124

West Valley, NY 14171

J. G. Cline, General Manager

NYS Energy Research and Dèvelopment Authority

230 Park Avenue, Rm 2425

New York, NY 10017

2 Oak Ridge National Laboratory (DOE)

Central Research Library

Document Reference Section

P.0. Box $X$

Oak Ridge, TN 37830

E. H. Kobisk

Solid State Division

Oak Ridge National Laboratory

Oak Ridge, TN 37830

G. J. McCarthy

N. Dakota State Univeristy

Department of Chemistry

Fargo, ND 58102

Professor Guna Salvaduray

Materials Engineering

San Jose State University

San Jose, CA 95192

D. R. Anderson

Sandia Laboratories

Albuquerque, NM 87107

J. K. Johnstone

Sandia Laboratories

Albuquerque, NM 87107

W. Weart

Sandia Laboratories

Albuquerque, NM 87107

J. Sivinski

Sandia Laboratories

Albuquerque, NM 87107
No. of

Copies

J. 0. Blomeke

Union Carbide Corporation (ORNL)

Chemical Technology Division

P.0. Box $Y$

Oak Ridge, TN 37830

R. E. Bl anco

Union Carbide Corporation (ORNL)

Chemical Technology Division

P.0. Box $Y$

Oak Ridge, TN 37830

E. Newman

Union Carbide Corporation (ORNL)

Chemical Technology Division

P.0. Box $Y$

Oak Ridge, TN 37830

A. L. Lotts

Union Carbide Corporation (ORNL)

Chemical Technology Division

P.0. Box $Y$

Oak Ridge, TN 37830

W. J. Lackey

Union Carbide Corporation (ORNL)

Chemical Technology Division

P.0. Box $Y$

Oak Ridge, TN 37830

T. Lindemer

Union Carbide Corporation (ORNL)

Chemical Technology Division

P.0. Box Y

Oak Ridge, TN 37830

D. E. Ferguson

Union Carbide Corporation (ORNL)

Chemical Technology Division

P.0. Box $Y$

Oak Ridge, TN 37830

H. W. Godbee

Union Carbide Corporation (ORNL)

Chemical Technology Division

P.0. Box Y

Oak Ridge, TN 37830

W. C. McClain

Union Carbide Corporation (ORNL)

Chemical Technology Division

P.0. Box $Y$

Oak Ridge, TN 37830

R. A. Beall

U. S. Department of Interior Bureau of Mines

Albany Research Center

$1450 \mathrm{~W}$. Queen Avenue

Albany, OR 97321 
D. B. Stewart

U. S. Department of Interior 959 National Center Geological Survey

Reston, Virginia 22092

R. G. Post

College of Engineering

University of Arizona

Tucson, AZ 85721

S. E. Logan

Los Alamos Technical Associates, Inc.

P.0. Box 410

Los Alamos, NM 87544

\section{FOREIGN}

2 International Atomic Energy Agency

Kärtner Ring 11

P.0. Box 590

A-1011, Vienna, AUSTRIA

Rene Amavis

EURATOM

Health Physics Division

29, Rue Aldringer

Luxembourg, BELGIUM

G. G. Strathdee

Atomic Energy of Canada, Ltd.

W.N.R.E. Pinawa, Manitoba

ROE ILO

CANADA

M. Toml inson

Director of Chemistry and Materials Science Division

Atomic Energy of Canada Ltd.

Whiteshell Nuclear Research

Establishment

Pinawa, Manitoba, CANADA

K. D. B. Johnson

Atomic Energy Research Establishment, Harwe 11, Didcot,

Berks, ENGLAND

J. A. C. Marples

Atomic Energy Research Establishment

Harwe 11, Didcot,

Berks, ENGLAND

D. W. Clelland

United Kingdom Atomic Energy Authority Risley, ENGLAND
P. J. Regnaut

Centre d'Etudes Nucleaires de

Fontenay-aux Roses

Boite Postale 6

92 - Fontenay-aux Roses

FRANCE

Dr. P. G. Alfredson

Chief, Chemical Technology Division Australian Atomic Energy Commission Research Establishment

Lucas Heights, New South Wales, 2232

Library

Studsvik Energiteknik $A B$

S-611 0lNykoping

SWEDEN

Bundesministerium für Forschung und Technologie

Stres semannstrasse?

5300 Bonn

WEST GERMANY

Center for Atomic Energy

Documentation (ZAED)

Attn: Dr. Mrs. Bell

P. 0 . Box 3640

$7500 \mathrm{Kar}$ lsruhe

WEST GERMANY

Hans W. Levi

Hahn-Meitner Institut

1 Berlin 39

Glienickerstr. 100

WEST GERMANY

E. R. Merz

Institut für Chemische

Technologie

Kernforschungsanloge Julich

GmbH

D517 Julich

Postfach 365

Federal Republic

WEST GERMANY

R. Bonniaud

Center de Marcoule

B.P. 170

30200 Baguols-Sur-Ceze

FRANCE

C. Sombret

Centre de Marcoule

B.P. 170

30200 Baguols-Sur-Ceze

FRANCE 
No. of

Copies

FOREIGN

F. Laude

Centre de Marcoule

B.P. 170

30200 Baguo ls-Sur-Ceze

FRANCE

2 H. Krause

Kernforschungszentrum Karlsruhe $\mathrm{GmbH}$ (KfK)

Postfach 3640

D7500 Kar lsruhe

WEST GERMANY

R. V. Amalraj

C.W.M.F. Project

P.0. Kalpakkam

Chingleput Dist.

Tamil Nadu, INDIA

N. S. Sunder Rajan

Bhabha Atomic Research Centre

Goverment of India

Hall No. 5

Trombay

Bombay 85

INDIA

Dr. Piero Risoluti,

AGIP NUCLEARE

C/O COMB Casaccia

C.P. 2400

Rome

ITALY

F. Gera

CHEN

CSN Casaccia L.I.S.

C.P. 2400,00100

Rome

ITALY

S. Tashiro

Japan Atomic Energy Research Institute

Environmental Safety Research

Laboratory

1-1-13, Shibashi

Minatopku, Tokyo

JAPAN

\section{ONSITE}

4 DOE Richland Operations Office

P. A. Craig

H. E. Ransom

M. W. Shupe

M. J. Zamorsk i
No. of

Copies

12 Rockwell Hanford Operations

H. Babad

R. A. Deju

R. J. Gimera

J. D. Kaser

E. J. Kosiancic

M. J. Kupfer

C. M. Manry

J. H. Roecker

W. W. Schulz

M. J. Smith

D. D. Wodrich

File copy

3 Exxon Nuclear Company

S. J. Beard

Joint Center for Graduate Study

J. Cooper

2 UNC Nuclear Industries, Inc.

T. E. Dabrowski

A. E. Engler

West inghouse Hanford Company

A. G. Blasewitz

129 Pacific Northwest Laboratory

S. M. Barnes

W. J. Bjorklund

H. T. Blair

W. F. Bonner

D. J. Bradley

A. Brandstetter

R. A. Brouns

J. B. Brown, Jr.

J. L. Buelt

R. L. Bunnell

L. A. Chick

T. D. Chikalla

M. O. Cloninger

C. M. Devary

R. D. Dierks

J. W. Finnigan

W. J. Gray

M. S. Hanson

A. J. Haverfield

M. H. Henry (3)

O. F. Hill

L. K. Holton

J. H. Jarrett 
No. of

Copies

ONSITE

Y. B. Katayama

W. S. Kelly

R. S. Kemper

D. E. Know 1 ton

C. A. Knox

D. K. Kreid

W. L. Kuhn

D. E. Larson

R. P. Marshall

S. A. McCullough

J. L. McElroy (3)

G. B. Mellinger

J. E. Mende 1

F. A. Miller

T. A. Nelson

R. E. Nightingale

C. R. Palmer

L. L. Petkus

A. M. Platt

D. L. Prezbindowski (2)

F. P. Roberts

W. A. Ross (61)

J. M. Rusin

D. H. Siemens

S. C. Slate

R. T. Treat

R. P. Turcotte (2)

H. H. Van Tuyl

J. W. Voss

J. W. Wald/W. E. Weber

J. H. Westsik, Jr.

L. D. Williams

W. K. Winegardner

Technical Information (5)

Publishing Coordination YO (2) 
i

, 